JOSEMBERG DA SILVA BAPTISTA

\title{
REPERCUSSÕES MORFOLÓGICAS NO TIMO DE RATOS JOVENS SUBMETIDOS À DESNUTRIÇÃO PROTÉICA E À RENUTRIÇÃO PRECOCEMENTE CORRIGIDA
}

Dissertação apresentada ao Instituto de Ciências Biomédicas da Universidade de São Paulo, para obtenção do Título de Mestre em Ciências (Ciências Morfofuncionais). 
JOSEMBERG DA SILVA BAPTISTA

\section{REPERCUSSÕES MORFOLÓGICAS NO TIMO DE RATOS JOVENS SUBMETIDOS À DESNUTRIÇÃO PROTÉICA E À RENUTRIÇÃO PRECOCEMENTE CORRIGIDA}

Dissertação apresentada ao Instituto de Ciências Biomédicas da Universidade de São Paulo, para obtenção do Título de Mestre em Ciências.

Área de concentração: Ciências Morfofuncionais

Orientador: Prof. Tit. Edson Aparecido Liberti 
DADOS DE CATALOGAÇÃO NA PUBLICAÇÃO (CIP)

Serviço de Biblioteca e Informação Biomédica do

Instituto de Ciências Biomédicas da Universidade de São Paulo

reprodução não autorizada pelo autor

Baptista, Josemberg da Silva.

Repercussões morfológicas no timo de ratos jovens submetidos à desnutrição protéica e à renutrição precocemente corrigida / Josemberg da Silva Baptista. -- Săo Paulo, 2008.

Orientador: Edson Aparecido Liberti.

Dissertação (Mestrado) - Universidade de São Paulo. Instituto de Ciências Biomédicas. Departamento de Anatomia. Área de concentração: Ciências Morfofuncionais. Linha de pesquisa: Morfologia do timo.

Versão do título para o inglês: Morphologic repercussions in young rat thymus submitted to protein undernourishment and early corrected renourishment.

Descritores: 1. Timo 2. Desnutrição 3. Renutrição 4. Análise morfoquantitativa 5. Ultra-estrutura I. Liberti, Edson Aparecido II. Universidade de São Paulo. Instituto de Ciências Biomédicas. Programa de Pós Graduação em Ciências Morfofuncional III. Título. 
UNIVERSIDADE DE SÃO PAULO

INSTITUTO DE CIÊNCIAS BIOMÉDICAS

\begin{abstract}
Candidato(a): $\quad$ Josemberg da Silva Baptista.
Título da Dissertação: $\quad$ Repercussões morfológicas no timo de ratos jovens submetidos à desnutrição protéica e à renutrição precocemente corrigida.
\end{abstract}

Orientador(a): $\quad$ Edson Aparecido Liberti.

A Comissão Julgadora dos trabalhos de Defesa da Dissertação de Mestrado, em sessão pública realizada a ........... .........
( ) Aprovado(a)
( ) Reprovado(a)

Examinador(a):

Assinatura:

Nome:

Instituição:

Examinador(a): Assinatura:

Nome:

Instituição:

Presidente: Assinatura:

Nome:

Instituição: 


\section{Certificado}

Certificamos que o protocolo registrado sob $n^{\circ} 031$ nas fls. 44 do livro 2 para uso de animais em experimentaçāo, sob a responsabilidade de Edson Aparecido Liberti Coordenador(a) da Linha de pesquisa "Repercussões morfológicas no timo de ratos jovens submetidos à desnutrição protéica e à renutrição precocemente corrigida" do qual participou(aram) o(s) alunos Josemberg da Silva Baptista, está de acordo com os Principios Éticos de Experimentação Animal adotado pelo Colégio Brasileiro de Experimentação Animal (COBEA) e foi aprovado pela COMISSÃO DE ÉTICA EM EXPERIMENTAÇÃO ANIMAL (CEEA) em 17.04.2007.

São Paulo, 17 de abril de 2007.
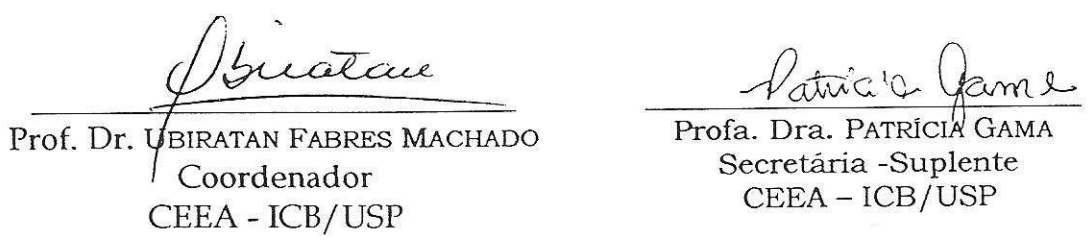
Dedico esta obra aos meus queridos pais: Ana Nazira da Silva Baptista e José Baptista Sobrinho, Exemplo de fortaleza, esperança e persistência. 


\section{AGRADECIMENTOS}

A Deus por permitir a minha existência com saúde e prover sempre excelentes pessoas ao meu redor, como as citadas ao longo desse texto.

A minha família, Ana Nazira da Silva Baptista, José Baptista Sobrinho, José Baptista Sobrinho Júnior, Luana da Silva Baptista Arpini, André Fiorin Arpini e Bernardo Baptista Arpini, por sempre me encorajar e acreditar, suprindo-me de esperança e vontade.

Ao amigo William Paganini Mayer, por estar presente dia após dia, compartilhando os sonhos, os medos, os erros e as angústias, que ao longo desta jornada passamos, e que você grande amigo, me ajudou incondicionalmente a superá-las.

Aos caríssimos amigos, Carlos Eduardo Seyfert e família, Dorival Terra Martini, Flávia de Oliveira, Flávio Silva Tampelini, Leonardo Ferreira Liberti, Mateus Elias Pacheco, Ricardo Jacob Hessell, Ricardo Bragança de Vasconcellos Fontes, pela ajuda inestimável, ensinamentos, e por todos os momentos vividos. Devo-lhes minha eterna e sincera gratidão.

A minha tão querida e amada namorado Eloah da Silva Prado, por toda sua paciência, compreensão, dedicação irrestrita, amor e carinho demonstrados a todo o momento.

A família Gardim, Silva e Cândido, por terem me acolhido com tanto amor e carinho. 
Ao Orientador e amigo, Professor Dr. Edson Aparecido Liberti, pelo caráter e ideais que tanto me ensinaram. Por fazer germinar em mim a ciência e a arte, conduzindo esta orientação com tamanha sabedoria, fazendo-me galgar mais este degrau.

A Professora Dra. Sílvia de Campos Boldrini, pela presteza, inteligência e serenidade no qual conduziu seus ensinamentos a mim.

Ao Grande Mestre Professor Dr. Fernando Musso, pela inspiração, orientações valiosas, e por fazer do aprendizado não um trabalho, mas um contentamento, que tanto me incentivou na busca do saber.

Ao Professor Dr. Rogério Albuquerque Azeredo, pela amizade, precioso estímulo, oportunidade e irrestrita dedicação que me ensinou a fazer o melhor, e assim, fazê-lo cada vez melhor.

Ao Professor Dr. Hildegardo Rodrigues, que com tamanha retidão, direcionou com rigor e sabedoria as suas orientações a mim.

Ao Professor Dr. Dulcino Tose, pelo estimado suporte e dedicação prestada em minha formação.

Aos demais Professores do Departamento de Morfologia da Escola Superior de Ciências da Santa Casa de Misericórdia de Vitória, Dr. Cláudio Piras, Dr. Romildo Rabbi, Dr. José Alberto Barreira Sarmento, por sempre contribuírem de maneira exemplar em meu desenvolvimento como Anatomista.

A Professora Dra. Luciana Sogame, Coordenadora do curso de Fisioterapia da Escola Superior de Ciências da Saúde da Santa Casa de Misericórdia de Vitória, por encorajar, acreditar e sempre incentivar meu ingresso na carreira acadêmica.

Aos demais Professores do Curso de Fisioterapia da Escola Superior de Ciências da Saúde da Santa Casa de Misericórdia de Vitória, pelo primoroso empenho na minha formação como Fisioterapeuta. 
Aos Professores que constituíram a Banca de qualificação, Dr. Pedro Primo Bombonato, Dra. Sílvia de Campos Boldrini e Dr. Eduardo Pompeu, pela valiosa colaboração com conselhos e sugestões proferidas nesta ocasião.

Aos grandes amigos, Breno Zanetti Melotti, Carlos Chagas, Fabiana Bosser, Gustavo Monti Rocha, Vinícius Bis Lima, Vinícius Milanesi e Vitor Bride, por mesmos distantes, acreditarem e fornecerem um apoio tão estimado.

Aos Professores das disciplinas cursadas no mestrado: Dr. Cláudio Antônio Ferraz de Carvalho, Dr. Edson Aparecido Liberti, Dr. Luis Ronaldo Picosse, Dra. Miriam Krasilchik, Dr. Pedro Primo Bombonato, Dr. Rainer Guilherme Haetinger, Dr. Richard Halti Cabral e Dra. Silvia de Campos Boldrini, por toda sabedoria transmitida.

Ao Professor Dr. Newton Sabino Canteras, Coordenador do Programa de Pós-Graduação em Ciências Morfofuncionais do Departamento de Anatomia do Instituto de Ciências Biomédicas da Universidade de São Paulo.

Ao Professor Dr. Jackson Cioni Bittencourt, Chefe do Departamento de Anatomia do Instituto de Ciências Biomédicas da Universidade de São Paulo.

Aos demais Professores do Departamento de Anatomia do Instituto de Ciências Biomédicas da Universidade de São Paulo, por contribuírem de uma maneira ou de outra na realização deste trabalho.

Aos queridos colegas do Laboratório de Anatomia Funcional Aplicado à Clínica e Cirurgia Ágatha Pawlowski de Oliveira, Aline Gonçalves, Allan Benedito Bonani, Bruna Cecília Caixeta de Oliveira, Cibele Maciel de Miranda, Diana Alves de Oliveira, Isabela de Ugo Luques, Letícia Nogueira da Gama de Souza, Lynda Tamayo Arango, Lucilene Ferreira Luiz, Luiz Henrique Silveira Rodrigues, Marcelo Arthur Cavalli, Marcelo Ferreira Calderon, Márcio Cristófaro, Maritza Alves de Sousa Coura, Mateus Elias Pacheco, Milton de Siqueira Ferreira Anzaloni Saavedra, Paulo Alexandre Galvanini, Paulo Henrique de Matos Alves, Regina de Sousa Bolina, 
Rogério Cruz de Oliveira, Sabrina Caixeta de Oliveira, Simone Piccoli, Thiago Habacuque Silva Souza, Ticiana Sidorenko de Oliveira Capote, Valquíria Barboza Mariotti, Vânia G. Furlani, Willian Grassi Bautz, pelo excelente convívio, ajuda e suporte não somente nesta pesquisa. Muitíssimo Obrigado!

Aos demais colegas do Departamento de Anatomia do Instituto de Ciências Biomédicas da Universidade de São Paulo, Alexandre de Melo, Cristiane Cabral Costa, Eduardo Henrique Beber, Fátima de Souza e Freitas, Gisele Reisdoerfer, Guilherme Cotomacci, Leila Guissoni, Luciane Portas Capelo, Luciano Gonçalves, Márcia Sanae Mizuno, Maria Teresa Jordão, Pedro Omori Ribeiro de Mendonça, Priscila Girotti, Renata de Vasconcelos, Ricardo Bandeira, Rúbia Misawa, Tatiana de Lourdes Fonseca, Thompson Eusébio Pavan Torres, Wilma Allemandi, pela cooperação indispensável na realização deste trabalho

As Secretarias do Departamento de Anatomia, Cristiane Vitor Pinheiro, Maria Cristina dos Santos Faustino e Patrícia Rodrigues de Campos Rocha, pela prontidão e auxílio quando necessário.

Aos Técnicos e Funcionários do Departamento de Anatomia, Carlos Roberto Caldas, Edson Dantas da Silva, Everton Luís Pavan Torres, Iracema Caldas, José Adão Mendes, Milton Pereira da Silva, Sebastião Aparecido Boleta, Sônia Regina Yokomizo de Almeida, em especial a "professora" Marta Maria da Silva Righetti pelo carinho maternal com o qual conduziu seus ensinamentos.

A "professora" Rosana Duarte Prisco, pelo conhecimento transmitido e empenho mérito neste trabalho.

Aos funcionários do Biotério do Departamento de Anatomia do Instituto de Ciências Biomédicas da Universidade de São Paulo, Alessandro Rodrigo Martins, Fábio França Luiz e Renivaldo de Souza, por todo apoio prestado.

A Gerente de Projetos do Departamento de Anatomia do Instituto de Ciências Biomédicas da Universidade de São Paulo, Maria Cristina Ribeiro Freire, pela colaboração quando solicitada. 
À Maria Lúcia de Campos Motta, do setor de Comunicação Visual do Departamento de Anatomia do Instituto de Ciências Biomédicas da Universidade de São Paulo.

Aos profissionais do Centro de Informática do Instituto de Ciências Biomédicas da Universidade de São Paulo, em especial à Marilene Guimarães, pela assistência prestada.

Aos Funcionários, Celso Dias Pereira e Luciana Vicente da Silva, Seção de Pós-Graduação do Instituto de Ciências Biomédicas da Universidade de São Paulo.

Aos Funcionários da Biblioteca do Instituto de Ciências Biomédicas da Universidade de São Paulo, em especial aos profissionais do setor COMMUT, pela assistência exemplar.

Ao Conselho Nacional de Desenvolvimento Científico e Tecnológico por prover a bolsa de mestrado.

E meus cordiais agradecimentos, às pessoas que de uma maneira ou de outra contribuíram para a realização desta dissertação, e que os nomes estão aqui omitidos. 
“Eu estava faminto e você instalou um comitê para investigar a minha fome;

Eu estava sem casa e você preencheu um formulário com a minha reclamação;

Eu estava doente e vocêfez um seminário sobre a nutrição dos pobres;

Você investigou todos os aspectos do meu lamento e, ainda assim, eu continuo com fome, sem casa e doente" 


\section{RESUMO}

BAPTISTA, J. S. Repercussões morfológicas no timo de ratos jovens submetidos à desnutrição protéica e à renutrição precocemente corrigida. 2008. 107 f. Dissertação (Mestrado em Ciências Morfofuncionais) - Instituto de Ciências Biomédicas, Universidade de São Paulo, São Paulo, 2008.

A desnutrição é uma doença multifatorial extremamente prevalente em países subdesenvolvidos afetando principalmente a população infantil. Desta forma, é importante se documentar os efeitos desta no sistema linfóide, principalmente no timo, por estar envolvido diretamente com a imunidade do organismo. Com análise por meio de monitoramento adequado, verificou-se o metabolismo dos grupos experimentais, além das repercussões morfológicas no timo de forma qualitativa e quantitativa. Utilizaram-se 30 ratos wistar $(\hat{0})$ oriundos de ninhadas diferentes (heterogênios), distribuidos nos grupos Nutrido $(n=10)$, Desnutrido $(n=10)$ e Renutrido $(n=10)$, no qual 5 animais de cada grupo eram mantidos em gaiolas metabólicas (M) e 5 em caixas plásticas $(\mathrm{Cx})$ até completarem 60 dias. Os timos dos animais $\mathrm{Cx}$ foram submetidos às técnicas rotineiras em histologia (H.E., Weigert com Van Gieson, Tricromo de Masson e Picro-sírius, $\mathrm{n}=15)$. Os timos dos animais $\mathrm{M}$ seguiram à microscopia eletrônica de varredura (MEV, $\mathrm{n}=9$ ) e análise macromesoscópica $(n=6)$. A morfometria foi realizada em 5 cortes por animal. Contou-se 5 áreas por corte e 5 cortes por animal para estereologia. $O$ peso corporal final e a ingestão final de alimento foi maior nos animais $\mathrm{N}$, menor nos animais $\mathrm{D}$, enquanto os animais $R$ apresentaram valores médios entre estes grupos. Todos os outros parâmetros (ingestão de água, excreção de fezes, excreção de urina, \%ingestão/peso corporal, \%fezes/ingestão, água/peso corporal, \%urina/água consumida e peso tímico) não obtiveram diferença estatística entre o animal $\mathrm{N}$ e R, embora o peso tímico/peso corporal tenha sido maior para o animal R. Os animais $D$ exibiram cápsula tímica e septo interlobular delgado, com predominancia de fibras colágenas do tipo I. Severa atrofia dos lóbulos tímicos (menor número e tamanho), com limite córtex-medular muitas vezes indefinido, foi verificado para os animais $D$, além de vasos interlobulares e centrolobulares de menor calibre. A atrofia tímica dos animais $\mathrm{D}$ foi confirmada pela presença maior de timócitos em apoptose no córtex e medula tímica, garantindo também a menor \%Córtex tímico. A \%Medula tímica foi igual para os animais $\mathrm{R}$ e $\mathrm{D}$, tendo como escólio deste dado a menor \%Tecido não linfóide para os animais $R$. Poucos corpúsculos tímicos foram verificados no grupo $D$, destacando-se os tipos imaturo e maduro para animais $R$ e $D$, além de corpúsculos dilatados (envelhecidos). Somados a isso, estes animais apresentaram muitos vacúolos interlobulares sugestivos de tecido adiposo, comparativamente aos animais $\mathrm{N}$ que apresentavam poucos destes. Deste modo, afirma-se que os animais $\mathrm{R}$ conseguiram restituir a morfologia da glândula após intervenção nutricional, acreditando que as parecenças entre estes animais e os animais $D$ não interfiram no papel do órgão, espelhando o retorno funcional de suas atividades.

Palavras-chave: Timo, desnutrição, renutrição, análise morfoquantitativa, ultraestrutura. 


\begin{abstract}
BAPSTISTA, J.S. Morphologic repercussions in young rat thymus submitted to protein undernourishment and early corrected re-nourishment. 2008. $107 \mathrm{f}$. Master thesis (Morphofunctional Sciences) - Instituto de Ciências Biomédicas, Universidade de São Paulo, São Paulo, 2008.

Malnutrition is a multifactorial disease with high prevalence in developing countries, mainly affecting the child population. Thus, it is important to document the effects on the lymphoid system, for being involved directly with body's immunity, particularly in the thymus, for play an important role. Qualitative and quantitative morphologic repercussions were seeing, although the metabolism rate of experimental groups. 30 wistar rats $(\hat{O})$ were used from different broods (heterogenics), distributed in groups Nourished ( $N, n=10)$, Undernourished (UN, $n=10)$, Re-nourished ( $R N, n=10)$, whose 5 animals of each group were maintained in metabolic cages (M) and 5 animals in plastic box $(\mathrm{Pb})$. The thymus of animals maintened in $\mathrm{Pb}$ were submited to routine histology technniques (H.E., Weigert with Van Gieson, Masson and Sirius Red, $n=15)$. $M$ animals provided the thymus for scanning electron microscopy (SEM, $n=9$ ) and macro-mesoscopic analysis $(n=6)$. Morphometrical analysis was detained by 5 cuts per animal. 5 areas by cut and 5 cuts per animal for stereology. The final body weight and food ingestion was higher in $\mathrm{N}$ and lower in UN animals. While the other parameters as water ingestion, faeces excretion, urine excrecion, \%ingestion/corporal weigh, \%faeces/ingestion, water/corporal weight, \%urine/water consumed and thymic weight had no statistics differences between $\mathrm{N}$ and $\mathrm{RN}$ animals, although the thymic weight/corporal weight was superior in $\mathrm{RN}$ animals for presenting smaller body weight. The UN animals exhibited thin thymic capsule, and interlobular septum with predominance of type I collagen fibers, smaller caliber of inter and intra lobular vessels, atrophied thymic lobule (lower in number and size), without respecting cortex-medullar limit, unlike the $\mathrm{N}$ and $\mathrm{RN}$ animals that were showed similar morphology. The thymic atrophy was confirmed by the larger presence of thymocits apoptoses in the thymic cortex and medulla with smaller \%thymic cortex in the UN animals, while nodifferences between $\mathrm{N}$ and $\mathrm{RN}$ animals were seen. Few thymic corpuscles were verified in the UN group, accentuating the immature and mature types for RN and UN group; however extensive corpuscles (senescents) were presented. At the meantime, these animals had many interlobular vacuoles suggestive of fat compared to $\mathrm{N}$ animals. Therefore, the nutritional intervention restores the gland morphology in $\mathrm{RN}$ animals, and the resemblances between UN and RN did not indicate to interfere on the function activities of the organ.
\end{abstract}

Keywords: Thymus, undernourishment, re-nourishment, morphoquantitative analysis, ultrastructure. 


\section{LISTA DE FIGURAS}

Figura 1- Representação esquemática da formação dos grupos experimentais......40

Figura 2 - Monitoramento dos animais

Figura 3 - Técnica morfométrica utilizada através do sistema teste.

Figura 4 - Planimetria do corte transversal de timo

Figura 5 - Técnica estereológica aplicada através de sistema teste .49

Figura 6 - Comparação gráfica entre o peso corporal dos animais que tiveram monitoramento na caixa e na gaiola metabólica $(\mathrm{g})$.

Figura 7 - Gráfico da comparação entre o peso tímico dos animais que tiveram monitoramento na caixa e na gaiola metabólica $(\mathrm{g})$.

Figura 8 - Representação gráfica da porcentagem de peso tímico em relação ao peso corporal dos animais que tiveram monitoramento na caixa e na gaiola metabólica (\%). $\left(p<0,05^{\star}\right)$.

Figura 9 - Gráfico da média do peso corporal no final do experimento (g). $\left(p<0,05^{*}\right)$

Figura 10 - Gráfico representando a média de ingestão de ração por dia e por grupo (g). $\left(p<0,05^{\star}\right)$.

Figura 11 - Gráfico da média de ingestão de água por dia e por grupo (ml). $\mathrm{p}<0,05^{*}$.

Figura 12 - Representação gráfica da média de eliminação de urina por dia e por grupo $(g) . p<0,05^{*}$ 
Figura 13 - Gráfico da média de eliminação de fezes por dia e por grupo (g). $\mathrm{p}<0,05^{*}$.

Figura 14 - Gráfico temporal do ganho de peso corporal dos animais mantidos em gaiolas metabólicas.

Figura 15 - Gráfico temporal da ingestão de ração dos animais mantidos em gaiolas metabólicas.

Figura 16 - Gráfico temporal da ingestão de água dos animais mantidos em gaiolas metabólicas.

Figura 17 - Gráfico temporal da eliminação de fezes dos animais mantidos em gaiolas metabólicas.

Figura 18 - Gráfico temporal da eliminação de urina dos animais mantidos em gaiolas metabólicas.

Figura 19 - Gráfico da relação diária entre a ingestão de ração e peso corporal nos grupos experimentais $(\mathrm{ml} / \mathrm{g}) \cdot \mathrm{p}<0,05^{*}$.

Figura 20 - Gráfico da porcentagem diária de eliminação de fezes por ingestão de ração nos grupos experimentais (\%)

Figura 21 - Gráfica da relação diária entre ingestão de água e peso corporal nos grupos experimentais $(\mathrm{ml} / \mathrm{g}) . \mathrm{p}<0,05^{\star}$.

Figura 22 - Gráfico da relação diária entre a eliminação de urina e ingestão de água nos grupos experimentais $(\mathrm{ml} / \mathrm{g}) . \mathrm{p}<0,05^{*}$.

Figura 23 - Gráfico da média da relação entre massa corporal final e inicial no período experimental.

Figura 24 - Fotografia do timo de ratos de 60 dias 
Figura 25 - Fotografia da superfície do timo de ratos $N(A)$; D (B) e $R(C)$..... 66

Figura 26 - Fotomicrografia da cápsula tímica de ratos $\mathrm{N}(\mathrm{A})$; D (B) e R (C)..... .67

Figura 27 - Fotomicrografia da cápsula, septo interlobular e vasos interlobulares de timo de ratos dos grupos $N(A, D, G, J) ; D(B, E, H, L)$ e $R(C, F, I, M)$.

Figura 28 - Eletronmicrografias de varredura do timo de ratos dos grupos $\mathrm{N}(\mathrm{A}-\mathrm{B})$; D (C-D) e R (E-F). .70

Figura 29 - Fotomicrografia de timo de ratos. $N(A, D, G, J) ; D(B, E, H, L)$ e $R(C, F$, I, M).

Figura 30 - Fotografia e fotomicrografia de timo de ratos. N (A-B); D (C-D) e R (EF) 73

Figura 31 - Fotomicrografia do parênquima tímico de ratos $N(A-B)$; D (C-D) e R (EF)

Figura 32 - Fotomicrografia da MT de timo de ratos N (A-B); D (C-D) e R (E-F).....75

Figura 33 - Fotomicrografia da MT evidenciando-se corpúsculos tímicos nos animais $N(A, B)$; $D(C, D)$ e $R(E, F)$. .77

Figura 34 - Fotomicrografia de cortes histológicos do timo de ratos do grupo $D$ ( $A$,

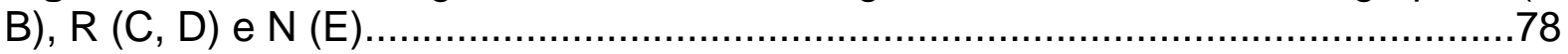

Figura 35 - Gráfico da porcentagem de córtex tímico na maior área de secção transversa $(\% \pm I C) . p<0,05 *$

Figura 36 - Gráfico representando a porcentagem de medula tímica na maior área de secção transversa $(\% \pm I C)$. $p<0,05 *$ 
Figura 37 - Gráfico da porcentagem de tecido não-linfóide na maior área de secção transversa $(\% \pm I C) . p<0,05 *$

Figura 38 - Gráfico da densidade de vasos na maior área de secção transversa (média $\pm \mathrm{DP}$ ). $\mathrm{p}<0,05 *$ 


\section{LISTA DE TABELAS}

Tabela 1 - Comparação quantitativa realizada entre os animais monitorados na caixa $(C x)$ e na gaiola metabólica $(M)$ durante o período experimental (Média \pm DP).

Tabela 2 - Média dos dados metabólicos do $1^{1^{0}}$ ao $39^{\underline{0}}$ dia de monitoramento $( \pm \mathrm{DP})$

Tabela 3 - Descrição das relações entre as médias diárias metabólicas $( \pm D P)$......61

Tabela 4 - Média $( \pm I C)$ da avaliação morfométrica da constituição dos lóbulos tímicos nos diferentes grupos de animais (N, D e R).

Tabela 5 - Estereologia da densidade de vasos centrolobulares na MT (média \pm DP)

Tabela 6 - Principais resultados experimentais 82 


\section{SUMÁRIO}

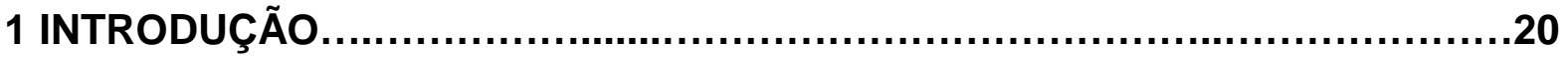

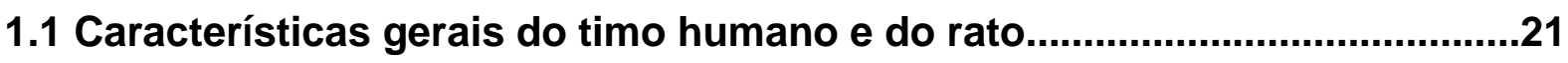

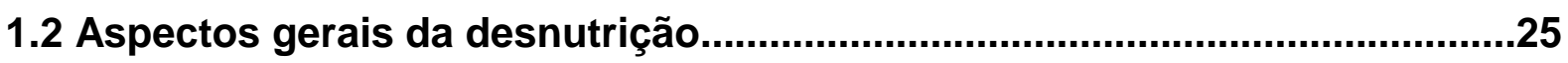

1.3 Repercussões morfológicas da desnutrição no timo.....................................28

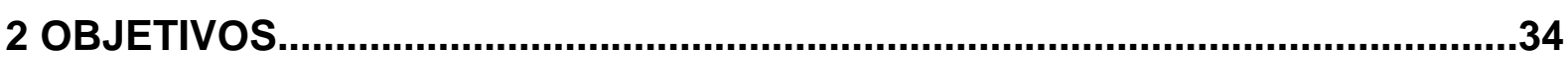

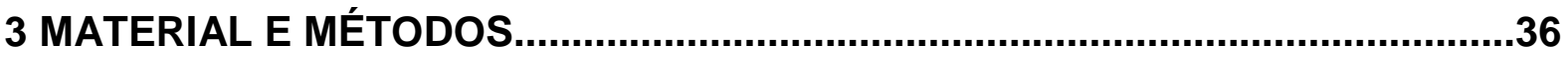

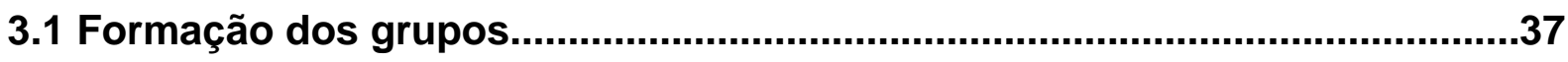

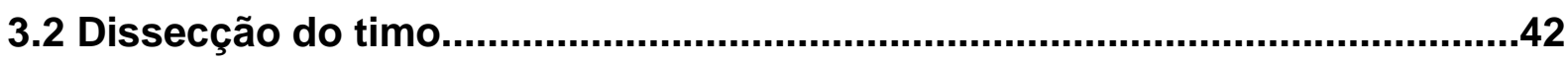

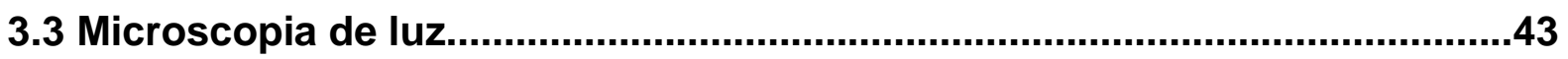

3.4 Microscopia eletrônica de varredura (MEV)................................................44

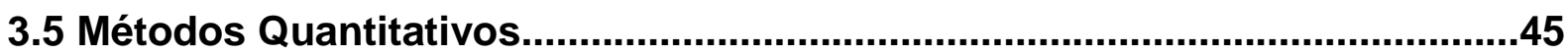

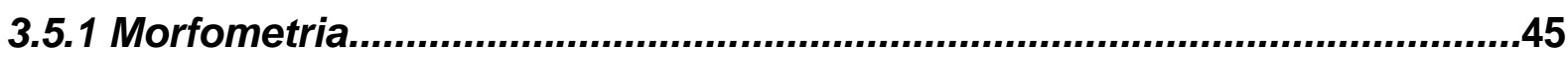

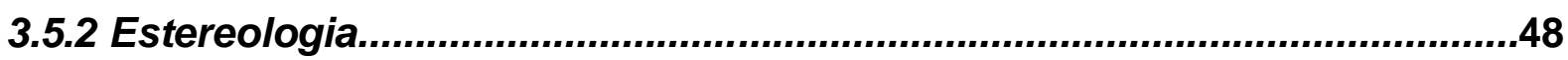

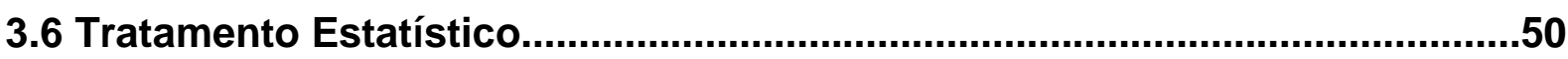

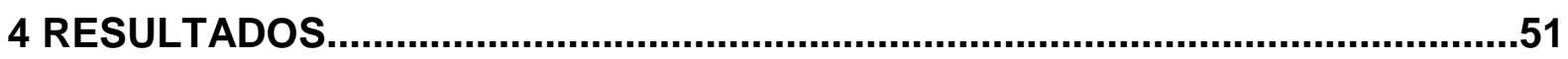

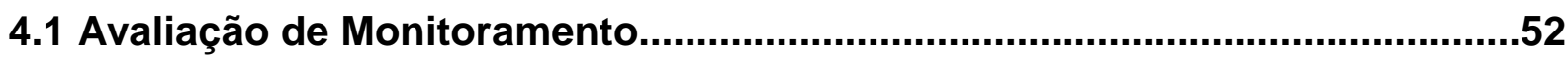

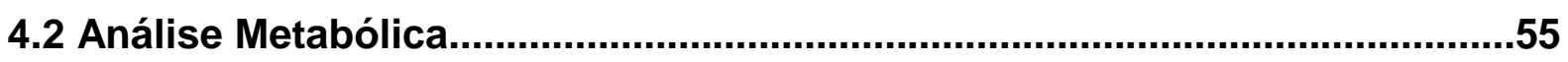

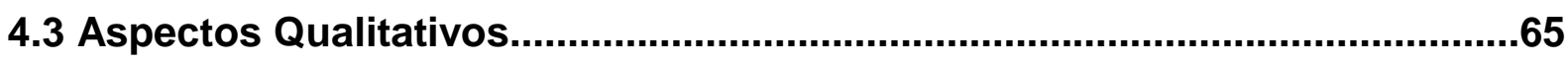

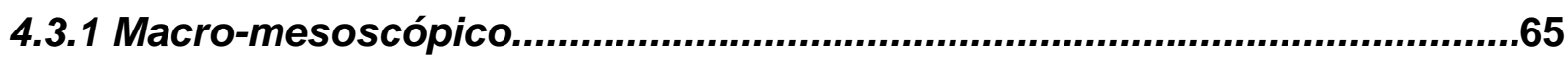

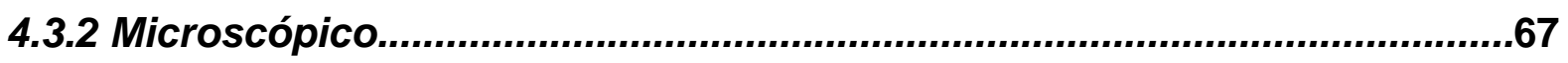

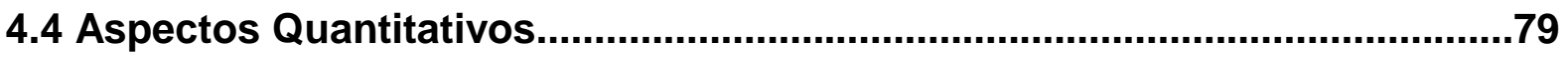

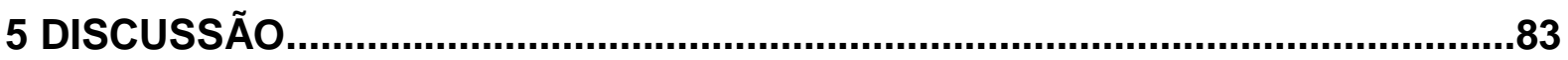

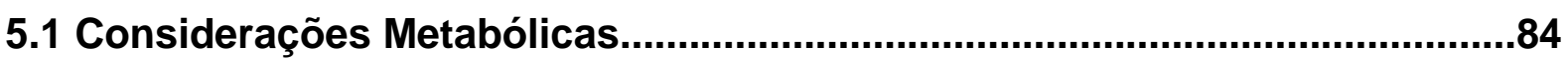

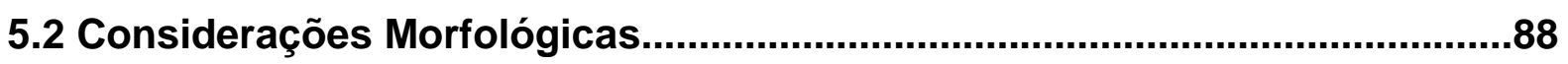

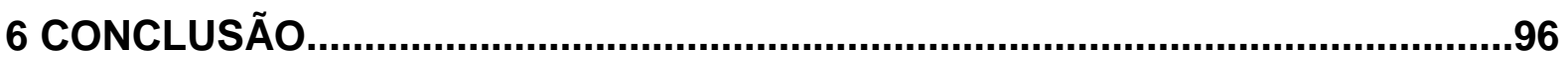

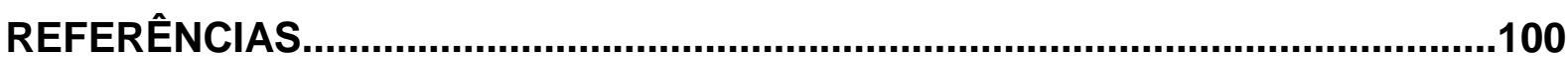


1 INTRODUÇÃO 


\subsection{Características gerais do timo humano e do rato}

O timo é um órgão linfoepitelial constituído de duas massas irregulares (variando de 1 a 3 ) denominadas lobos, situado na parte superior do mediastino anterior e à frente do pericárdio. Em crianças e em ratos jovens pode-se estender para a parte inferior do mediastino anterior, ou ultrapassar a abertura torácica superior chegando à parte inferior do pescoço (GARDNER; GRAY; O'RAHILLY, 1971; MOORE; DALLEY, 1994; PEARSE, 2006).

Assim como no homem os lobos tímicos do rato são envolvidos por tecido conjuntivo que invadem o parênquima dividindo-os em lóbulos menores, contínuos entre si que, em corte, apresentam uma camada periférica mais escura, ou região cortical e uma região central ou medular, mais clara, onde se encontram os corpúsculos tímicos ou de Hassall (HASSALL, 1846 ${ }^{\text {; }}$ apud BELL, 1906). Estas regiões são compostas pelas mesmas estruturas celulares (essencialmente timócitos), porém, em quantidades diferentes, sendo que a concentração maior destas é localizada na região cortical (JUNQUEIRA; CARNEIRO, 1999; LIBERTI et al., 1989; PEARSE, 2006).

O timo se diferencia de outros órgãos linfóides por duas razões: não possui nódulos e tem origem embriológica dupla, ou seja, seus linfócitos formam-se a partir de células mesenquimatosas que invadem um esboço epitelial originado da $3^{\mathrm{a}}$ e $4^{\mathrm{a}}$ bolsas faríngeas (SUSTER; ROSAI, 1990), enquanto os outros órgãos linfóides são de origem apenas mesodérmica. Segundo Van Ewijk et al. (1999) o timo é o único órgão linfóide porque, em contraste com os demais, é composto por células epiteliais.

\footnotetext{
${ }^{1}$ HASSALL, A.H. The microscopic anatomy of the human body in health and disease. London (1846).
} 
O parênquima do timo é formado por prolongamentos celulares de células reticulares unidas por desmossomos, formando uma malha onde os linfócitos se agregam e se diferenciam (SAVINO; SANTA-ROSA, 1982). Com isso as células mais abundantes do timo são as células reticulares epiteliais e os linfócitos $T$ ou timócitos.

As células reticulares epiteliais constituem uma rede com aspecto de esponja (malha ou parênquima) do córtex e da medula (VAN EWIJK, 1999), formam uma camada interna ao tecido conjuntivo da cápsula e dos septos, envolvem os vasos sanguíneos do parênquima (onde contribuem na formação da barreira hematotímica) e originam os corpúsculos tímicos. Nestes, as células reticulares epiteliais encontram-se achatadas e arranjadas concentricamente, unidas por numerosos desmossomos. Algumas dessas células situadas mais centralmente no corpúsculo se degeneram e morrem, dando origem a restos celulares que podem vir a se calcificar. Muito embora a estrutura dos corpúsculos tenha sido amplamente estudada (CARDELLINI; PANZICA; CANDIOLLO, 1980; LIBERTI, 1984), sua função ainda é assunto controverso (HALE, 2004; RAICA, 2006; SHEZEN et al., 1995).

Numa avaliação morfológica, Liberti (1984) descreve de forma perspicaz os dois tipos mais comuns conhecidos na literatura: sólido e cístico. Os corpúsculos sólidos são arranjados de forma circular, contínua e concentricamente, apresentando uma parte mais periférica e outra central, que lembram uma cebola cortada. Já os corpúsculos císticos não obedecem sempre uma forma circular, podendo ter material envolvido em seu interior, ou, até mesmo, estruturas calcificadas (alterações degenerativas), o que Ihe proporciona várias apresentações.

Raica et al. (2006) observa e avalia os corpúsculos em timos humanos oriundos de idades diferentes com auxílio de técnicas imunohistoquímicas, e sugere 
a classificação destes em 4 tipos: juvenil, imaturo, maduro e envelhecido, onde admiti-se a presença de todos os tipos em todas as idades. Os corpúsculos do tipo “juvenil" têm tamanho pequeno e comum, bem caracterizado pela forma ovóide e aspecto em casca de cebola. Os "imaturos" têm forma redonda ou oval, com acidofilia citoplasmática em seu interior, sem alterações degenerativas. Já os corpúsculos "maduros" se apresentam com tamanho médio e grande, com sinais de degeneração em sua porção central e, por fim, os corpúsculos "envelhecidos" que contêm material calcificado localizado centralmente, além de uma dilatação cística que lhe proporciona a maior estrutura dentre os corpúsculos.

Os linfócitos se multiplicam intensamente na região cortical dos lóbulos tímicos. Muitos sofrem apoptose e são captados e fagocitados por macrófagos, que também são encontrados em grande concentração nesta região. Em contrapartida ao número elevado de linfócitos da região cortical, somente uma pequena quantidade dessas células migram para a região medular onde penetram na corrente sanguínea e são transportadas para outros órgãos linfáticos (SAVINO; DARDENNE, 2000). Em seu estudo em humanos, Drenckhahn et al. (1978, 1979) observaram a existência de actina e miosina nas células reticulares epiteliais, e cogitaram a possível função destas células auxiliarem no movimento e na migração dos linfócitos dentro do timo.

A atividade mitótica do timo é muito alta e se processa quase que exclusivamente na região cortical. Devido a isso, a barreira hematotímica é encontrada somente nesta região, evitando que antígenos influenciem na formação e diferenciação dos linfócitos (WEISS, 1962). Acredita-se que, com esta grande atividade mitótica, o timo elimine mais de $90 \%$ dos linfócitos produzidos, uma vez que estes poderiam agir contra o próprio organismo (GUYTON; HALL, 2002). 
Além destas características, há aproximadamente cinco décadas têm sido descrita a atividade secretora das células reticulares epiteliais por possuírem vacúolos citoplasmáticos (MITTAL; WOODWARD, 1985), atribuindo a elas a ativação do sistema imune. Goldstein, Slater e White (1966) isolaram a timosina e descreveram que a secreção desta induz a proliferação linfocitária no timo e nos órgãos timo dependentes. Já Trainin et al. (1975) isolou o fator tímico humoral, e alguns anos depois demonstrou que este estava envolvido na diferenciação in vitro e in vivo de linfócitos T (TRAININ et al., 1979). Na pesquisa feita por Bach et al. (1975) o fator tímico sérico foi observado, e responsabilizado por ativação de subpopulações de células T. Com relação a timulina ou timopoetina, Goldstein (1975) descobriu seu comprometimento no bloqueio da transmissão da atividade neuromuscular, além de estar envolvida na indução da diferenciação linfocitária.

Relativamente ao peso corporal o timo atinge seu peso máximo no feto a termo e no recém-nascido, onde, após o primeiro ano de vida, não é registrado aumento de sua massa (STEINMANN, KLAUS, MÜLLER-HERMELINK, 1985). Os mesmos pesquisadores afirmam ainda, através de método estereológico, que o órgão sofre um processo de involução contínua após o nascimento correspondendo à diminuição de suas atividades, sem alterar a qualidade de suas funções imunológicas. Esse processo tem início na região cortical com depleção (mas não desaparecimento) dos timócitos de tal forma que, mesmo na terceira idade, resquícios do parênquima tímico (como corpúsculos tímicos, células reticulares epiteliais e alguns linfócitos) são envoltos por grande quantidade de tecido conjuntivo (PRELOG, 2006). 
Alguns outros fatores como gravidez, estado de coma, infecção, algumas terapias e variadas substâncias, principalmente corticosteróides, induzem a involução tímica (PARK et al., 2002).

Posto isso, Savino et al. (1989) estudou ratos infectados com Tripanossoma Cruzi e descreveu uma atrofia tímica e um crescimento anormal do baço (esplenomegalia) decorrente da infecção. Além disso, observou que a matriz extracelular do timo destes animais continha uma rede compatível com expansão, e que esta ocorria antes da morte dos timócitos. A estes achados o autor atribui ao nível elevado de corticosteróides circulantes no animal.

Já em outro estudo com ratos, Leite de Moraes et al. (1991) demonstrou num modelo experimental que utilizou a doença de Chagas, a ocorrência de níveis altos de corticosteróides circulantes atribuindo a este a atrofia tímica encontrada nestes animais.

Em ratos jovens submetidos a baixas temperaturas por oito semanas, MouraCampos e Savino (1988) viram que ocorre bastante perda de peso do timo, severa perda de linfócitos na região cortical e, através de métodos morfométricos, a contagem da superfície absoluta caiu pela metade no grupo experimental comparado ao controle. 


\subsection{Aspectos gerais da desnutrição}

A desnutrição é um problema que acomete principalmente as populações de áreas subdesenvolvidas do mundo, mais especificamente crianças, sendo conceituado pela Organização Mundial de Saúde (WORLD HEALTH ORGANIZATION, 1962) como um quadro de carência protéico-calórica. Este abrange formas graves de doenças como o marasmo, onde a ingestão calórica é insuficiente para satisfazer as necessidades energéticas e para que o organismo possa fazer seus próprios depósitos; e a Kwashiorkor, que é determinado por privação protéica severa (MONTE, 2000).

O marasmo é um produto final da adaptação metabólica à extrema carência energética. A criança marasmática apresenta um enfraquecimento muscular global, devido a uma perda severa da massa muscular e enrugamento da pele (CHANDRA, 1991; WATERLOW, 1997).

O Kwashiorkor é um dialeto do Gana, África, e significa: "aquele que foi colocado de lado". Refere-se ao filho que desmamou após o nascimento do irmão, tendo em vista que as crianças desta região se amamentam enquanto podem por causa da escassez de comida. Assim, esta patologia pode ser compreendida como uma incapacidade da adaptação à deficiência protéica, determinando em crianças entre outras alterações, um baixo peso para a idade, edema, despigmentação e ulceração da pele, além de perda de cabelos, que são características desta condição (MUGERWA, 1971; WATERLOW, 1997).

A desnutrição infantil ainda é um dos problemas mais importantes de saúde pública do mundo atual devido a sua magnitude e conseqüências desastrosas para o crescimento, desenvolvimento, e sobrevivência das crianças (MONTE, 2000). Isso 
as tornam mais suscetíveis a deficiência do sistema imunológico, infecções e atraso do desenvolvimento neuropsicomotor (NUNES, 2002). O crescimento em particular constitui um dos principais focos de atenção na saúde da criança sendo, o retardo antropométrico, o principal dado epidemiológico de desnutrição no Brasil e no mundo (ROMANI; LIRA, 2004; WATERLOW, 1997).

Em uma pesquisa que revisou 28 estudos epidemiológicos, 56\% das crianças desnutridas iam a óbito por infecções respiratórias agudas e/ou outras infecções (PELLETIER, 1995).

Um estudo realizado em 79 hospitais distribuídos em diversas partes do mundo revelou que 20 a $30 \%$ das crianças gravemente desnutridas, faleceram durante o tratamento nos serviços de saúde de países em desenvolvimento. Esta pesquisa também demonstrou que muitos profissionais da área da saúde não estão preparados, e/ou desatualizados quanto à conduta adequada para a reabilitação desta condição. (SCHOFIELD; ASWORTH, 1996).

Usando o banco de dados global de crescimento infantil da Organização Mundial da Saúde (WHO), Onis et al. (1993) investigou a desnutrição em 87\% total das crianças menores de 5 anos, baseado na nacionalidade entre 1980 e 1992 . Seus resultados afirmaram que mais de um terço desta população estudada é afetada com a desnutrição energético-protéica, concentrando $80 \%$ destes na Ásia, $15 \%$ na África e $5 \%$ na América Latina com quadro de baixo peso para a idade, fraqueza e atrofia muscular.

No Brasil as crianças desnutridas representam $15,4 \%$ do total da população infantil, ou seja, aproximadamente 2,5 milhões de indivíduos. A distribuição destas crianças no território brasileiro é desigual, relacionando-se com a pobreza e o retardo do crescimento. Com isso encontra-se na região Norte e Nordeste cerca de 
23 a $27,3 \%$ de crianças desnutridas, em contraste com as regiões do Centro-Sul onde esse número diminui para 8\% a 9\% (MONTEIRO, 1995).

\subsection{Repercussões morfológicas da desnutrição no timo}

A desnutrição durante o crescimento e desenvolvimento interfere na maturação de todos os órgãos e tecidos, mas no timo e em outros órgãos linfóides, estes danos são mais rapidamente evidenciados (SLOBODIANIK et al., 1989), tanto que Simon $(1845)^{2}$ apud Prentice (1999) o considerou como "barômetro da desnutrição".

Sendo o timo um órgão linfóide primário e responsável em grande parte pela imunidade, é importante se documentar estas mudanças ocorridas na desnutrição (BARONE; O`BRIEN; STEVENSON, 1993).

Após realizar uma avaliação epidemiológica em três vilas dependentes de sua agricultura no estado do Gâmbia, oeste da África, Moore et al. (1997) verificaram que os indivíduos que nasciam na chamada época de fome tinham 10 vezes mais chances de morrer no início da juventude por doenças infecciosas, do que os que nasciam na época de colheita. Segundo os autores isso demonstra que o prognóstico dos danos sofridos pelos tecidos linfóides no início da vida, é crítico, e que a época de nascimento dos indivíduos predizia a causa morte.

\footnotetext{
${ }^{2}$ SIMON, J. A Physiological Essay on the Thymus Gland. London: R Renshaw (1845).
} 
A perda de peso do órgão, a depleção de linfócitos e a conseqüente atrofia, são as principais conseqüências de qualquer tipo de desnutrição no timo humano ou animal (MITTAL; WOODWARD; CHANDRA, 1988).

Já foi demonstrado que a atrofia do timo decorrente da desnutrição se inicia pela diminuição de linfócitos corticais maduros. Esta diminuição é decorrente da morte celular (apoptose) particularmente no córtex tímico, podendo se estender a linfócitos imaturos no caso de uma condição crônica da desnutrição (DOUROV, 1986).

Mugerwa (1971) relatou a morfologia do timo de crianças com Kwashiorkor, onde não evidenciou o limite entre as regiões cortical e medular, além de grande atrofia de linfócitos com redução considerável (ou até mesmo a ausência) no número de corpúsculos tímicos. Descreveu ainda a dificuldade em se identificar o timo dessas crianças, devido à grande quantidade de tecido fibroso encontrado na região.

Diversas pesquisas têm descrito as alterações morfológicas do timo utilizando diferentes protocolos experimentais. Desta forma, Weindruch e Suffin (1980) demonstraram em ratos submetidos a uma alimentação calórica baixa e protéica alta por 3 semanas, que o peso do timo diminuiu sete vezes comparado ao grupo controle. Detectaram ainda, uma diminuição da relação peso corporal/peso tímico.

Lyra et al. (1993) analisaram o aspecto histológico, ultra-estrutural e imunohistoquímico de timos obtidos de necropsia de crianças mal nutridas, verificaram aumento de deposição de laminina, fibronectina e colágeno tipo IV e VI na matriz extracelular.

Já, Mittal e Woodward (1985) avaliaram o timo de ratos machos e fêmeas de 21 dias, mantidos sob restrição alimentar na ordem de 50\% por 14 dias (desnutrição energético-protéica). Notaram uma diminuição do peso corporal em 30\% comparado 
com os animais do grupo controle, e que o fator sexo não apresentou diferenças significativas. Observaram também que os animais com restrição tiveram acúmulo de colesterol, além de apresentar diminuição do tamanho do timo, depleção de timócitos e ausência de vacúolos citoplasmáticos das células reticulares epiteliais, indicando anormalidade da secreção hormonal exibida por estas células.

Em pesquisa onde utilizaram um grupo de ratos pós-desmame com restrição alimentar (50-60\%), e outro grupo submetido a uma dieta hipoprotéica $(0,3 \%$ de albumina) por 14 dias, Mittal, Woodward e Chandra (1988) observaram nos dois grupos uma diminuição do peso corporal (entre 20 e $30 \%$ ), e do peso do timo (de 83 a 96\%), além de uma considerável redução dos números de linfócitos particularmente na região cortical. A análise morfométrica não demonstrou alteração no volume de fração entre córtex e medula, mesmo nos animais desnutridos (mantendo-se de 2:1), apesar de ter havido um aumento do volume de fração do epitélio do córtex (reflexo da depleção dos timócitos), e não haver diferença no volume de fração do epitélio medular (reflexo de depleção do componente linfocitário e epitelial), muito embora tivesse sido menor nos dois grupos comparado com o controle.

Em estudos com ratos de 49 dias, Barone, O'Brien e Stevenson (1993) formaram 4 grupos de animais por um período experimental de 14 dias de acordo com a dieta: o primeiro (controle) foi mantido com 16\% de albumina, o segundo com 1\% de albumina, o terceiro com corticosteróide adicionado a ração industrializada e o quarto com ração industrializada, e injeção intraperitoneal de hidrocortisona (100 $\mathrm{mg} / \mathrm{kg}$ ) 48 horas antes da eutanásia. Observaram uma elevação (sete vezes maior) no nível de corticosteróide no segundo grupo quando comparado ao controle, responsabilizando este pela atrofia tímica expressiva encontrada nestes animais. Por 
outro lado, a produção de timócitos foi reduzida em todos os grupos experimentais. Notaram também que o grupo que recebeu corticosteróide não apresentou redução do peso corporal e, os animais que receberam injeção de hidrocortisona diminuíram em cinco vezes a produção de timócitos em apenas 48 horas, associado à depleção dessas células semelhante ao verificado para o segundo grupo.

No trabalho de Huang e Fraker (2003), a linfopoiese e hematopoiese foram estudadas em ratos de 35 dias submetidos a diferentes concentrações de proteínas na dieta por 15 semanas, através de três grupos experimentais: grupo controle que consumiu $180 \mathrm{~g} / \mathrm{kg}$ de proteína, grupo experimental 1 que consumiu $50 \mathrm{~g} / \mathrm{kg}$ de proteína por 15 semanas, e grupo experimental $2 \mathrm{com} 25 \mathrm{~g} / \mathrm{kg}$ de proteína por 5 semanas. Observaram que em comparação com o grupo controle, o grupo experimental 1 não sofreu nenhuma alteração no que diz respeito ao peso do timo, na sua produção celular, queda nos níveis séricos de albumina, minerais ou de corticosteróides; que é um indicador de desnutrição protéica ou energético-protéica. Opondo-se a este resultado, o grupo experimental 2 obteve uma significante perda de peso e atrofia tímica, além da diminuição em 13\% do zinco sérico e aumento em 505\% de corticosteróides circulantes. Contudo, os níveis de albumina sérica e outros minerais não foram alterados. Por fim, estes autores concluíram que a restrição crônica de proteína não altera a hematopoiese na medula óssea, nem a linfopoiese no timo de ratos adultos jovens.

Aplicando vários testes de função para as células T, Lamont, Gordon e Fergunson (1988) avaliaram ratas após o desmame por 11-12 semanas com dietas de $4 \%$ e $24 \%$ de proteína. Um de seus resultados foi que o grupo de $4 \%$ tinha resposta imune imatura, sustentando a idéia que a privação protéica promove um atraso na maturação imunológica. Revelaram também que neste mesmo grupo de 
privação protéica, a avaliação das células T por si só, não mostrava danos irreversíveis, sugerindo que estas células ficam impedidas de agirem funcionalmente devido ao estado de desnutrição do animal.

Com relação ao nível sérico de timopoetina, McDade et al. (2001) publicou em seu estudo, que acompanhou crianças desde o nascimento até a adolescência, que os nascidos com tamanho adequado para a idade ou, que se amamentaram por mais tempo, tinham maior nível sérico deste hormônio circulante, o que é associado a função tímica normal. No entanto, Chandra (1989) e Jambon et al. (1988) relatam que ocorre uma diminuição do número de células produtoras de timulina em crianças que faleceram em decorrência da desnutrição.

Em outro estudo, cujo modelo experimental eram ratos de 21 dias deficientes em zinco, Dardenne et al. (1984) observaram nestes animais diminuição dos níveis circulantes de timulina, gerando a hipótese que este hormônio contém zinco em sua estrutura.

Revillard e Cozon (1990) descreveram que na desnutrição protéico-calórica ocorre dilatação e degeneração dos corpúsculos de Hassall ou corpúsculos tímicos, baixos níveis de timulina, e perda de linfócitos no timo e nas áreas timo-dependentes (placas de Peyer, linfonodos e baço).

Particularmente em relação à renutrição, Barone, O'Brien e Stevenson (1993) afirmaram que a atrofia tímica gerada pela desnutrição pode ser revertida se a alimentação balanceada for retomada, assim como Lesourd e Mazari (1997) concluíram em seu estudo que a renutrição é uma ferramenta importante no retorno das atividades normais do sistema imune; porém, nenhum destes autores referidos apresentou se quer qualquer resultado que pudessem comprovar esse fato. 
Contudo, a desnutrição principalmente no início da vida causa sérios danos na resposta inflamatória (LYRA et al., 1993; SAVINO et al., 2006, 2007), na resposta imune mediada por células (SELLMEYER et al., 1972), além de poder acelerar o desenvolvimento espontâneo de doenças auto-imunes (REVILLARD; COZON, 1990). Vários especialistas em nutrição humana concordam que é preciso mais pesquisas básicas nesta linha. Existe hoje a urgência de se diagnosticar com precisão a gravidade da desnutrição, para aplicar ferramentas confiáveis no processo de renutrição, e assim se reverter este quadro de maneira eficaz (PICHARD, 1997). 
2 OBJETIVOS 
Examinar, utilizando o monitoramento apropriado, os ratos nutridos, desnutridos e renutridos e, avaliar os respectivos timos sob a microscopia de luz e eletrônica de varredura, com o auxílio de técnicas de morfometria e de estereologia, os aspectos:

1. Metabólicos dos animais;

2. Dimensionais do órgão;

3. Qualitativos do parênquima tímico;

4. Quantitativos do parênquima. 
3 MATERIAL E MÉTODOS 


\subsection{Formação dos Grupos}

Foram utilizados Rattus norvegicus da linhagem Wistar, 15 machos e 15 fêmeas, com idades entre 90 e 120 dias, providos do Biotério Central do Instituto de Ciências Biomédicas da Universidade de São Paulo (ICB/USP), e mantidos no Biotério do Departamento de Anatomia deste mesmo instituto. A utilização desta espécie foi escolhida por ser a mais usada em pesquisas que estudam a nutrição, o metabolismo e o timo, além da facilidade de manipulação e suporte pré-existente no biotério no qual foram mantidos. Posto isso, estes animais acasalaram durante um período de 7 dias mantidos em gaiolas plásticas, em salas climatizadas, com temperatura controlada entre 23 e $25{ }^{\circ} \mathrm{C}$ de maneira artificial, e com ciclo claro/escuro de 12 horas. Neste período foi oferecida aos animais, sem restrições, água e uma ração: protéica ( $20 \%$ de caseína) para o grupo controle ou nutrido ( $\mathrm{N}$, $\mathrm{n}=5$ casais), ou hipoprotéica ( $5 \%$ de caseína) para o grupo experimental, ou desnutrido ( $D, n=10$ casais). As rações foram preparadas por um laboratório bioquímico especializado ${ }^{3}$ de acordo com o "American Institute of Nutrition" para padronização de dietas em animais de laboratório (REEVES; NIELSEN; FAHEYJÚNIOR, 1993).

Após o acasalamento e constatação de que as fêmeas estavam prenhas, estas foram separadas em gaiolas individuais seguindo as mesmas dietas do período de acasalamento: N (5 fêmeas) e D (10 fêmeas). Passados 12 dias após a constatação da prenhe, verificava-se as gaiolas diariamente, e no mesmo horário, para constatar o dia do nascimento dos animais (este período variava entre o $12^{\circ} \mathrm{e}$ $19^{\circ}$ dias).

\footnotetext{
${ }^{3}$ Rhoster indústria e comércio LTDA, Araçoiaba da Serra, S.P., Brasil.
} 
Para padronização do experimento foram utilizadas em ambos os grupos ninhadas com 6 filhotes, desprezando-se aquelas com número inferior, e os animais excedentes de ninhadas com número superior. A adoção desse critério permitiu a obtenção de animais com menor discrepância de massa corporal, sendo também uma tentativa de se evitar um elevado índice de mortalidade nas ninhadas do grupo D, fenômeno este que ocorre tanto por condições intrínsecas devido ao tipo de privação protéica, como pelo fato de algumas mães se alimentarem dos próprios filhotes (neste caso, as ninhadas também foram desprezadas). Ainda sim, este critério tem intuito de promover o mesmo estresse entre as mães dos respectivos grupos, permitindo desta maneira que a ração seja a única forma de diferença entre elas.

As mães foram mantidas com as respectivas dietas até que seus filhotes completassem 21 dias de vida extra-uterina, época determinada para o desmame. Dois machos de cada ninhada experimental foram escolhidos aleatoriamente, para padronização do experimento; os animais não eleitos foram excluídos do estudo, sendo então eutanasiados. Após esta etapa formaram-se os seguintes grupos:

- Controle (N) - ou nutridos, mantidos com a dieta protéica até 60 dias de idade $(n=10)$;

- Experimental I (D) - ou desnutridos, mantidos com a dieta hipoprotéica até 60 dias de idade $(n=10)$;

- Experimental II (R) - ou renutridos, formado por animais desnutridos que, a partir do $22^{0}$ dia, foram mantidos com a dieta protéica, até 60 dias de idade $(n=10)$. 
Após a formação dos grupos, procedeu-se a dois tipos de monitoramento:

1. Na caixa (Cx): Cinco animais de cada grupo $(N, D, R)$ foram mantidos em gaiolas retangulares, sendo um por gaiola, medindo aproximadamente $60 \times 35 \mathrm{~cm}$, com grade de proteção superior em alumínio, sob estante vertical, até completarem 60 dias.

2. Metabólico (M): Cinco animais de cada grupo (N, D, R) foram mantidos em gaiolas metabólicas ${ }^{4}$, sendo um animal por gaiola, sob estante vertical apropriada, onde foram mensurados diariamente e no mesmo horário, o peso corporal, a ingestão de água e ração, e a excreção dos animais; sempre com os mesmo instrumentos para se controlar ao máximo, as possíveis variações.

A figura 1 ilustra o protocolo experimental de maneira esquemática, e a figura 2 demonstra os tipos de monitoramentos utilizados na pesquisa.

\footnotetext{
${ }^{4}$ TECNIPLAST®, modelo 3700M081, Buguggiate, Va, Itália
} 


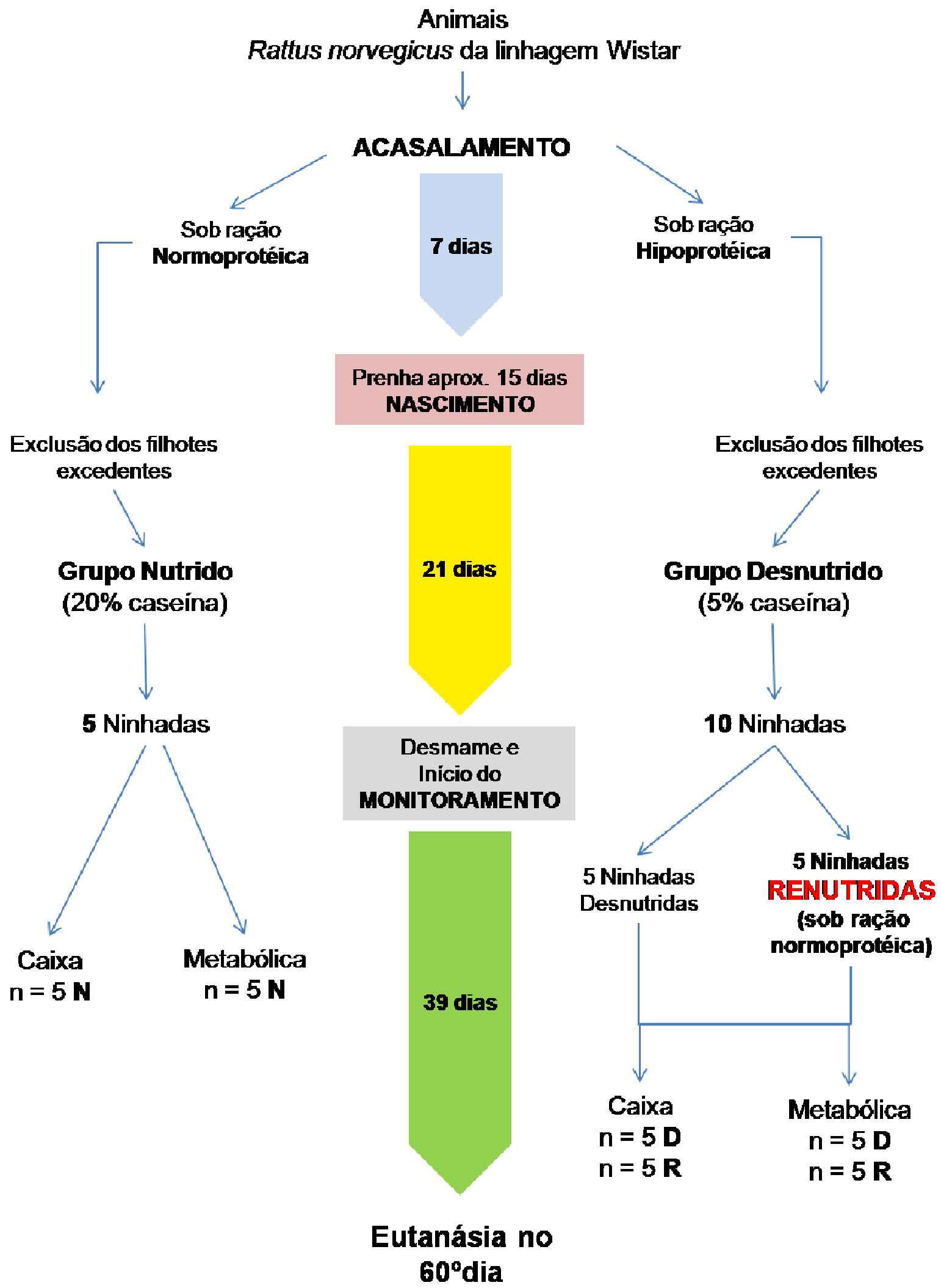

Figura 1 - Representação esquemática da formação dos grupos experimentais. 

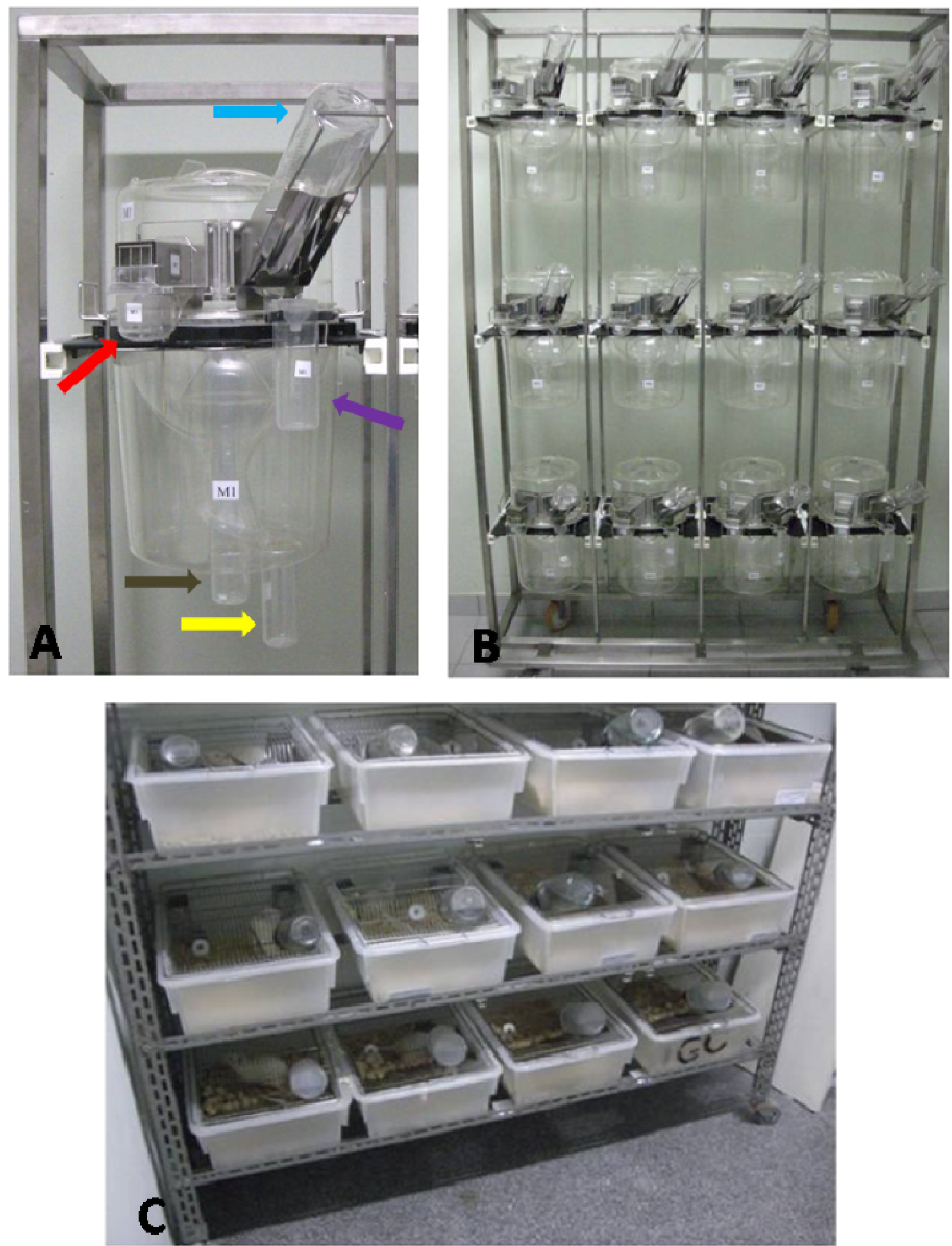

Figura 2 - Monitoramento dos animais. (A) Gaiola metabólica, (B) Estante vertical com 12 gaiolas metabólicas, (C) Caixas plásticas retangulares, e estante de acondicionamento tradicional. Garrafa de acondicionamento de água (seta azul), recipiente de armazenamento e verificação de desperdício de ração (seta vermelha), tubo coletor da água desperdiçada (seta roxa), tubo coletor de fezes (seta marrom), tubo coletor de urina (seta amarela). 
O período de 60 dias foi estabelecido por corresponder à fase púbere do rato (VIAU et al., 2005).

Ao final totalizou-se 10 animais de cada grupo $(5$ monitorados metabolicamente e 5 monitorados nas caixas de acordo com sua dieta), que foram submetidos à eutanásia através de câmara de dióxido de carbono ${ }^{5}\left(\mathrm{CO}_{2}\right)$, para a retirada do timo. O peso final do animal foi adquirido momentos antes da eutanásia.

\subsection{Dissecção do Timo}

O processo de retirada do timo teve início com uma incisão na pele do abdome em sua região mediana, próximo ao ângulo costal, aprofundando o corte e atravessando a estratigrafia de sua parede ântero-lateral, para expor o processo xifóide do osso esterno e ganhar a cavidade peritoneal. Esta incisão seguiu lateralmente na margem costal até a região lateral média do animal, bilateralmente, expondo suas vísceras e o músculo diafragma. A partir daí este último foi dissecado de suas inserções permitindo assim adentrar a cavidade pleural e já identificar os pulmões e o coração, além dos ligamentos esternopericárdicos. Então, se procedeu com uma incisão bilateral através das costelas em forma de "V" invertido, até alcançar à abertura torácica superior, dissecando suas estruturas anexas para que, em seguida, tracionando no sentido cranial o processo xifóide com o auxílio de uma pinça hemostática, o timo fosse exposto. De maneira cuidadosa, foram separadas as estruturas adjacentes ao órgão com o auxílio de material cirúrgico utilizado em oftalmologia (pinças e tesouras). Após a retirada, o timo dos animais de todos os grupos ( $N$, D e R) foram pesados e preparados para as técnicas de microscopia de luz e eletrônica de varredura.

\footnotetext{
${ }^{5}$ Biotério do Departamento de Anatomia do ICB/USP
} 


\subsection{Microscopia de luz}

Os timos foram acondicionados para fixação, em tubos apropriados com solução de formalina a $10 \%$, com quantidade 2 vezes o seu tamanho por no mínimo 72 horas. Dois exemplares de cada grupo (N, D, R), providos dos animais monitorados nas gaiolas metabólicas foram corados com azul de toluidina (BEHMER; TOLOSA; FREITAS-NETO, 1975), para melhor observação macromesoscópica.

Após esta etapa, os timos sujeitos a técnica de microscopia de luz seguiram à desidratação em série crescente de álcoois $\left(70^{\circ}\right.$ ao absoluto), diafanização em xilol e em seguida, inclusão em parafina ${ }^{6}$.

Cortes semi-seriados de $6 \mu \mathrm{m}$ de espessura, realizados na região correspondente à maior área de secção transversa do órgão, foram submetidos às técnicas de coloração da Hematoxilina-eosina (BEHMER; TOLOSA; FREITASNETO, 1975), para evidenciar o córtex e a medula, bem como dos corpúsculos tímicos; do Tricomo de Masson (ROMEIS, 1968), para análise das estruturas associadas aos lobos tímicos como cápsula e vasos; da resorcina-fucsina (WEIGERT, 1898) contra-corada pela técnica de Van Gieson (BEHMER; TOLOSA; FREITAS-NETO, 1975), para a detecção de fibras elásticas e do Picro-sirius (MONTES; JUNQUEIRA, 1991), para a diferenciação dos tipos de fibras colágenas sob luz polarizada ${ }^{7}$.

A montagem dos cortes foi realizada entre lâmina e lamínula, com Entellan ${ }^{8}$.

\footnotetext{
${ }^{6}$ Processamento histológico realizado no Laboratório Multiusuário de Histologia do Departamento de Anatomia do ICB/USP.

${ }^{7}$ Carl Zeiss Microimaging, modelo Axioshop 40, Göttingen, Alemanha. Laboratório de Anatomia Funcional Aplicada à Clínica e Cirurgia - LAFACC

${ }^{8}$ MERCK, Darmstadt, Alemanha
} 


\subsection{Microscopia Eletrônica de Varredura (MEV)}

Três timos de animais monitorados em gaiolas metabólicas, oriundos de cada grupo experimental $(\mathrm{N}, \mathrm{D}, \mathrm{R})$, foram utilizados para o estudo da morfologia ultraestrutural. Ao completarem 60 dias de vida pós-natal, os animais foram anestesiados com solução anestésica ${ }^{9}$ (combinado de cloridrato de tiletamina e cloridrato de zolazepam, na proporção de 0,8 ml/kg de peso corpóreo, i.m., dose anestésica), e perfundidos através do ventrículo esquerdo com solução de Karnowsky modificada ( $2 \%$ de parafolmaldeido, $25 \%$ de glutaraldeido e tampão fosfato, $\mathrm{pH} 7,3 ; 2$ Molar).

Os espécimes seguiram imersos na mesma solução fixadora por um período mínimo de 48 horas a $4{ }^{\complement} \mathrm{C}$ quando, então, foram lava dos em solução de tampão fosfato e colocados em recipiente metálico contendo nitrogênio líquido, sendo imediatamente congelado. Logo após, o procedimento de criofratura era realizado com instrumentos apropriados.

Em seguida, os fragmentos do órgão foram pós-fixados por imersão em uma solução aquosa de tetróxido de ósmio a 1\%, por 2 horas, seguido de desidratação em série crescente de alcoóis (de $70^{\circ}$ ao absoluto), onde permaneceram no álcool absoluto até serem submetidos ao ponto crítico ${ }^{10}$. Feita esta etapa, os fragmentos foram devidamente posicionados para observação em bases metálicas apropriadas, metalizados com ouro ${ }^{11}$ e analisados em um microscópio eletrônico de varredura ${ }^{12}$.

\subsection{Métodos Quantitativos}

\footnotetext{
${ }^{9}$ Zoletil ${ }^{\circledR} 50, \operatorname{Virbac} \AA$

${ }^{10}$ BAL-TEC, modelo CPD-030, Schalksmühle, Alemanha. Departamento de Anatomia ICB/USP.

${ }^{11}$ BALZERS, modelo SCD-040, Reinraumtechnik Lanz, Alemanha. Departamento de Anatomia ICB/USP.

${ }_{12}$ LEO, modelo 435 VP, Departamento de Anatomia dos Animais Domésticos e Silvestres da Faculdade de Medicina Veterinária e Zootecnia.
} 
As observações quantitativas das estruturas envolvidas no parênquima tímico seguiram os métodos morfométricos e estereológicos descritos por MANDARIM-DELACERDA (1995).

\subsubsection{Morfometria}

Para avaliar a porcentagem média equivalente a cada região do parênquima tímico, foram denominadas para quantificação as seguintes áreas: córtex tímico (CT), medula tímica (MT) e tecido não-linfóide (TNL), que por sua vez era constituído da cápsula tímica, septo interlobular, vasos interlobulares e centrolobulares (Figura 3).

Em lupa estereoscópica ${ }^{13}$ sob $0,8 x$ de aumento, acoplada a uma câmera digital $^{14}$, foi realizado o estudo de 5 cortes aleatórios por animal através de aparelho de aquisição de imagem computadorizada ${ }^{15}$, posicionando frente ao monitor do computador um sistema teste medindo $21 \times 16 \mathrm{~cm}$ contendo 300 pontos eqüidistantes a $1 \mathrm{~cm}$. Como neste sistema não se obtinha, numa só contagem, a porcentagem de área total das regiões, procedeu-se uma varredura de toda a extensão do corte histológico.

\footnotetext{
${ }^{13}$ Carl Zeiss Microimaging modelo Stemi SV6, Göttingen, Alemanha - LAFACC.

${ }_{15}^{14}$ Canon Inc. modelo Power Shot A640, China - LAFACC.

${ }^{15}$ Software axiovision Rel. 4.6, Göttingen, Alemanha - LAFACC.
} 


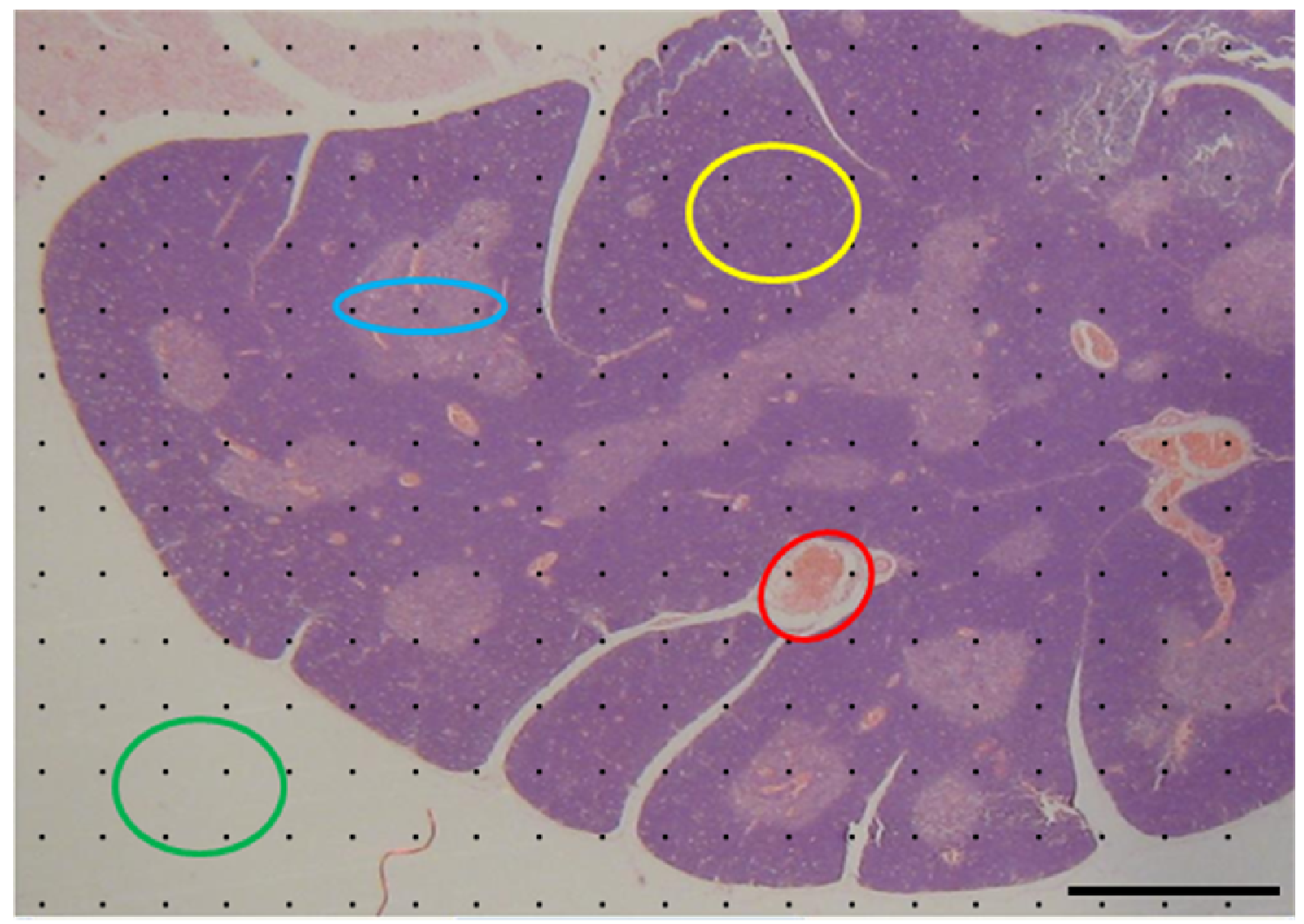

Figura 3 - Técnica morfométrica utilizada através do sistema teste. Pontos contados correspondentes a área do CT (círculo amarelo), pontos computados correspondentes a área da MT (círculo azul), pontos arranjados no septo e vaso interlobular e, portanto, correspondentes a área de TNL (círculo vermelho), área não contada (círculo verde). (H.E.: $1 \mathrm{~mm})$.

Como os dados fornecidos pelo sistema teste são expressos apenas como pontos sobre estruturas, realizou-se a planimetria do corte para se estabelecer a correlação entre os pontos analisados e a área do corte (Figura 4). 

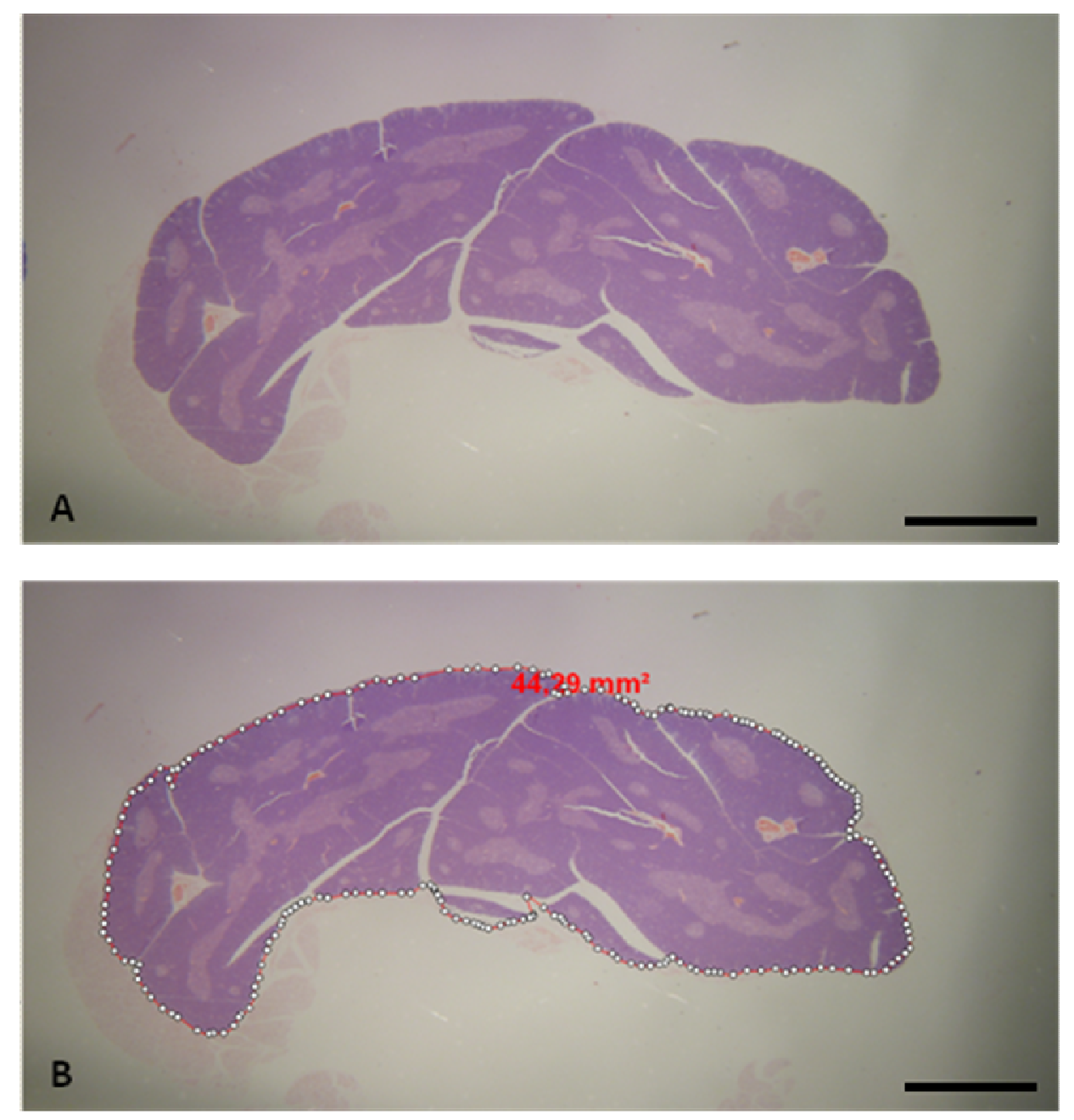

Figura 4 - Planimetria do corte transversal de timo. (A) Imagem do corte histológico. (B) Planimetria sobre a imagem, expressa em $\mathrm{mm}^{2}$. (H.E. A e B: $2 \mathrm{~cm}$ )

O intervalo de confiança (IC) dos dados morfométricos foi calculado pelo produto da curva de Gauss normal (z), pelo erro padrão da média (EP), (fórmula 1), representando a média \pm IC (FISHER; VAN BELLE, 1993). Admitiu-se que, com IC de $95 \%$ de confiabilidade, a curva normal de Gauss apresenta um valor $z=1,96$ (MANDARIM-DE-LACERDA, 1995).

$$
I C=E P \times Z \text { (1) }
$$




\subsubsection{Estereologia}

Para a elaboração do sistema teste estereológico foi calculada a densidade de volume do timo (2), através de um sistema com 300 pontos, onde foi determinado o número de pontos que caem sobre estrutura $\left(P_{P}\right)$ em relação ao número total de pontos $\left(\mathrm{P}_{\mathrm{T}}\right)$ contidos no sistema.

$$
\mathbf{V}_{\mathrm{V}}=\frac{\sum \mathbf{P}_{\mathbf{P}}}{\sum \mathbf{P}_{\mathbf{T}}}
$$

Isso permitiu o cálculo do erro padrão relativo (EPR, fórmula 3 sob a significância de 0,05 $=95 \%$ de confiabilidade estatística), estipulando Vv em 0,5 como índice de $50 \%$ dentro da estrutura e $50 \%$ fora da estrutura, no qual teve

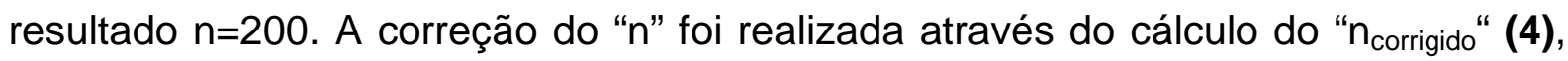
resultando no número de pontos contados sobre a amostra, que neste caso foram 400 pontos. Deste modo, contando apenas 400 pontos por animal, já se considerou como razoavelmente aceitável para os padrões estereológicos.

$$
\begin{aligned}
\text { EPR } & =\sqrt{\frac{\left(1-V_{v}\right)}{\mathbf{n}}} \\
\mathbf{n}_{\text {corrigido }} & =\frac{\mathbf{n}_{\text {calculado }}}{\mathrm{Vv}_{\mathbf{v}}}
\end{aligned}
$$

De forma a pesquisar a densidade de vasos do timo (densidade de perfis na área teste), a região medular foi escolhida por ser a área efluente de timócitos para o sistema circulatório (SAVINO; DARDENNE, 2000). Para tanto, foram adquiridas 5 
imagens com objetiva de 40x, de um mesmo corte e de forma aleatória, distribuídas em regiões medulares no sentido látero-lateral, que foram capturadas através do sistema de imagem computadorizada ${ }^{16}$. Este procedimento foi realizado em 5 cortes por animal, totalizando 25 imagens por animal ou, 125 imagens por grupo, reduzindo de forma eficaz o viés da amostra.

Um sistema teste tracejado medindo $21 \times 16 \mathrm{~cm}$, com 157 linhas (ou seja, dois pontos ligados entre eles no espaço), de $1 \mathrm{~cm}$ cada, arranjados de forma eqüidistante a $1 \mathrm{~cm}$, foi acoplado à frente do monitor do computador (Figura 5). A área do sistema teste no software correspondeu a $0,031 \mathrm{~mm}^{2}$.

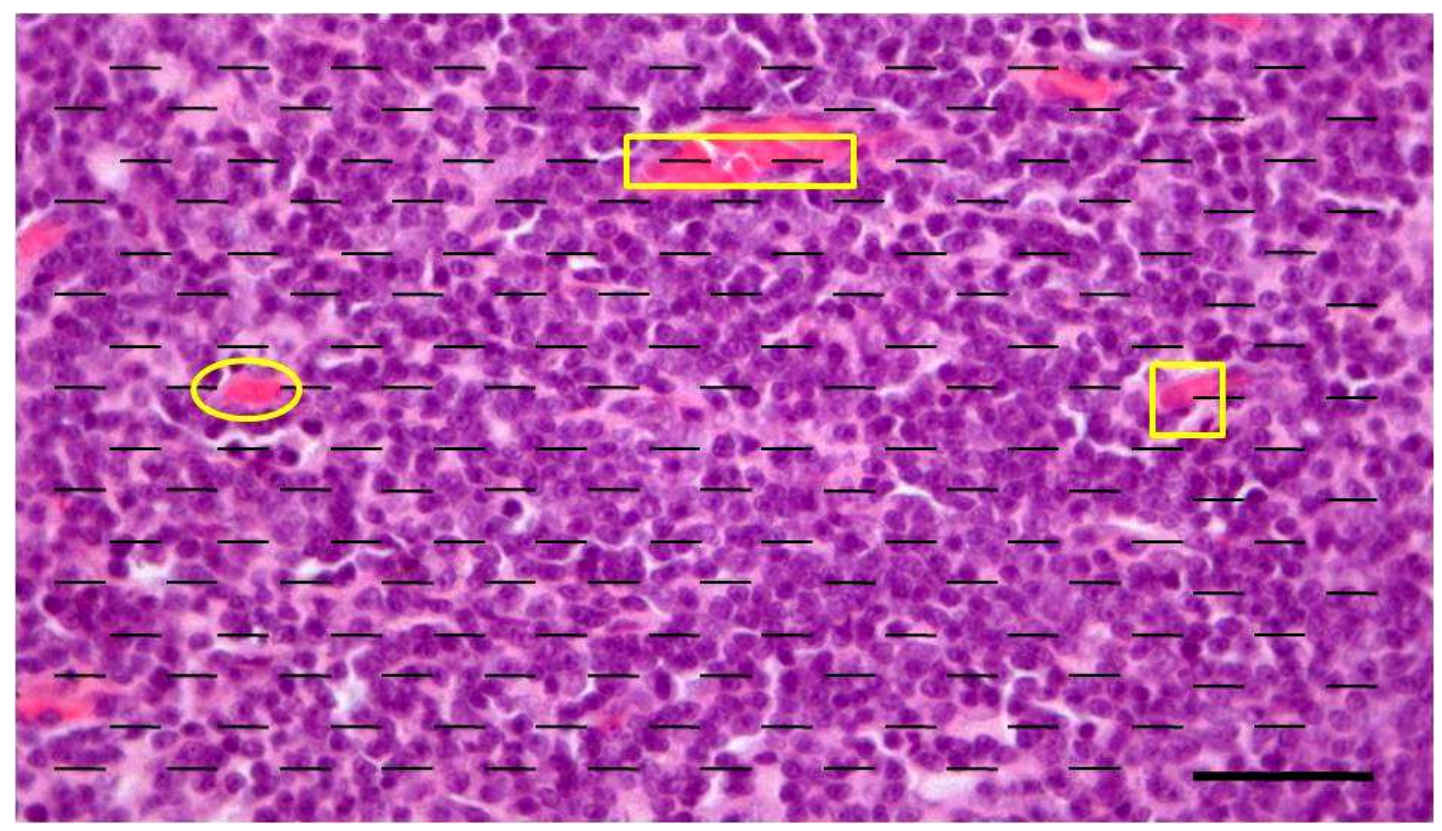

Figura 5 - Técnica estereológica aplicada através de sistema teste. Observar os vasos que se encontram no plano de corte em tom róseo escuro. Foi considerado como um ponto as linhas que tocam o vaso em apenas uma extremidade (quadrado). Contaram-se dois pontos no caso em que duas extremidades de dois traços diferentes tocavam o vaso (círculo), ou quando um traço inteiro estava posicionado em cima do vaso (retângulo contendo dois traços e, portanto, 4 pontos).(H.E.: $40 \mu \mathrm{m})$.

\footnotetext{
${ }^{16}$ Carl Zeiss Microimaging, modelo Axioshop 40 e câmera Axiocam ligados ao software Axiovision Rel. 4.6, Göttingen, Alemanha.
} 
Ao final, aplicou-se o coeficiente de erro dos parâmetros estereológicos (5) para afirmação da eficiência do método, prevendo uma análise sem viés com resultado aceitável menor que 10\%. (GUNDERSEN et al., 1988)

$$
C E=\frac{(E P) \times 100}{\text { média }}
$$

\subsection{Tratamento Estatístico}

Para confirmação dos resultados a seguir, foi aplicada a análise de variância (ANOVA) com dois fatores para as diferentes comparações, e a análise de variância com medidas repetidas para análise temporal, de acordo com as descrições de ZAR (1984). 
4 RESULTADOS 


\subsection{Avaliação de Monitoramento}

Com a utilização deste protocolo experimental e do monitoramento em gaiola metabólica foram constatadas algumas diferenças físicas e comportamentais nos animais dos grupos $N$, D e R. Surpreendentemente, as mães do grupo D pariram mais filhotes e estes por sua vez desenvolveram pêlos tardiamente comparados ao grupo N. Já no período onde os animais foram monitorados individualmente $\left(22^{0}\right.$ ao $60^{0}$ dia de vida ou do $1^{0}$ ao $39^{0}$ dia de monitoramento), os animais se apresentavam de maneira variável. Por vezes eram ativos e reativos tentando escapar da manipulação ou, ficavam hipoativos, letárgicos, sendo presente estas características em todos os grupos e inclusive no mesmo animal em períodos diferentes. Em várias ocasiões os animais do grupo D ficavam enclausurados no recipiente de comida da gaiola metabólica ou, no caso dos animais monitorados nas caixas, encobertos por maravalha. Ainda sim, estes animais apresentavam o pêlo uniformemente escasso, curto, e menos vistoso não sendo esta característica verificada para os animais $\mathrm{N}$ e R.

Alguns dos animais D, que foram monitorados nas gaiolas metabólicas, manifestavam uma sudorese intensa marcada pela transpiração vista na tampa superior desta. Já os animais $R$ manifestaram fezes pastosas no início da readaptação alimentar que, por muitas vezes, aderiram às paredes do coletor de fezes e não demonstravam o mesmo aspecto das fezes dos ratos $\mathrm{N}$ e D.

Com relação ao tamanho dos animais, o grupo $D$ era no mínimo duas vezes menor em comprimento que o visto para os outros grupos, muito embora os animais do grupo $\mathrm{R}$ tenham se mostrado ligeiramente menores que os do grupo $\mathrm{N}$. 
Ainda neste item foi realizada uma comparação estatística entre os dados obtidos dos animais de todos os grupos (N, D, R), mantidos em caixas normais, com aqueles verificados para os animais mantidos em gaiolas metabólicas. Desta forma, os parâmetros Peso corporal, Peso tímico e razão Peso tímico/Peso corporal foram estabelecidos, como um subsídio de análise sobre a possível intervenção desses dados na expressão da morfologia da glândula (Tabela 1).

Tabela 1 - Comparação quantitativa realizada entre os animais monitorados na caixa (Cx) e na gaiola metabólica $(\mathrm{M})$ durante o período experimental (Média \pm DP).

\begin{tabular}{lccc}
\hline Parâmetros & Nutrido & Desnutrido & Renutrido \\
\hline & & & \\
Peso corporal animais M (g) & $289,7 \pm 13,7$ & $58,6 \pm 18,6^{*}$ & $207,9 \pm 17,0^{*}$ \\
Peso corporal animais Cx (g) & $286,8 \pm 19,2$ & $61,6 \pm 12,5^{*}$ & $211,7 \pm 17^{*}$ \\
Peso tímico animais M (g) & $0,70 \pm 0,16$ & $0,15 \pm 0,06^{*}$ & $0,81 \pm 0,16$ \\
Peso tímico animais Cx (g) & $0,74 \pm 0,18$ & $0,16 \pm 0,04^{*}$ & $0,85 \pm 0,10$ \\
\%Peso tímico/corporal animais M & $0,24 \pm 0,04$ & $0,25 \pm 0,08^{*}$ & $0,39 \pm 0,07$ \\
\%Peso tímico/corporal animais Cx & $0,26 \pm 0,05$ & $0,26 \pm 0,06^{*}$ & $0,40 \pm 0,05$
\end{tabular}

A análise da tabela 1 permitiu verificar que, relativamente aos parâmetros Peso corporal e Peso tímico, muito embora tenha ocorrido um decréscimo na seguinte ordem: $\mathrm{N}-\mathrm{R}-\mathrm{D}$, ao se comparar esses valores dentro dos grupos entre os animais monitorados na $C x$ e $M$, não foram observadas diferenças estatisticamente significativas. (peso corporal $\mathrm{p}=0,830$; peso tímico $\mathrm{p}=0,506$ ). Quanto à razão Peso tímico/Peso corporal, expressa em porcentagem, o timo dos animais do grupo $\mathrm{R}$ representa a maior porcentagem entre os grupos; nos animais $\mathrm{N}$ e $\mathrm{D}$, essa relação 
se equivale. Quando se compara no mesmo grupo, os resultados do monitoramento entre Cx e M, não se verificam diferenças estatísticas significantes $(p=0,623)$.

Nos gráficos das figuras 6, 7 e 8, pode-se verificar as comparações relativas à tabela 1.

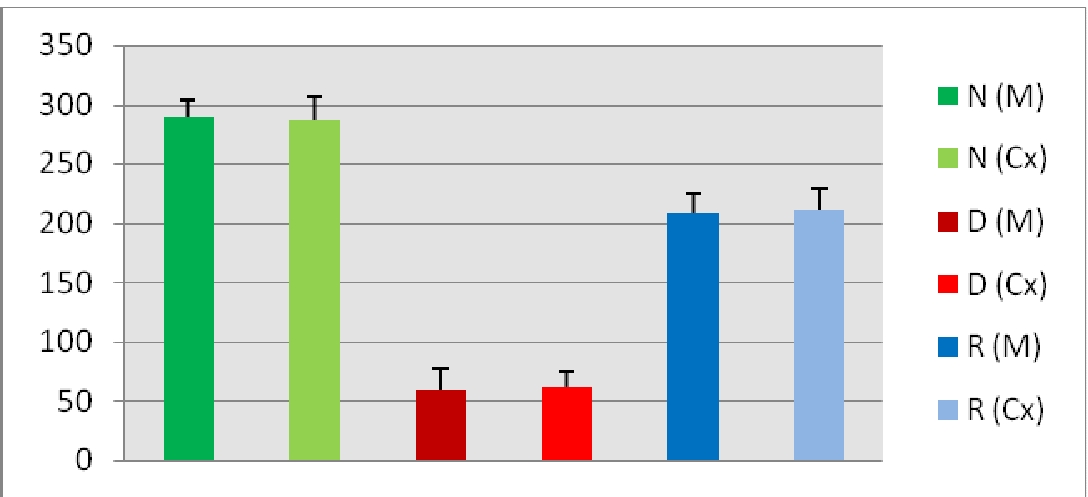

Figura 6 - Comparação gráfica entre o peso corporal dos animais que tiveram monitoramento na caixa e na gaiola metabólica $(\mathrm{g})$.

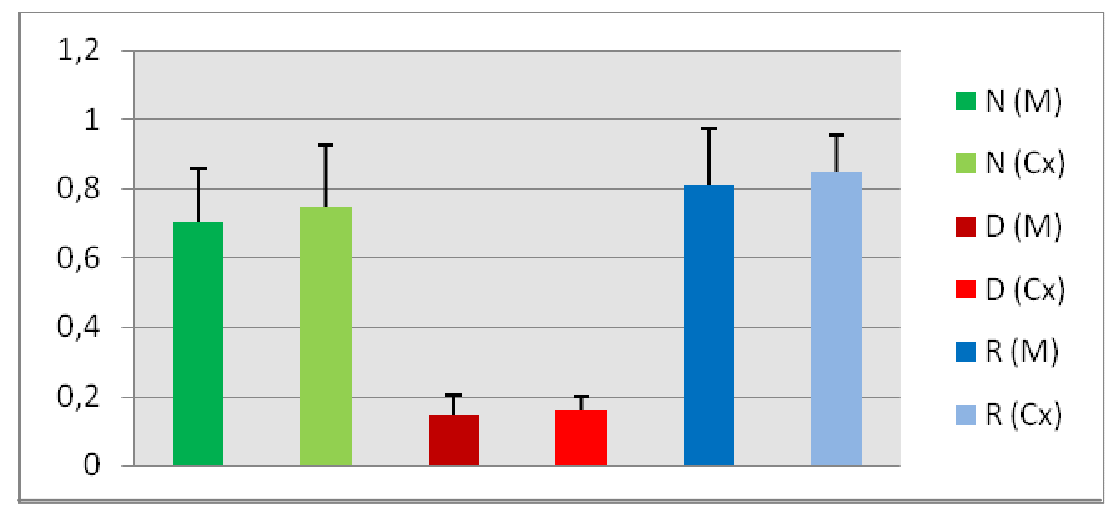

Figura 7 - Gráfico da comparação entre o peso tímico dos animais que tiveram monitoramento na caixa e na gaiola metabólica $(\mathrm{g})$.

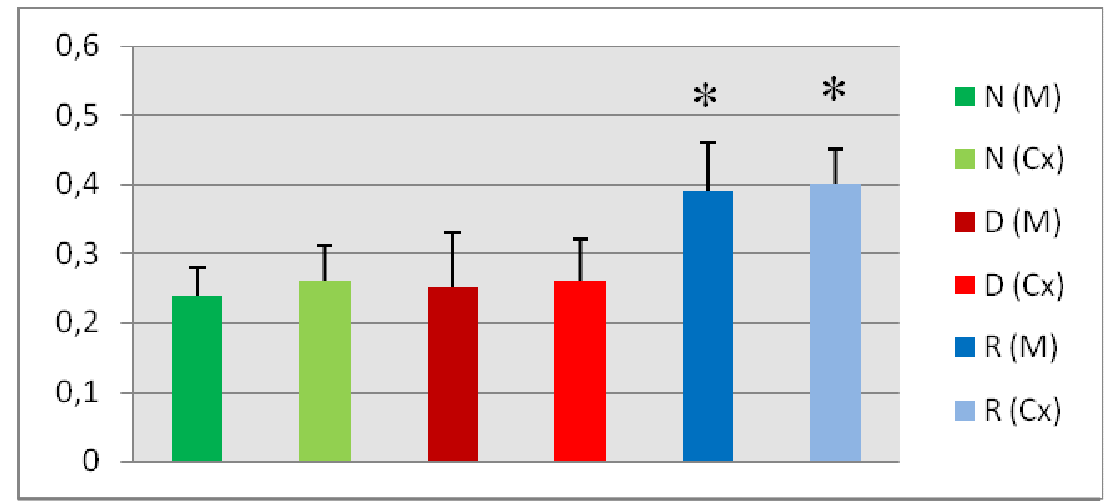

Figura 8 - Representação gráfica da porcentagem de peso tímico em relação ao peso corporal dos animais que tiveram monitoramento na caixa e na gaiola metabólica (\%), $p<0,05^{\star}$. 


\subsection{Análise Metabólica}

Para estabelecer relação entre o processo nutricional e o timo, como também os detalhes metabólicos que os animais manifestam decorrente desta intervenção, os dados sobre o peso corporal, ingestão de ração e de água, bem como da eliminação de urina e de fezes, foram adquiridos dos animais monitorados nas gaiolas metabólicas do $1^{0}$ ao $39^{0}$ dia de monitoramento, e estão expostos na tabela 2.

Tabela 2 - Média dos dados metabólicos do $1^{0}$ ao $39^{\circ}$ dia de monitoramento ( \pm DP).

\begin{tabular}{lccc}
\hline Parâmetros & Nutridos & Desnutridos & Renutrido \\
\hline Peso corporal $(\mathrm{g})$ & $289,7 \pm 13,7$ & $58,6 \pm 18,6^{*}$ & $207,9 \pm 17,0^{*}$ \\
Ingestão ração $(\mathrm{g})$ & $15,5 \pm 0,7$ & $7,5 \pm 1,0^{*}$ & $13,1 \pm 1,3^{*}$ \\
Ingestão de água $(\mathrm{ml})$ & $25,9 \pm 2,1$ & $11,4 \pm 2,4^{*}$ & $20,8 \pm 4,7$ \\
Eliminação urina $(\mathrm{ml})$ & $15,9 \pm 2,4$ & $5,9 \pm 1,6^{*}$ & $12,5 \pm 3,1$ \\
Eliminação fezes $(\mathrm{g})$ & $1,95 \pm 0,16$ & $0,98 \pm 0,26^{*}$ & $1,63 \pm 0,31$
\end{tabular}

ANOVA* $^{*} p<0,05$

A análise dos dados permitiu verificar que, quanto ao peso corporal, os animais do grupo $\mathrm{R}$ foram aqueles que mais se aproximaram do grupo $\mathrm{N}$, muito embora tenha ocorrido uma significativa diminuição da massa corporal. Todavia, uma diminuição drástica referente a esse parâmetro ocorreu nos animais do grupo $D$.

Quanto aos demais parâmetros, exceto para o relativo à ingestão de ração, onde a diferença estatística entre os grupos $\mathrm{R}$ e $\mathrm{N}$ foi ligeiramente significativa, os dados demonstram uma equivalência entre esses grupos, ou seja, os parâmetros são muito semelhantes. Da mesma forma, os parâmetros observados para os 
animais do grupo $\mathrm{D}$ mantiveram-se muito aquém daqueles encontrados para os demais grupos.

Esses parâmetros metabólicos estão representados nas figuras de 6 a 10.

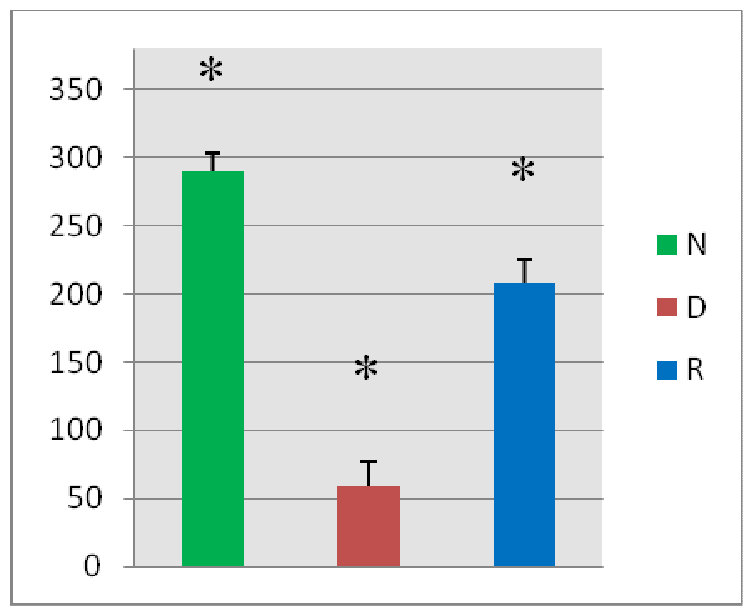

Figura 9 - Gráfico da média do peso corporal no final do experimento $(g) .\left(p<0,05^{\star}\right)$.

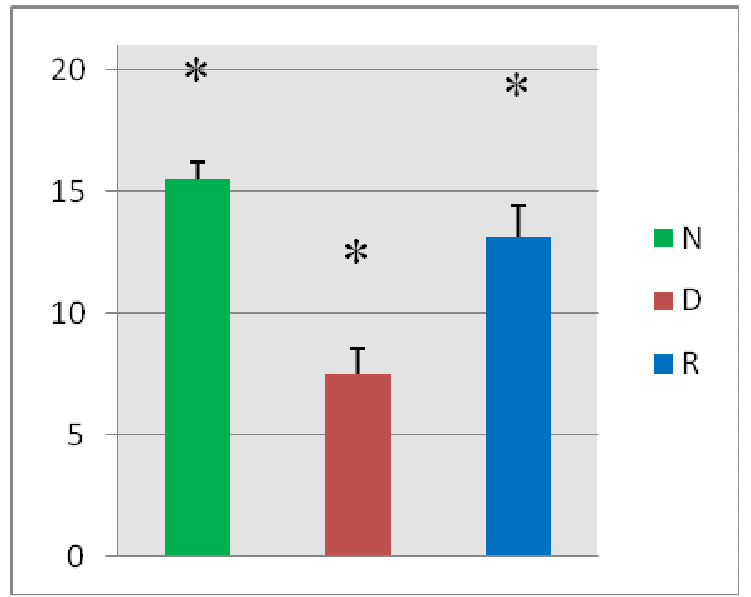

Figura 10 - Gráfico representando a média de ingestão de ração por dia e por grupo $(g) .\left(p<0,05^{*}\right)$. 


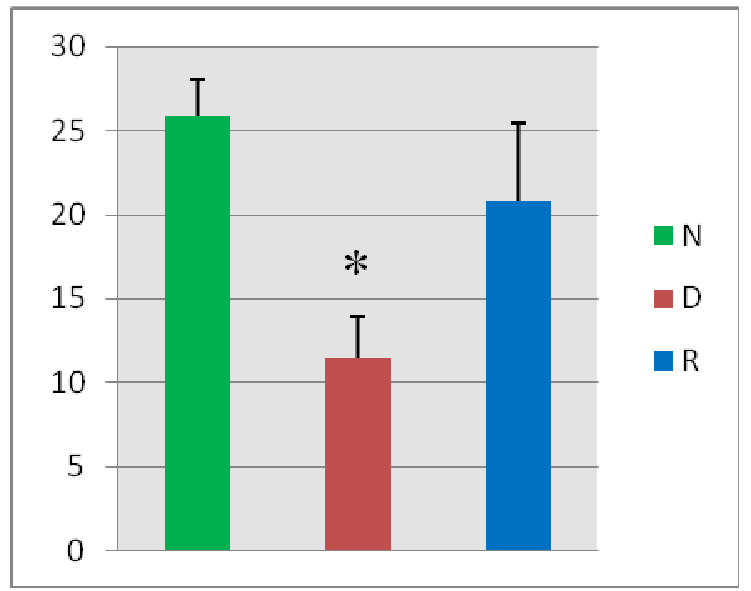

Figura 11 - Gráfico da média de ingestão de água por dia e por grupo (ml). $p<0,05^{\star}$.

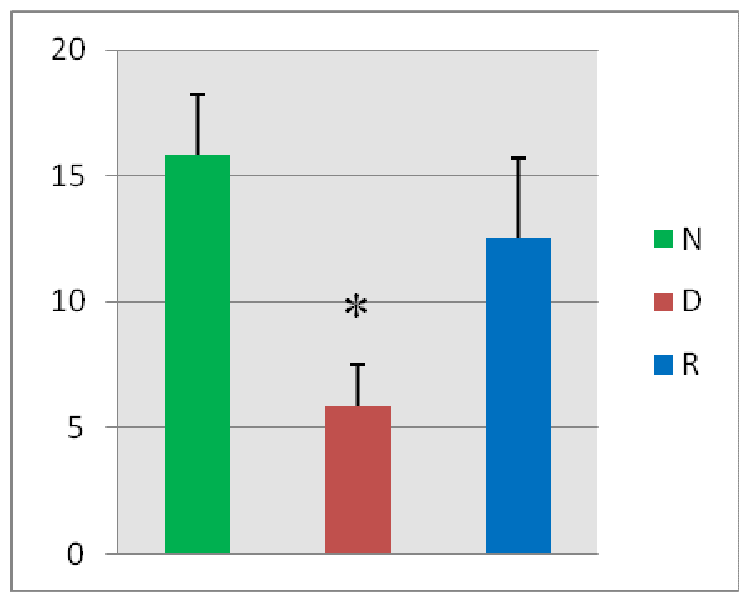

Figura 12 - Representação gráfica da média de eliminação de urina por dia e por grupo (g). $\mathrm{p}<0,05^{\star}$.

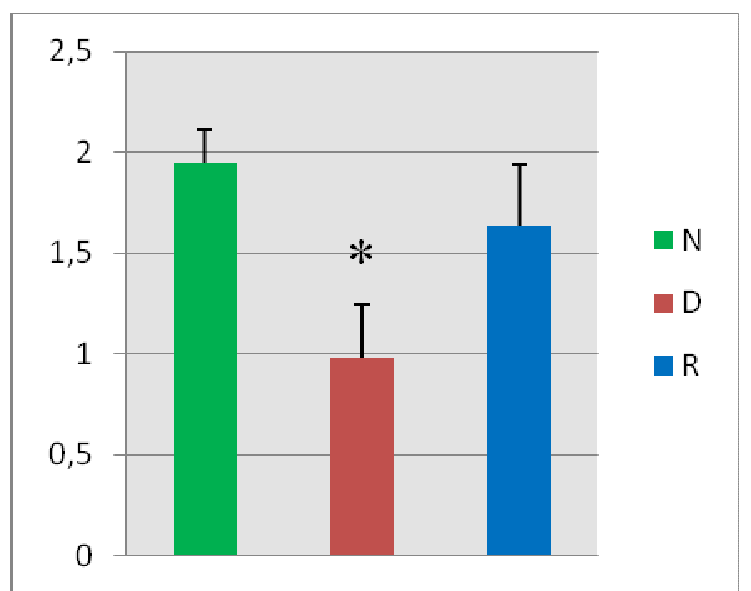

Figura 13 - Gráfico da média de eliminação de fezes por dia e por grupo (g). $\mathrm{p}<0,05^{\star}$. 
Com relação aos mesmos parâmetros exibidos anteriormente em uma análise ao final do experimento, as figuras $14,15,16,17$, e 18, exibem a evolução dos mesmos em uma análise temporal. É importante ressaltar que para esta análise com medidas repetidas (ANOVA) foram utilizados grupos de dados que, em gráfico, foram separados

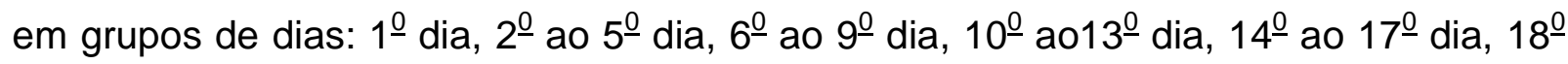

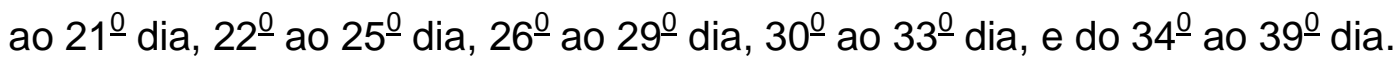

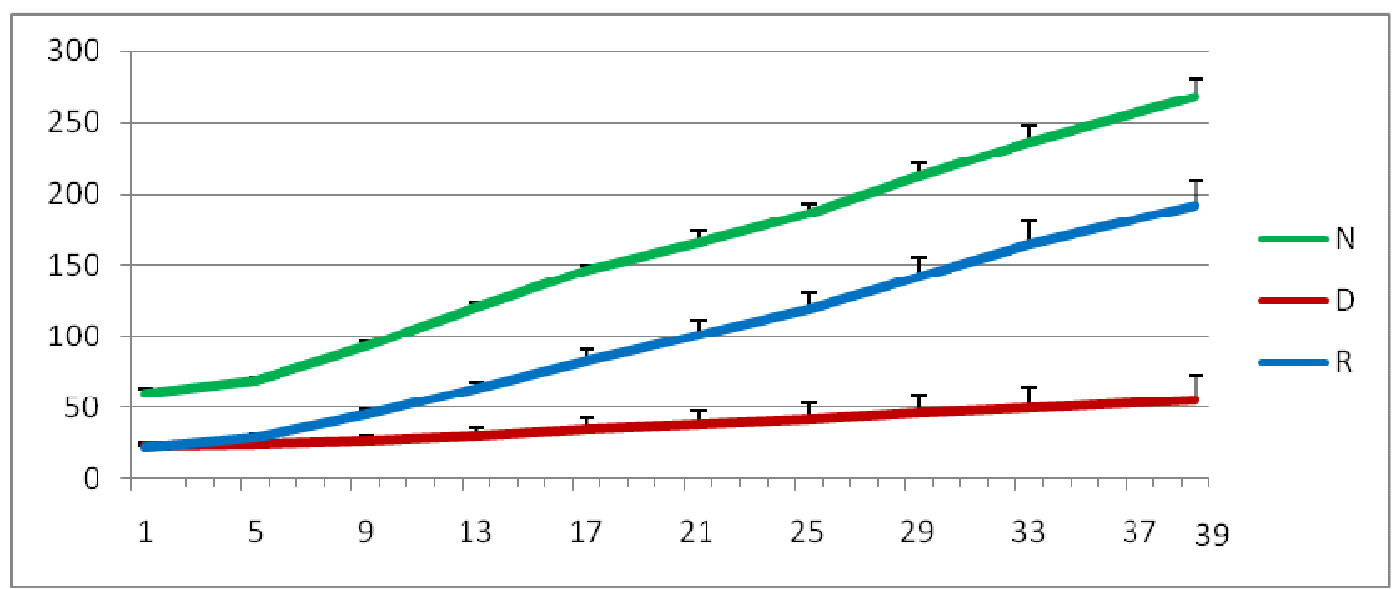

Figura 14 - Gráfico temporal do ganho de peso corporal dos animais mantidos em gaiolas metabólicas. $\mathrm{O}$ grupo $\mathrm{N}$ difere no ganho de peso de maneira significativa dia após dia, enquanto que o grupo $\mathrm{D}$ só obtém diferença estatística a partir do $8^{0}$ dia. $\mathrm{O}$ grupo $\mathrm{R}$ também ganhou peso de maneira significante logo após o $2^{\underline{0}}$ dia de experimento, e a partir do $4^{0}$ dia este grupo já apresentava diferença estatística com relação aos animais $D(p<0,05)$. 


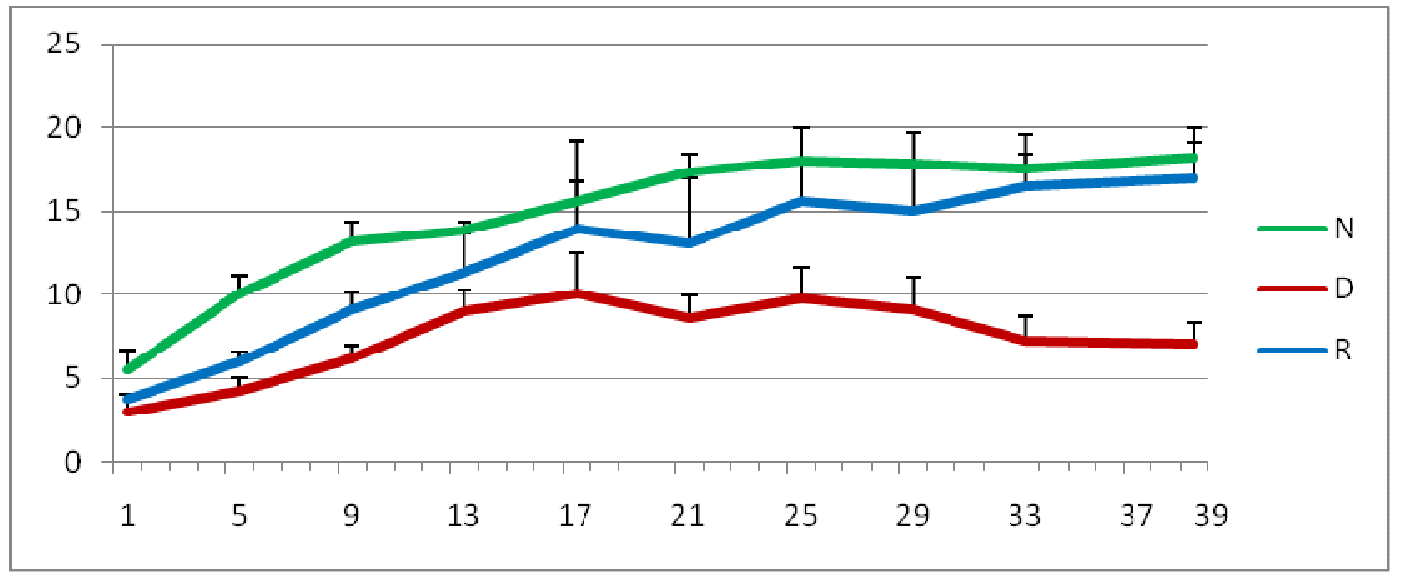

Figura 15 - Gráfico temporal da ingestão de ração dos animais mantidos em gaiolas metabólicas. A ingestão de alimento é crescente e significante no animal $\mathrm{N}$ a partir do $1^{0}$ dia de experimento até $010^{0}$ dia e, da mesma forma, o animal $\mathrm{R}$ tem aumento do consumo de ração a partir do $5^{-0}$ dia indo até o $14^{0}$ dia onde ambos os grupos tendem a alcançar um platô. Já o animal $\mathrm{D}$ tem aumento da ingestão significativa somente a partir do $10^{-\frac{0}{}}$ dia de experimento, aumentando até o $29^{-}$dia onde começa haver uma diminuição de ingestão. No $1^{0}$ dia de monitoramento todos os grupos são estatisticamente iguais $(p>0,05)$; no $2^{0}$ dia já se observa diferença estatística entre a ingestão dos animais $\mathrm{N}$ em relação aos $\mathrm{D}$, e o grupo $R$ somente se diferencia dos animais $D$ a partir do $17^{0}$ dia de experimento $(\mathrm{p}<0,05)$.

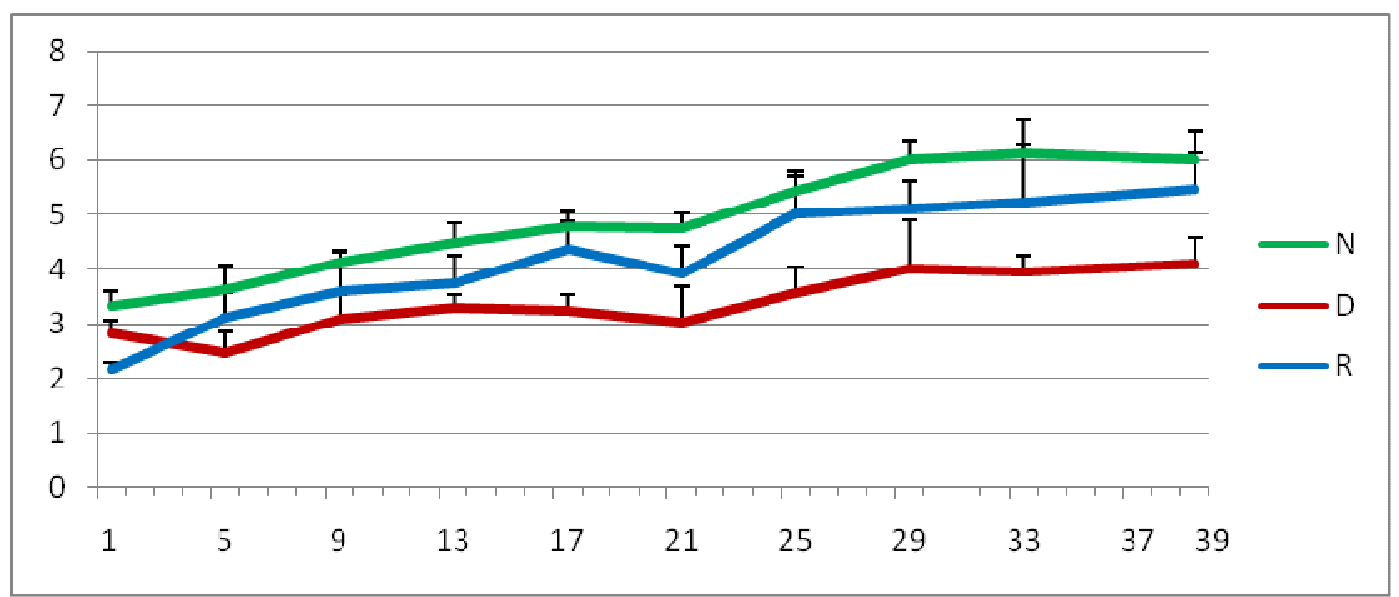

Figura 16 - Gráfico temporal da ingestão de água dos animais mantidos em gaiolas metabólicas. $\mathrm{O}$ animal $\mathrm{N}$ aumenta seu consumo de água a partir do $10^{\underline{0}}$ até $025^{0}$ dia de monitoramento de maneira significativa e, a partir deste dia, alcança um platô. Já os animais do grupo $\mathrm{R}$ tem aumento do consumo de água significante do $1^{\underline{0}}$ ao $22^{0}$ dia de monitoramento e, a partir deste, assim como os animais N, chegam a um platô. Somente a partir do $25^{0}$ dia de monitoramento é que os animais $D$ apresentam aumento significativo no consumo de água. No início, os animais $\mathrm{N}$ e $\mathrm{D}$ não diferem entre si quanto a este parâmetro, sendo ambos diferentes do $\mathrm{R}$ que, já no $2^{0}$ dia não difere dos animais $\mathrm{N}$ e, após o $14^{0}$ dia, tanto os animais $\mathrm{R}$ quanto os $\mathrm{N}$ são estatisticamente diferentes do grupo $D(p<0,05)$. 


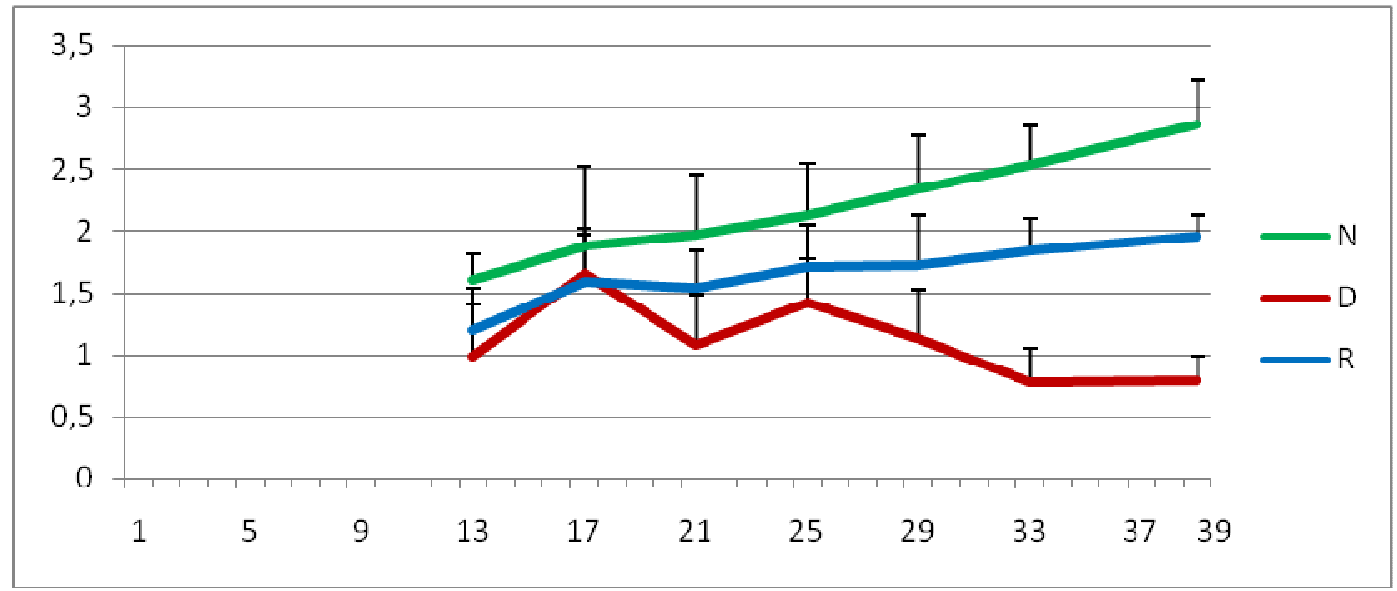

Figura 17 - Gráfico temporal da eliminação de fezes dos animais mantidos em gaiolas metabólicas. Nesta análise observou-se que os animais $\mathrm{N}$ diferenciaram-se dos animais $\mathrm{D}$ a partir do $18^{0}$ dia de monitoramento e, a partir do $30^{0}$ dia, todos os grupos mantiveram diferenças estatísticas de forma decrescente: $N-R-D$. Por limites técnicos da gaiola e/ou fezes pastosas dos animais, esta avaliação começou a partir do $13^{\underline{0}}$ dia, pois não houve dados o bastante para concretizar significâncias estatísticas.

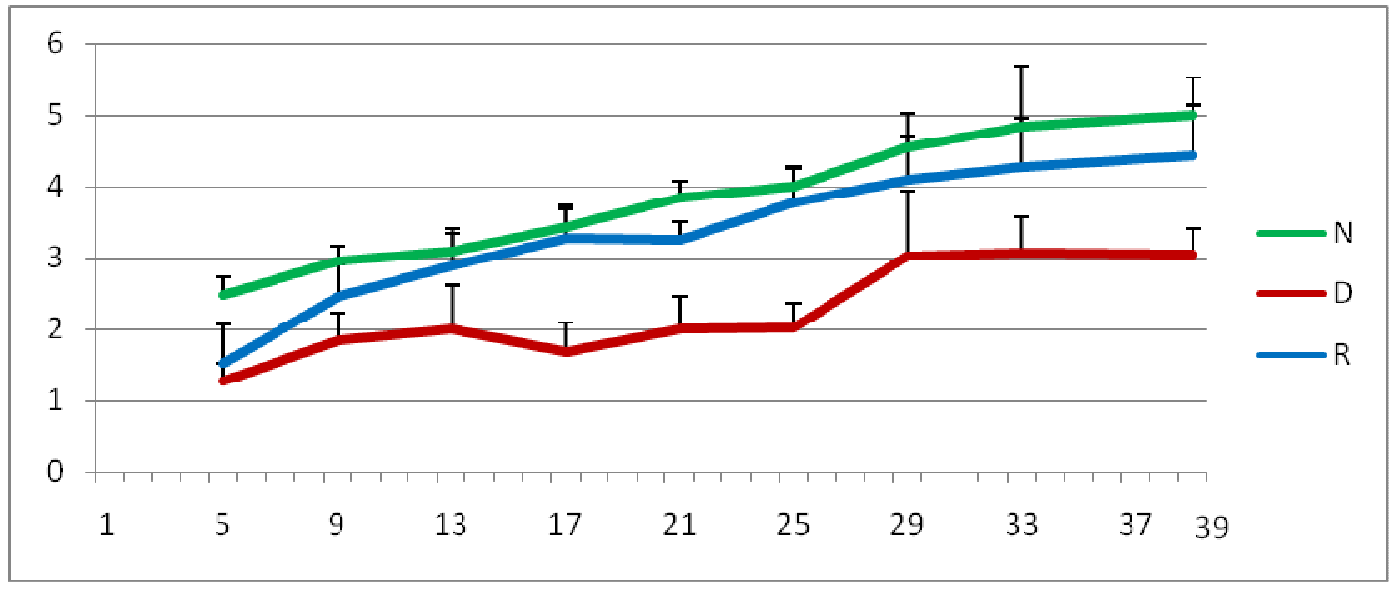

Figura 18 - Gráfico temporal da eliminação de urina dos animais mantidos em gaiolas metabólicas. $\mathrm{O}$ animal $\mathrm{N}$ apresentou aumento da excreção de urina significante a partir do $14^{0}$ até o $26^{0}$ dia, sendo a partir daí não mais significativo. $O$ animal $D$ tem um leve aumento significativo no período entre $25^{0}$ e $29^{-}$dia, não havendo depois disso significância entre os dias. $O$ animal $R$ apresenta desde o início um aumento na excreção de urina ( $5^{-}$dia), chegando até $022^{0}$ dia e, então não mais revela significância estatística. A relação entre estes grupos é que o animal $\mathrm{N}$ sempre elimina mais urina que $\mathrm{o}$ animal $\mathrm{D}$ e, portanto, sempre é diferente estatisticamente, enquanto o grupo $R$ é igual ao grupo $D$ até $013^{0}$ dia sendo diferente a partir deste dia $(p<0,05)$. O R é diferente do $N$ até $05^{0}$ dia e a partir do $6^{0}$ já são iguais com relação a este parâmetro, ou seja, não exibem diferença estatística $(p>0,05)$. 
Considerando os dados temporais anteriormente descritos, é possível afirmar que os animais $\mathrm{R}$, na maioria dos parâmetros, se comportam como os animais $\mathrm{N}$ ou já não exibem os mesmos parâmetros que os animais $D$ a partir do período compreendido entre o $14^{0}$ e $17^{0}$ dia de monitoramento. A exemplo disso, os parâmetros eliminação de urina, ingestão de água e ingestão de ração são diferentes estatisticamente dos animais $\mathrm{D}$ a partir do $13^{\underline{0}}, 14^{0}$ e $17^{0}$ dia respectivamente. Deste período em diante, estes animais adquirem um comportamento metabólico como os dos animais $\mathrm{N}$, enquanto os animais D ou mantêm ou decrescem em seus parâmetros.

Para fundar comparações funcionais dos animais perante os dados metabólicos, estão expressas na tabela 3 relações entre estes parâmetros analisados nos diferentes grupos.

Tabela 3 - Descrição das relações entre as médias diárias metabólicas ( \pm DP).

\begin{tabular}{lccc}
\hline \multicolumn{1}{c}{ Parâmetros } & Nutridos & Desnutridos & Renutridos \\
\hline \%Ingestão/peso corporal & $10 \pm 0,2$ & $21 \pm 4^{*}$ & $14 \pm 1$ \\
\%Fezes/ingestão & $12 \pm 0,8$ & $14 \pm 4$ & $11 \pm 1$ \\
Água/peso corporal (ml/g) & $0,16 \pm 0,01$ & $0,29 \pm 0,04^{*}$ & $0,21 \pm 0,04$ \\
\%Urina/água consumida & $60,0 \pm 3,4$ & $52,5 \pm 3,5^{*}$ & $59,9 \pm 3,9$ \\
& & & \\
\hline
\end{tabular}

Ao se avaliar as razões Ingestão/peso corporal e Água/peso corporal, verifica-se que os animais do grupo $\mathrm{D}$ exibiram uma porcentagem elevada, destacando-se dos 
demais grupos ( $\mathrm{N}$ e $\mathrm{R}$ ) que não diferiram estatisticamente entre si. Houve uma paridade entre os grupos (N, D, R) quanto à razão Fezes/ingestão, enquanto que, relativamente à razão Urina/água consumida, o grupo $\mathrm{D}$ revelou uma discreta diminuição quando comparado aos grupos $\mathrm{N}$ e $\mathrm{R}$, que se mostraram semelhantes estatisticamente.

A representação gráfica dessas razões são verificadas nas figuras 19 a 22 .

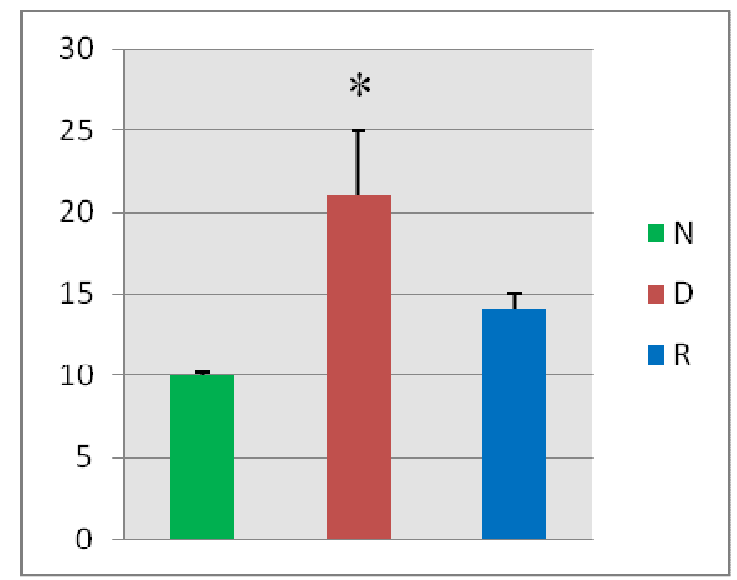

Figura 19 - Gráfico da relação diária entre a ingestão de ração e peso corporal nos grupos experimentais (ml/g). $\mathrm{p}<0,05^{*}$.

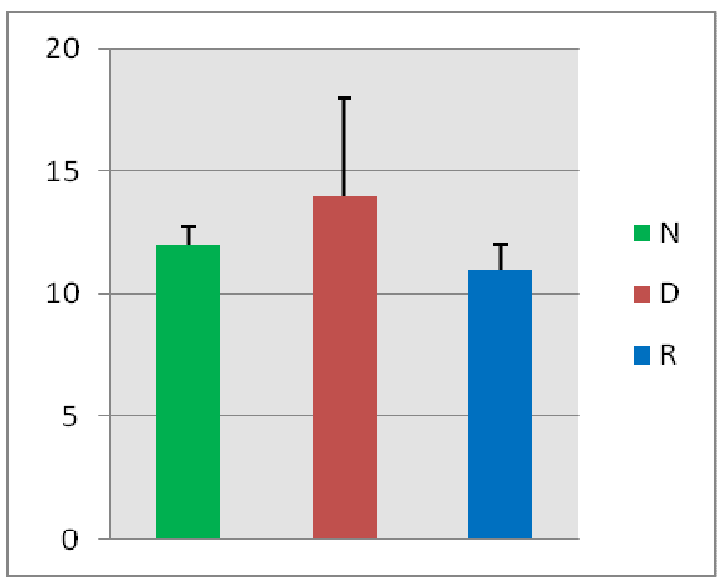

Figura 20 - Gráfico da porcentagem diária de eliminação de fezes por ingestão de ração nos grupos experimentais (\%). 


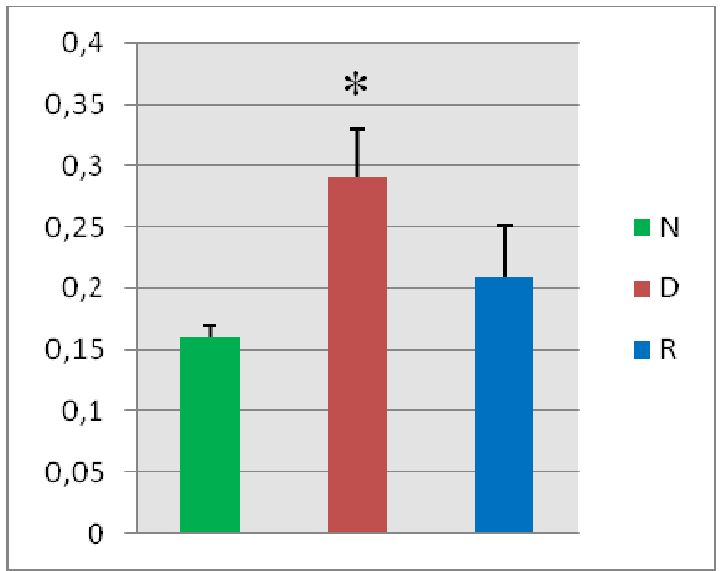

Figura 21 - Gráfico da relação diária entre ingestão de água e peso corporal nos grupos experimentais $(\mathrm{ml} / \mathrm{g}) \cdot \mathrm{p}<0,05^{*}$.

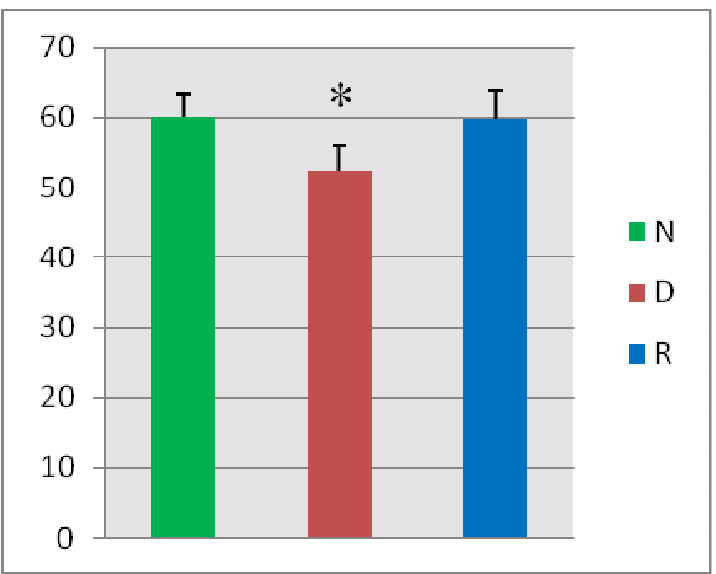

Figura 22 - Gráfico da relação diária entre a eliminação de urina e ingestão de água nos grupos experimentais $(\mathrm{ml} / \mathrm{g}) . \mathrm{p}<0,05^{*}$. 
A avaliação do desenvolvimento da massa corporal dos animais dos grupos N, D e $\mathrm{R}$, foi feita através da razão entre dois pesos estabelecidos da seguinte forma:

O peso 1 foi aquele obtido quando o animal, com 21 dias de vida, iniciava o experimento metabólico, onde permaneceu até completar 60 dias de vida, quando então se determinou, momentos antes da eutanásia o peso 2 , ou seja, obtido no $39^{\circ}$ dia do experimento. Desta forma, como se comprova na figura 15, ocorreu uma razão de 9,1 para o grupo $R ; 4,7$ para o grupo $\mathrm{N}$ e de 2,4 para o grupo $\mathrm{D}$, com $p<0,001$ entre os grupos.

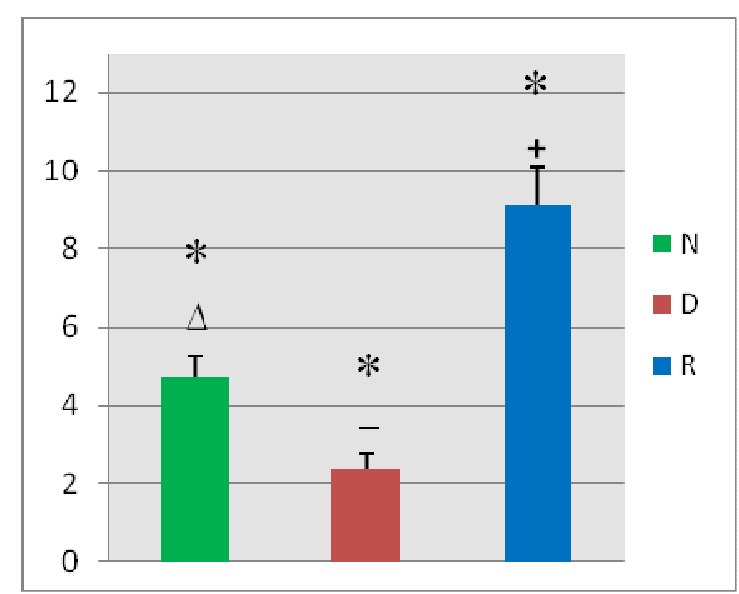

Figura 23 - Gráfico da média da relação entre massa corporal final e inicial no período experimental. (+ representa 0 maior resultado, - representa o menor resultado, $\Delta \circ$ resultado médio. $\left.p<0,05^{*}\right)$. 


\subsection{Aspectos Qualitativos}

\subsubsection{Macro-mesoscópico}

Durante o procedimento de retirada dos timos dos animais, alguns aspectos referentes à sua morfologia e/ou suas estruturas anexas durante a dissecção devem ser ressaltadas. Nos animais do grupo $\mathrm{N}$ e $\mathrm{R}$ o procedimento seguiu como referido no item (3.2) com relação à morfologia descrita e as estruturas associadas. Já nos animais D se encontrava uma pele delgada e com pouca gordura subcutânea; sua musculatura era hipotrofiada sendo, na região do abdome, translúcida de tal modo que as vísceras podiam ser vistas a olho desarmado. Além destas características, as costelas eram facilmente fraturadas no processo de abertura do tórax comparativamente aos animais $\mathrm{N}$ e R. Sobretudo nos animais $\mathrm{D}$, a quantidade de tecido conjuntivo depositado em torna da glândula era muito maior do que o visto para os outros grupos, dificultando a visualização do órgão sendo necessária uma dissecção mais minuciosa.

Os timos dos diversos grupos (N, D, R) diferiram, comparativamente, nas suas dimensões, porém, a glândula mostrou-se bilobada em todos os casos. Relativamente ao aspecto macroscópico, muito embora não se tenha determinado as medidas de comprimento, largura e espessura do órgão, o mesmo permitiu corroborar com os dados obtidos para o peso, sendo os timos dos animais $\mathrm{N}$ e $\mathrm{R}$ muito semelhantes. Da mesma forma, o timo dos animais $\mathrm{D}$ apresentou-se muito menor do que o verificado para os animais $\mathrm{N}$ e $\mathrm{R}$ (Figura 24). 


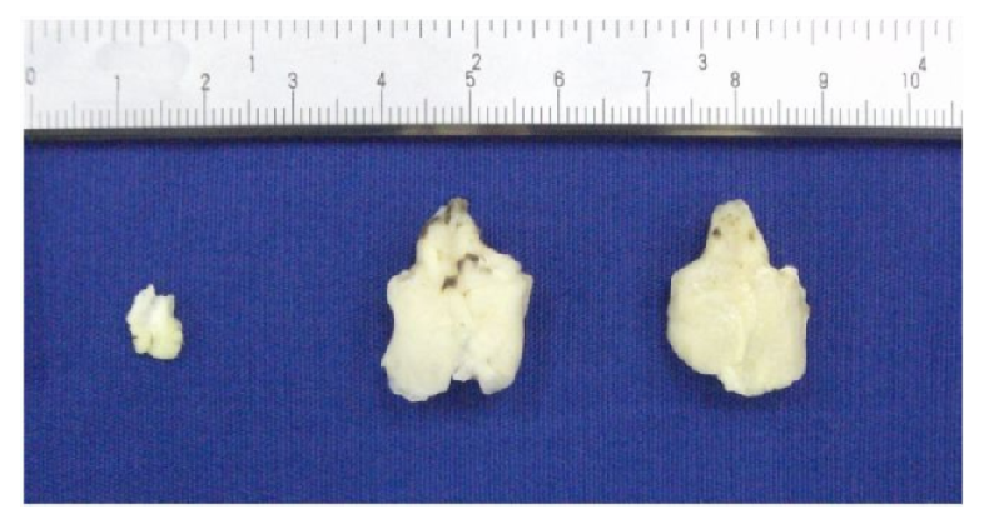

Figura 24 - Fotografia do timo de ratos de 60 dias. Da esquerda para a direita estão dispostos os timos de animais dos grupos desnutrido (D), nutrido $(\mathrm{N})$ e renutrido $(\mathrm{R})$. Notar que o tamanho do timo $\mathrm{D}$ é muito menor do que o dos espécimes $\mathrm{N}$ e R que, aparentemente, não apresentam diferenças entre si.

Sob lupa, verificou-se o predomínio de lóbulos grandes nos timos dos animais $\mathrm{N}$ e

$\mathrm{R}$; nos timos dos animais $\mathrm{D}$, poucos destes estiveram presentes. Ao se analisar a superfície lobular, evidenciou-se um aspecto prevalentemente liso nos animais dos grupos D e R, destacando-se da superfície subdividida em compartimentos, conferindo um aspecto de "malha" aos lóbulos tímicos dos animais do grupo N (Figura 25).
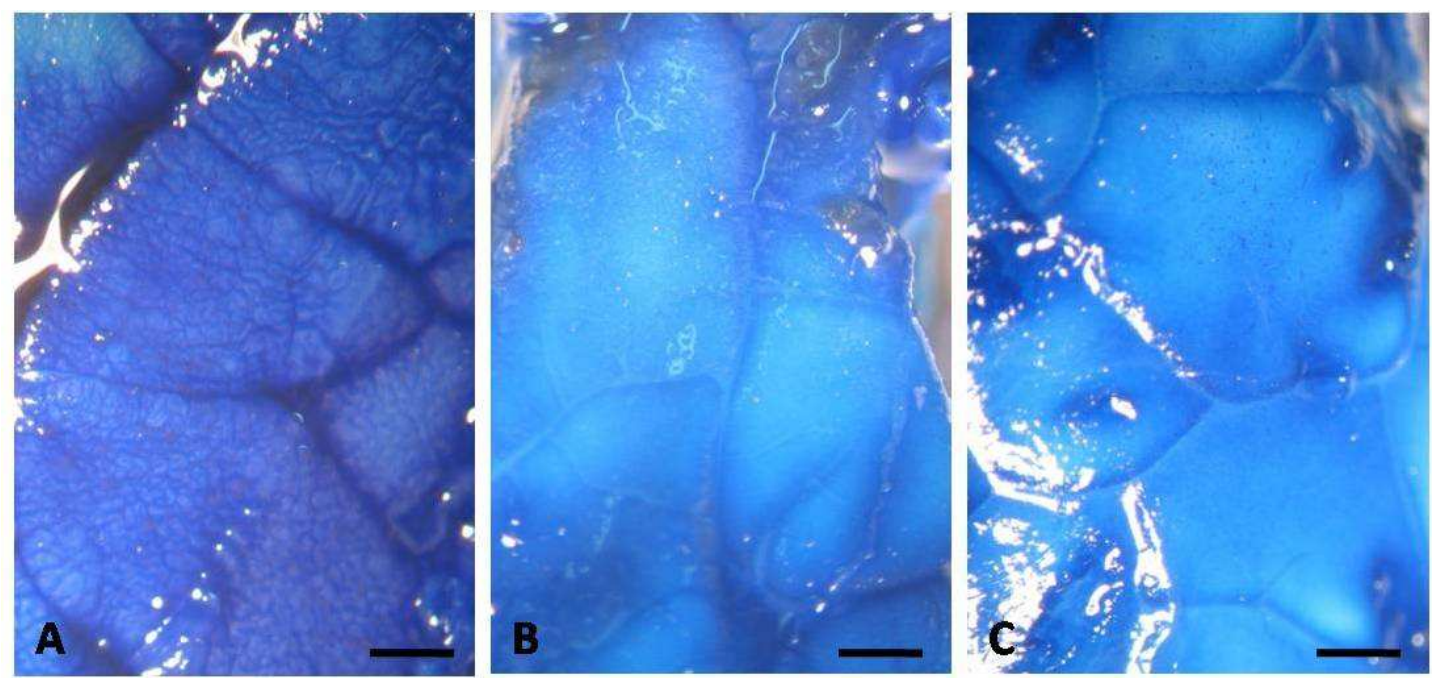

Figura 25 - Fotografia da superfície do timo de ratos N (A); D (B) e R (C). Notar a superfície lisa dos lóbulos dos animais $\mathrm{D}$ e $\mathrm{R}$ e o aspecto marcado da superfície dos lóbulos dos animais do grupo N. (Azul de toluidina. A-C: 0,2cm) 


\subsubsection{Microscópico}

Sob microscopia de luz, foram avaliados, para todos os grupos (N, D R), os seguintes aspectos do parênquima tímico: cápsula, septos interlobulares, lóbulos tímicos, região cortical e região medular com seus timócitos, vasos interlobulares, vasos centrolobulares, e corpúsculos tímicos.

Em todos os grupos a cápsula tímica se apresentava envolvendo o órgão, invaginando entre os lóbulos para formar os septos interlobulares. Nos animais do grupo $\mathrm{N}$ notou-se que a cápsula tímica, de espessura razoável, apresentava reentrâncias de pouca profundidade nos lóbulos tímicos, mas o suficiente para conferir ao córtex um aspecto crenado (Figura 26, A). Apesar do timo dos animais $\mathrm{R}$ exibirem uma cápsula de espessura semelhante à dos animais $\mathrm{N}$, as reentrâncias não foram observadas, tendo um aspecto compatível ao verificado para os timos dos animais $D$ (Figura 26).
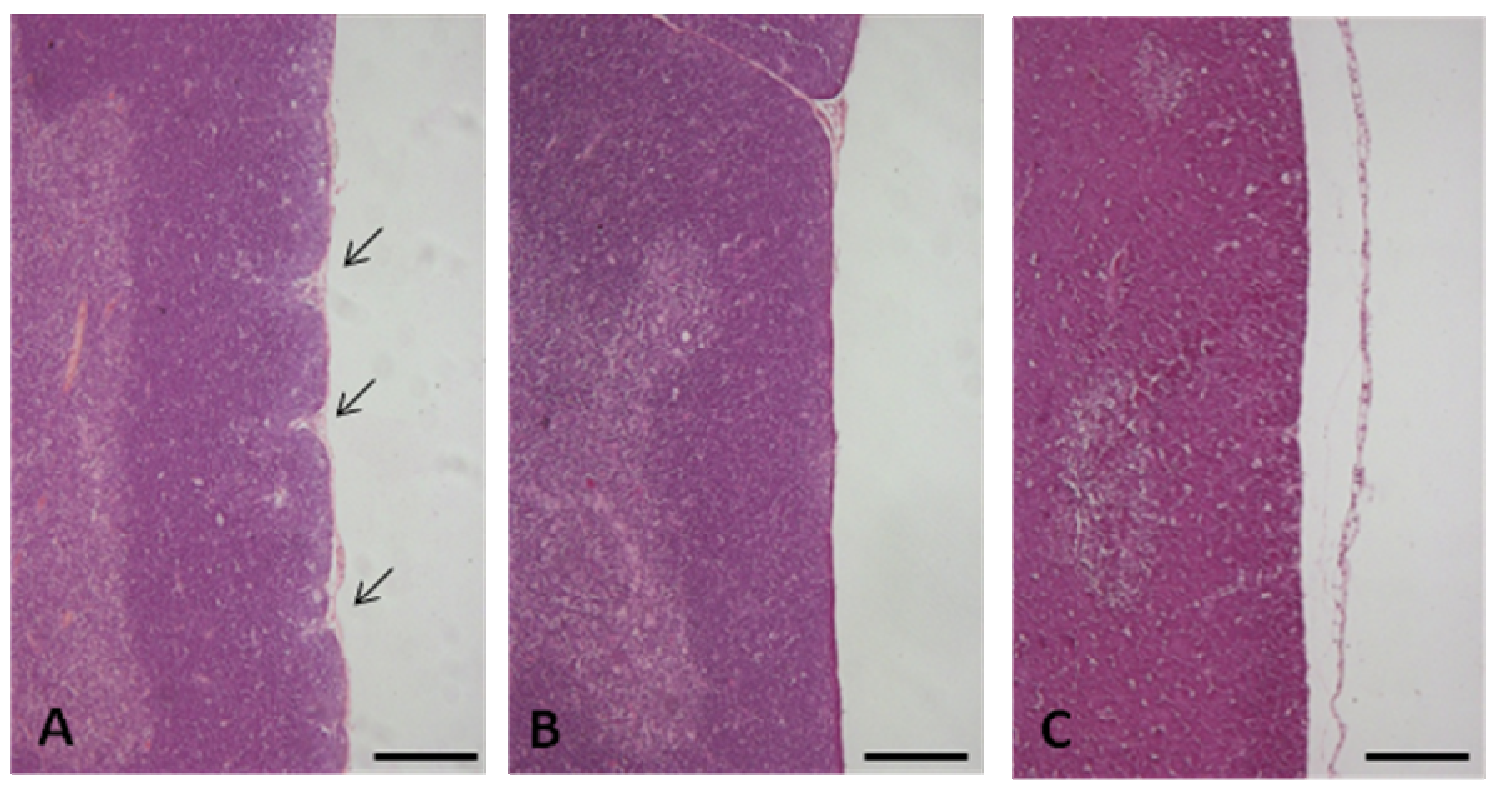

Figura 26 - Fotomicrografia da cápsula tímica de ratos N (A); D (B) e R (C). Notar as reentrâncias da cápsula na superfície do timo de animais $\mathrm{N}$ (setas $\mathrm{A}$ ), e a superfície lisa dos lóbulos dos animais D e R. (HE. A-C: $200 \mu \mathrm{m}$ ) 
A cápsula tímica demonstrou-se relativamente mais espessa e melhor arranjada nos animais $\mathrm{N}$ e $\mathrm{R}$, porém, nos três grupos (N, D e R) os septos interlobulares estavam dispostos no parênquima tímico dividindo os lóbulos adjacentes, proporcionando passagem de vasos interlobulares para o interior da glândula (Figura 27). Esses vasos foram encontrados nos grupos $\mathrm{N}$ e $\mathrm{R}$, em tamanho e número relativamente maior do que nos animais do grupo D (Figura 27).

Em análise em microscópio eletrônico de varredura, as informações citadas no parágrafo anterior são confirmadas e vistas sob aspecto tridimensional. Ainda comentando sob esta análise, os animais dos grupos $\mathrm{N}$ e $\mathrm{R}$ exibiram uma porção maior de fibras interlobulares comparativamente aos animais do grupo D (Figura 28).

Sob luz polarizada, notou-se a presença de fibras colágenas dos tipos I e III, distribuídas de maneira diferente na cápsula e nos septos interlobulares de acordo com o grupo estudado. Desta forma, nos timos dos animais do grupo N, muito embora tenha ocorrido um predomínio das fibras colágenas do tipo III principalmente na região capsular do órgão, uma quantidade expressiva de fibras do tipo I estava presente nos septos interlobulares e na cápsula tímica, porém, principalmente na parede dos vasos interlobulares. Nos animais do grupo D, apesar da marcação tênue, foi nítido o predomínio das fibras colágenas do tipo I nessas estruturas (Figura 29). Já nos animais do grupo $\mathrm{R}$, houve predomínio de fibras colágenas do tipo III, com razoável quantidade de fibras do tipo I tanto na região capsular quanto na região interlobular, se assemelhando ao aspecto visto para os animais do grupo $\mathrm{N}$. 


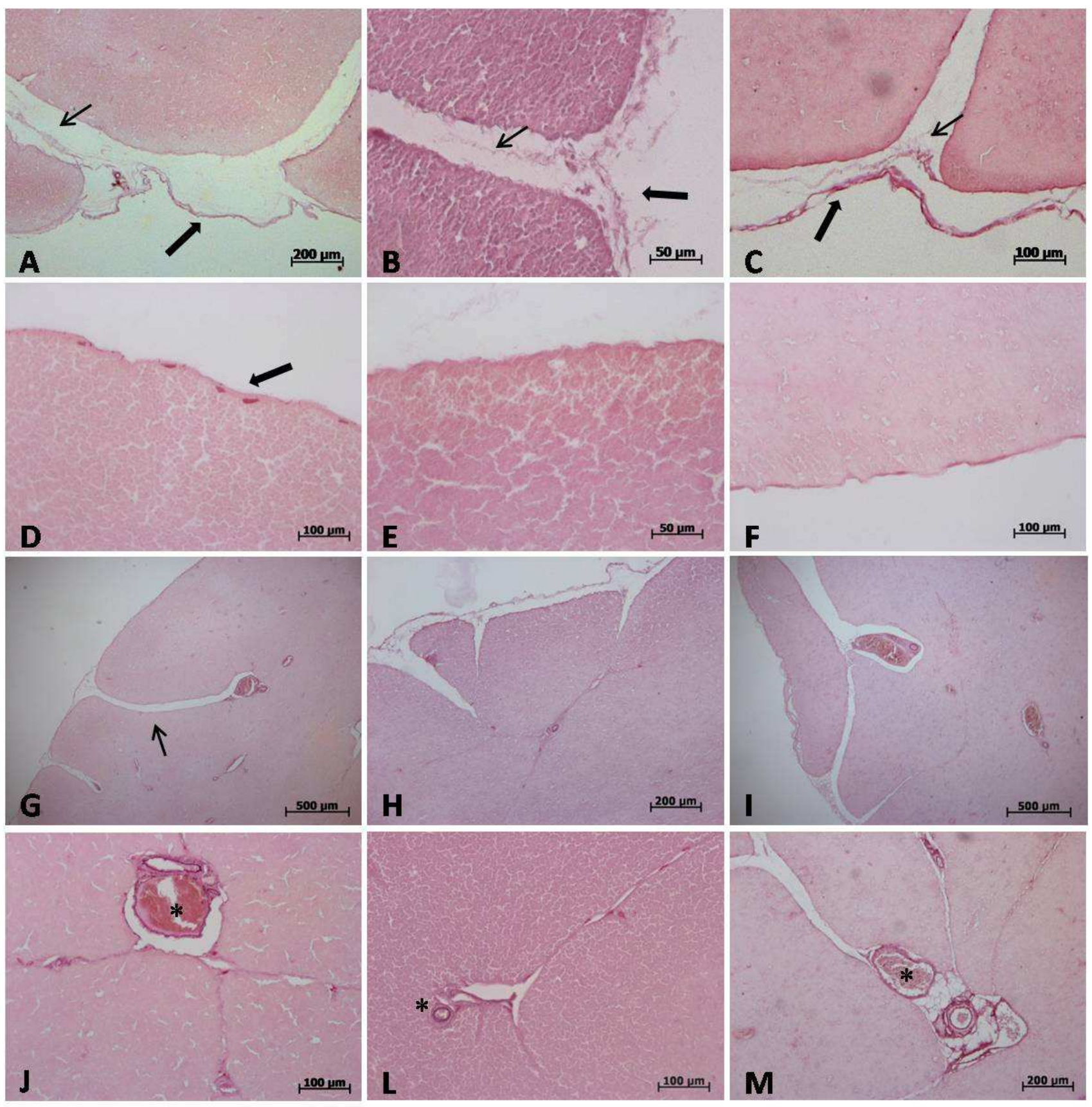

Figura 27 - Fotomicrografia da cápsula, septo interlobular e vasos interlobulares de timo de ratos dos grupos N (A, D, G, J); D (B, E, H, L) e R (C, F, I, M). Notar a distribuição das fibras elásticas e a espessura da cápsula (seta espessa), sua invaginação para o interior da glândula separando os lóbulos (seta delgada) e o relativo tamanho dos vasos interlobulares (*). (Weigert contra-corado com Van Giensen) 

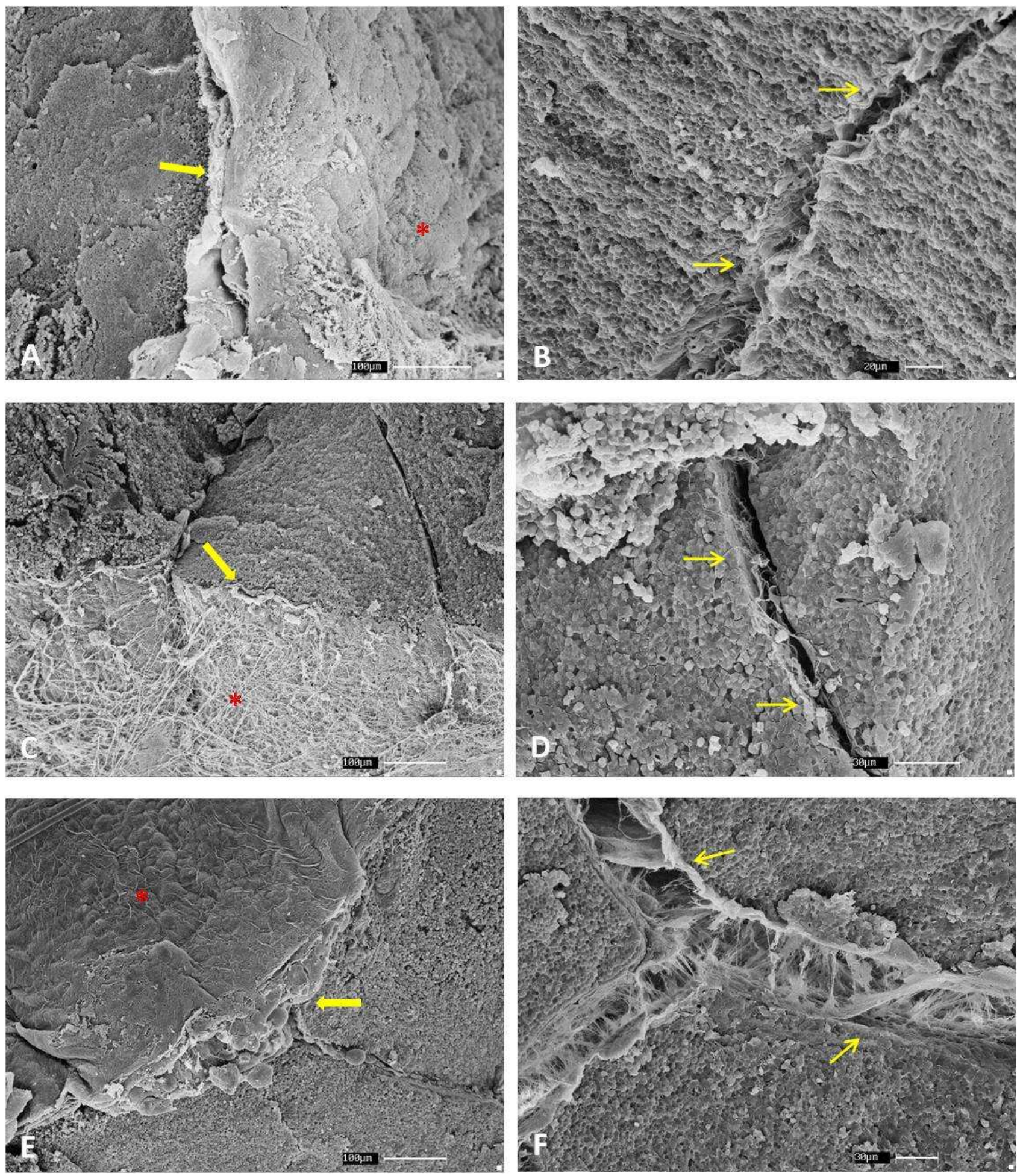

Figura 28 - Eletronmicrografias de varredura do timo de ratos dos grupos N (A-B); D (C-D) e R (EF). Observe 0 aspecto da superfície da cápsula tímica (*) e sua relativa espessura (seta espessa), além os septos interlobulares (seta delgada) com suas destacadas fibras interlobulares. 


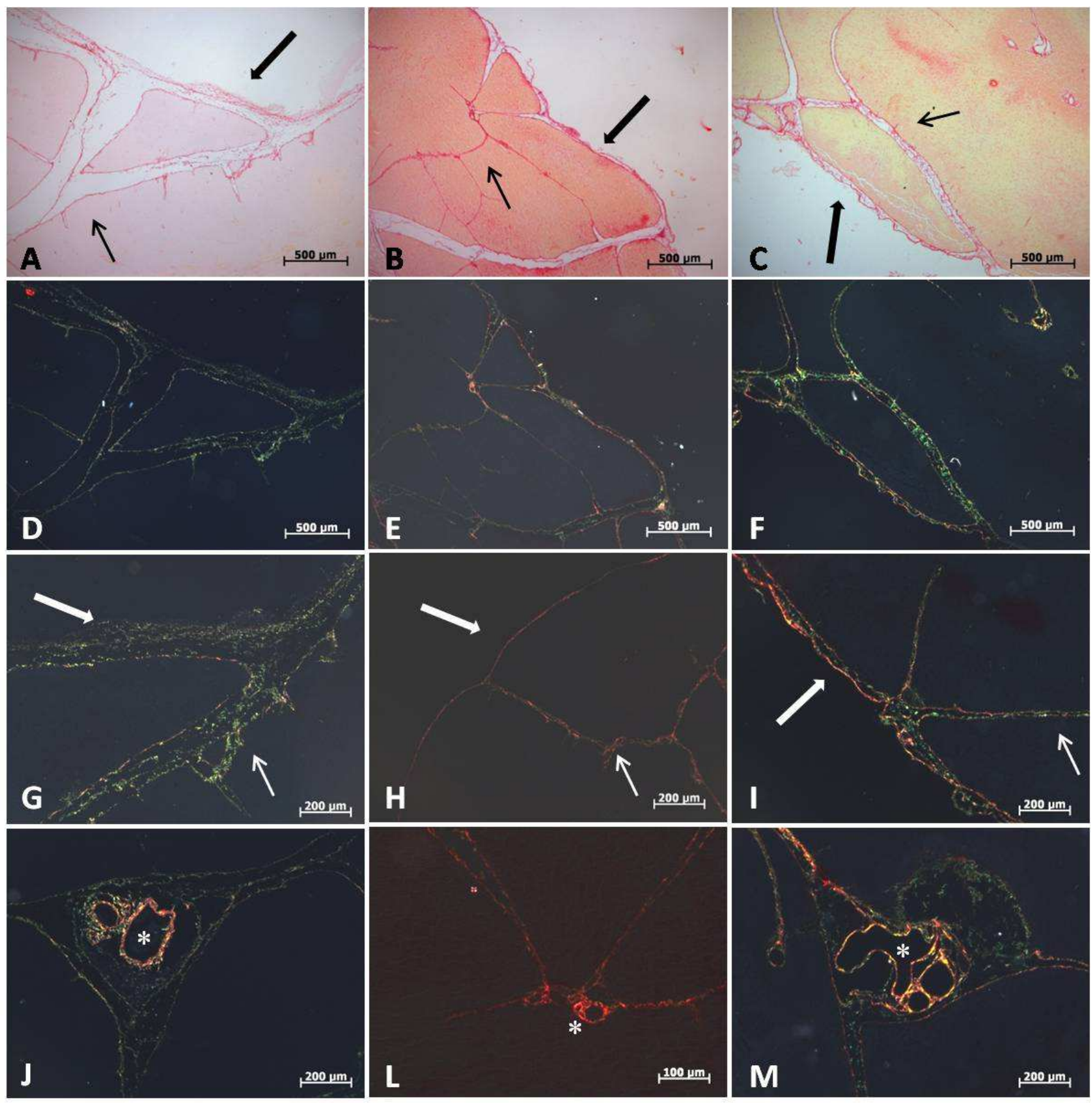

Figura 29 - Fotomicrografia de timo de ratos. N (A, D, G, J); D (B, E, H, L) e R (C, F, I, M). Notar na cápsula (seta espessa) e septos interlobulares (seta delgada), as fibras colágenas dos tipos I (vermelho, amarelo, laranja) e III (verde). (*) - vasos interlobulares. (A-C - Picro-sirius, D-M Picro-sirius sob luz polarizada). 
O parênquima tímico dos grupos $\mathrm{N}$ e $\mathrm{R}$ tiveram como característica peculiar os inúmeros lóbulos perfeitamente distinguíveis (Figura 30, A e E) arranjados de forma contínua entre si, exibindo uma clara distinção entre o CT e MT, bem como o limite bem definido entre estas duas regiões (Figura 30, B e D). Comparativamente, quanto a esses aspectos, além da diminuição do tamanho e da quantidade de lóbulos (Figura 30, C), os timos dos animais do grupo D exprimiram ampla depleção do CT em relação aos outros grupos, e uma desorganização no limite córtex-medula, não sendo bem esclarecida a sua demarcação (Figura 30, D).

Em uma observação minuciosa do CT, deparou-se com timócitos ou linfócitos T em processo de apoptose em ambos os grupos. Foi verificado tal fenômeno em poucas células da região cortical dos timos dos animais $\mathrm{N}$ e $\mathrm{R}$ (Figura 31, A e E), porém, no grupo D este estava presente em quantidade exacerbada (Figura 31, C e D), tanto que, na região medular, também foram encontradas algumas células em apoptose.

Vasos centrolobulares de diferentes calibres e, representando diferentes comprimentos, estavam cortando o parênquima tímico no CT, porém, principalmente na MT dos animais dos grupos $\mathrm{N}$ e $\mathrm{R}$; nos animais do grupo $\mathrm{D}$, poucos vasos foram detectados no $\mathrm{CT}$, restringindo-se à $\mathrm{MT}$ a presença dessas estruturas que, foram identificadas em quantidade e calibre menor em relação aos demais grupos (Figura 32). 

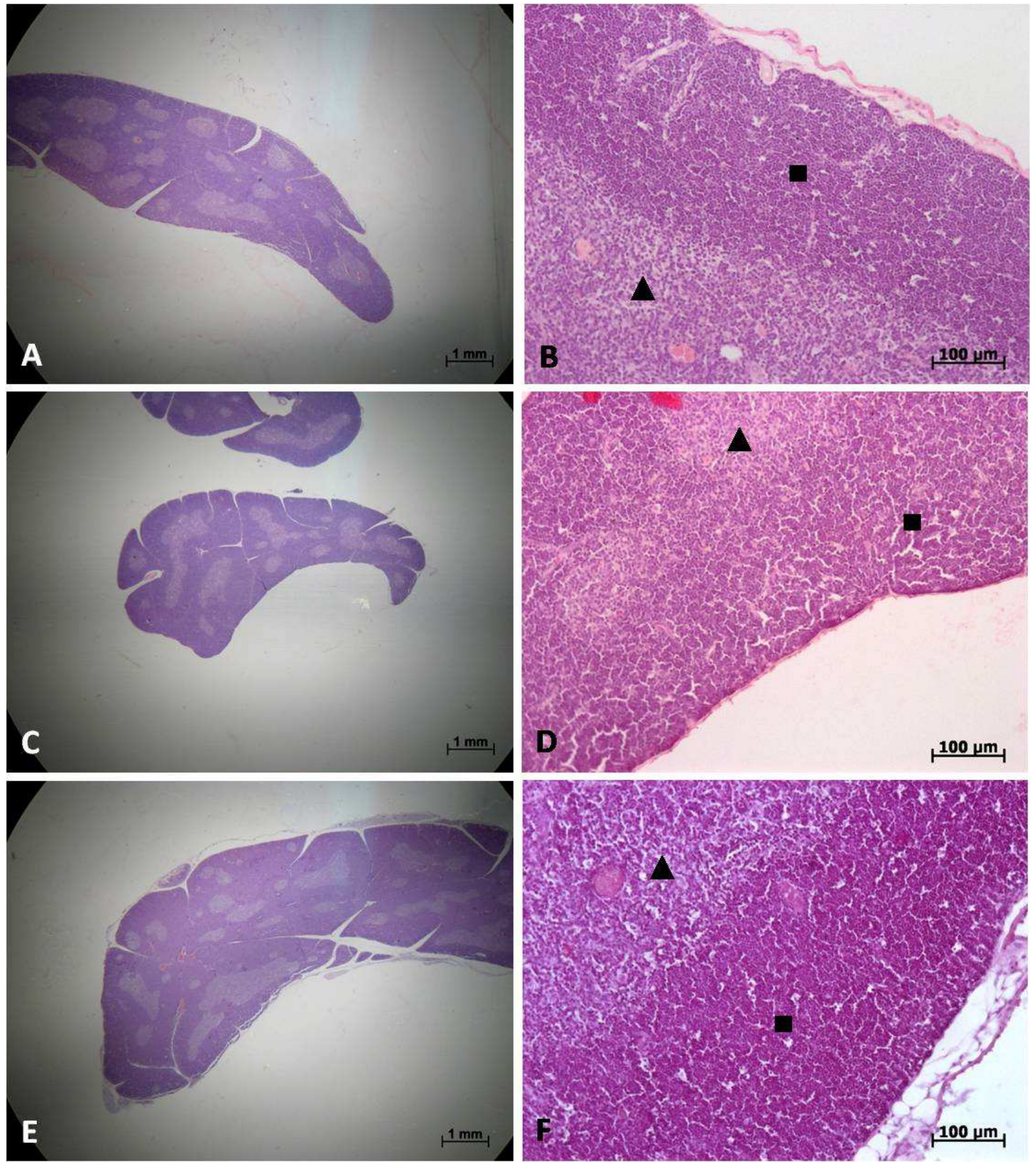

Figura 30 - Fotografia e fotomicrografia de timo de ratos. N (A-B); D (C-D) e R (E-F). Observar a organização dos lóbulos, a região cortical $(\mathbf{\square})$ e medular $(\mathbf{\Lambda})$. Notar o limite bem definido entre córtex e medula (B, F), e um limite desorganizado em (D). Veja como a coloração é mais intensa na região cortical devido à maior densidade de timócitos. (A,F - H.E.). 

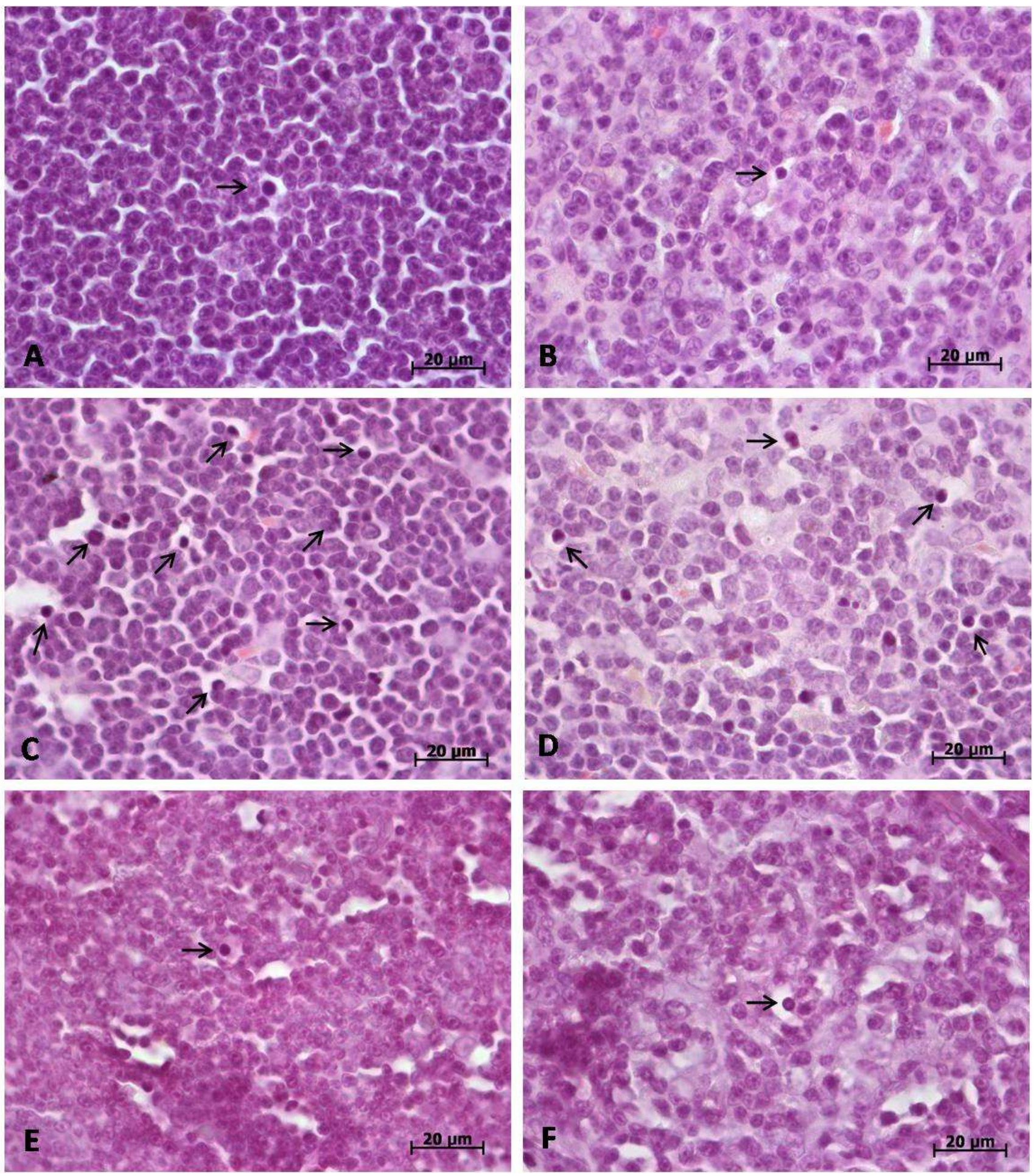

Figura 31 - Fotomicrografia do parênquima tímico de ratos N (A-B); D (C-D) e R (E-F). Posicionadas à esquerda estão as fotomicrografias do $\mathrm{CT}$ e à direita da $\mathrm{MT}$. Observe o relativo número de células em apoptose na região cortical dos timos de animais $\mathrm{N}$ e $\mathrm{R}(\mathbf{A}$ e E), e a ausência destes na região medular destes animais (B e F). Nos animais do grupo $D$ a visualização destas células em processo de apoptose é comparativamente maior tanto no CT quanto na MT (C e D). (A-F - H.E.). 

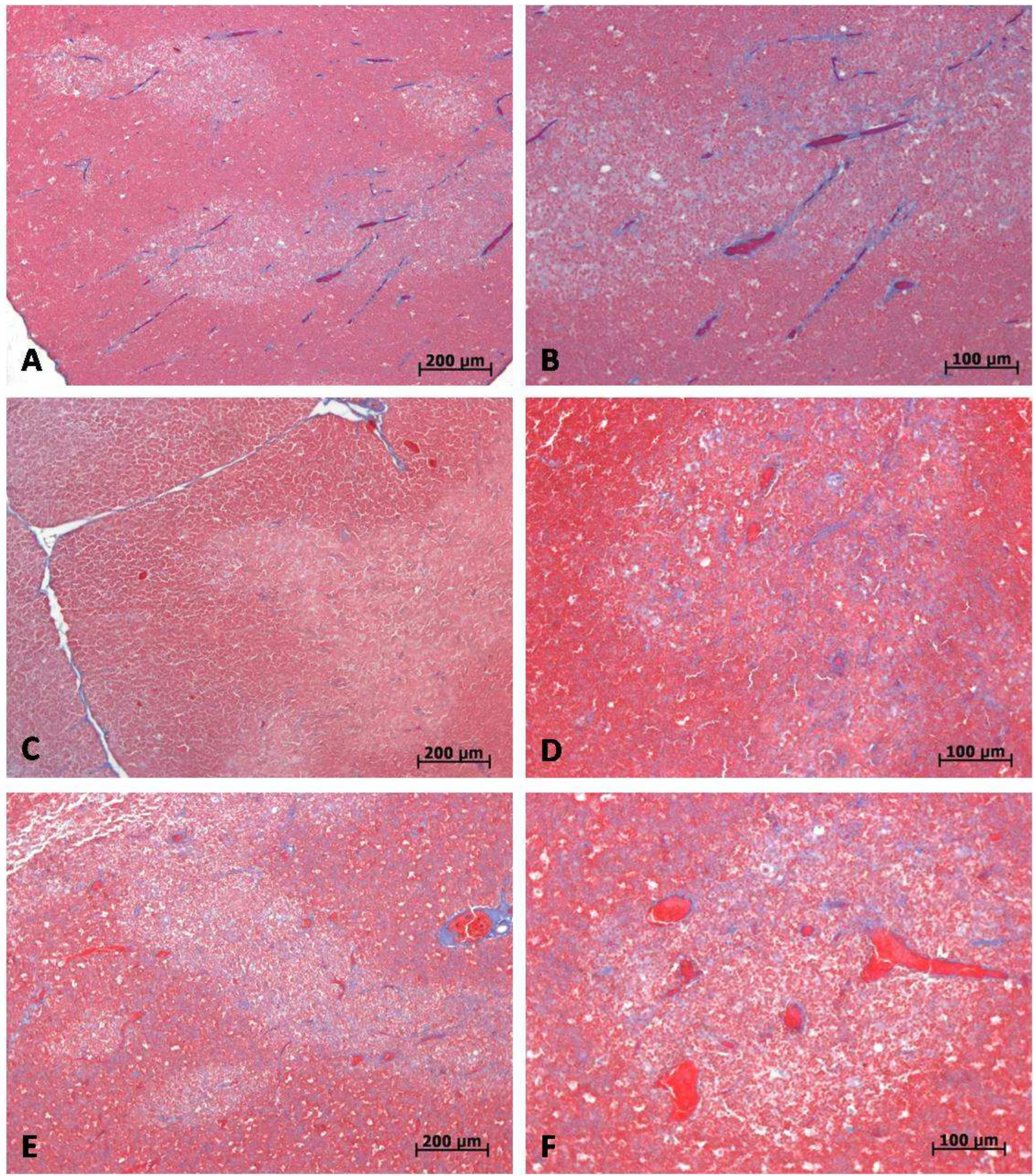

Figura 32 - Fotomicrografia da MT de timo de ratos N (A-B); D (C-D) e R (E-F). Timócitos medulares e vasos centrolobulares dispostos na medula tímica (A-F - Tricomio de Masson). 
Quanto aos corpúsculos tímicos, notou-se que os animais de ambos os grupos (N, D, e R) continham o tipo sólido e cístico (Figura 33). Entretanto, optou-se por descrevêlos em quatro categorias de acordo com suas características: juvenil (A), imaturo (B e C), maduro (D e F) e envelhecido (E). Na maioria das ocasiões se observava o tipo imaturo e maduro, sendo apenas visto em oportunidades singulares a presença de corpúsculos tímicos do tipo juvenil e envelhecido, principalmente para o grupo $\mathrm{D}$ e $\mathrm{R}$. Embora tenha se descrito e comentado sobre estas estruturas, poucas diferenças foram verificadas entre os grupos experimentais com relação a elas, sendo apenas marcante o número relativamente menor destas estruturas nos animais do grupo $D$.

As imagens da figura 34 exibem formações vacuolares encontradas entre os septos interlobulares, predominantemente próximo a cápsula tímica e/ou vasos interlobulares, do timo dos animais dos grupos N, D e R. Referente a esta observação, os animais do grupo $\mathrm{D}$ e $\mathrm{R}$ permitiam a visualização destes vacúolos facilmente, não sendo esta uma característica dos animais do grupo $\mathrm{N}$. 

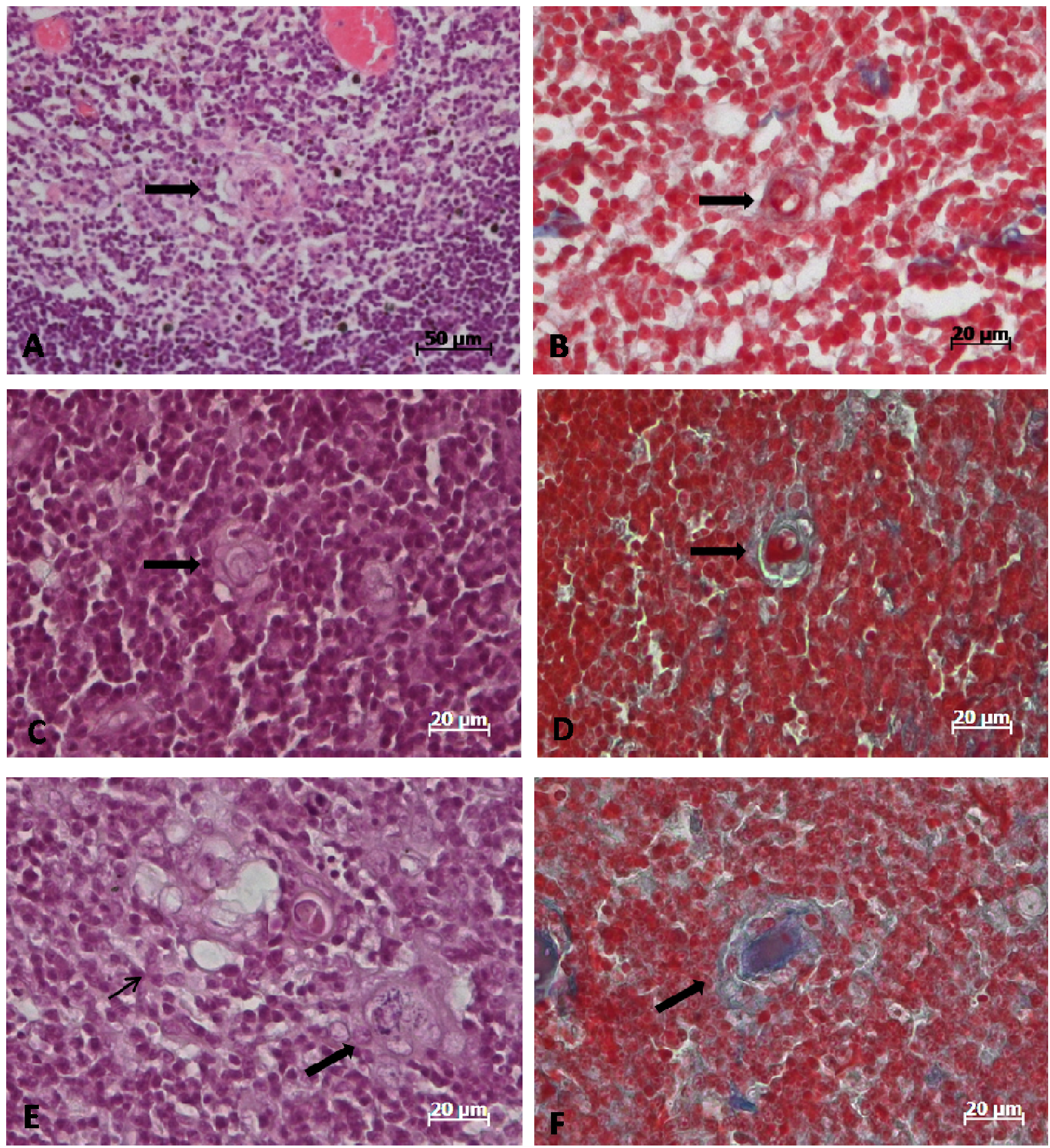

Figura 33 - Fotomicrografia da MT evidenciando-se corpúsculos tímicos nos animais N (A,B); D (C,D) e R (E,F). Verificar a presença de corpúsculo em formação chamado "juvenil" (A, animal N), do tipo "imaturo" (B e C, animal N e D respectivamente); corpúsculo "maduro" (D e $\mathbf{F}$, animal $D$ e $R$ respectivamente), e o corpúsculo do tipo envelhecido ( $E$, animal $R$ ) com conteúdo em aparente degeneração (seta espessa) e dilatação citoplasmática, conferindo a ele uma forma irregular (seta delgada). (A,C e E - H.E.; B,D e F - Tricomio de Masson). 

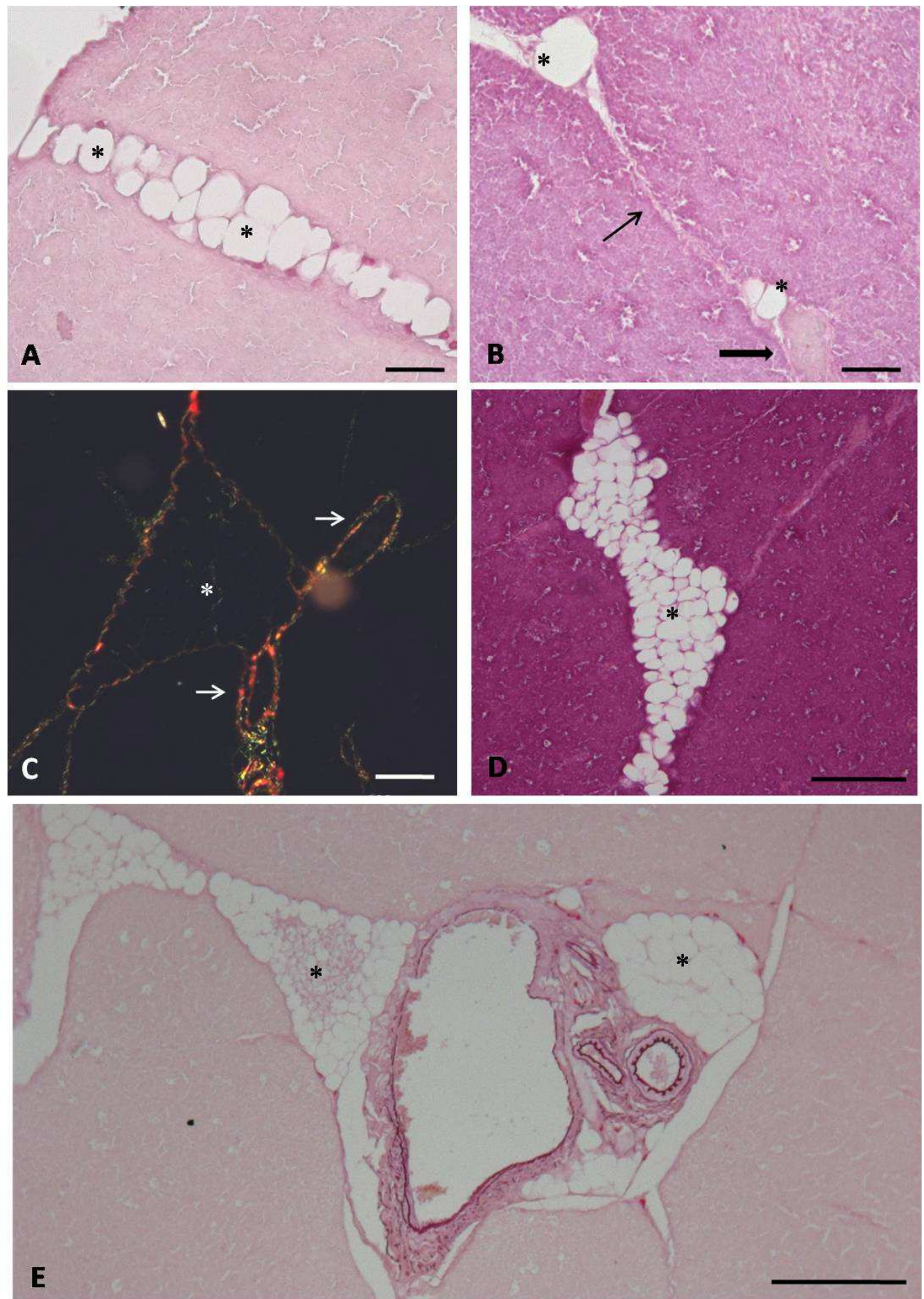

Figura 34 - Fotomicrografia de cortes histológicos do timo de ratos do grupo $D(A, B), R(C, D)$ e $N$ (E). A - Vacúolos interlobulares $(*)$ bem próximos da cápsula tímica; $\mathbf{B}$ - Septo interlobular (seta delgada) com vacúolos interlobulares $(*)$ próximo a vasos interlobulares (seta espessa). C - Vacúolos interlobulares (*) próximo aos vasos interlobulares (setas delgadas), por entre os septos. Observar que os vasos e o septo revelam predominância de colágeno tipo I enquanto que por entre os vacúolos, há uma discreta deposição de colágeno tipo III. D - Vacúolos interlobulares com organizados como um "cacho de uva". E - (A e E- Weigert contra-corado com Van Giensen; B e D - H.E. e C - Picro-sirius sob luz polarizada). (A, B $50 \mu \mathrm{m} ; \mathbf{C}-100 \mu \mathrm{m}, \mathrm{D}, \mathbf{E}-200 \mu \mathrm{m})$. 


\subsection{Aspectos Quantitativos}

Relativamente aos aspectos morfométricos, foram avaliados os seguintes parâmetros: porcentagens de córtex (CT), medula (MT) e tecidos não-linfóides (TNL). Os dados obtidos estão descritos na tabela 4.

Tabela 4 - Média ( \pm IC) da avaliação morfométrica da constituição dos lóbulos tímicos nos diferentes grupos de animais (N, D e R).

\begin{tabular}{lccc}
\hline Análise & Nutridos & Desnutridos & Renutridos \\
\hline & & & \\
\%Córtex tímico & $71,83 \pm 0,7$ & $68,46 \pm 1,8^{*}$ & $71,29 \pm 1$ \\
\%Medula tímica & $20,20 \pm 0,8^{*}$ & $23,25 \pm 1,3$ & $22,9 \pm 0,8$ \\
\%Tecido não-linfóide & $7,97 \pm 0,7$ & $8,29 \pm 1,2$ & $5,71 \pm 0,5^{*}$ \\
& & & ANOVA* $^{*}<0,05$
\end{tabular}

Quando se avaliou o CT, a sua porcentagem de área ocupada no plano de corte não exibiu diferenças estatísticas entre os animais dos grupos $N$ e $R$, tendo sido verificada uma porcentagem ligeiramente menor, porém, estatisticamente significante nos animais do grupo D. A região da MT ocupou uma porcentagem equivalente no plano de corte nos animais $\mathrm{D}$ e $\mathrm{R}$, ambas predominando sobre aquela observada para os animais $\mathrm{N}$. Entre os grupos, o timo dos animais do grupo $\mathrm{R}$ foi o que exibiu a menor porcentagem de área de TNL ocupada no plano de corte; para esse parâmetro, não foram verificadas diferenças significativas entre os grupos de animais $\mathrm{N}$ e D (Figuras 35, 36 e 37). 


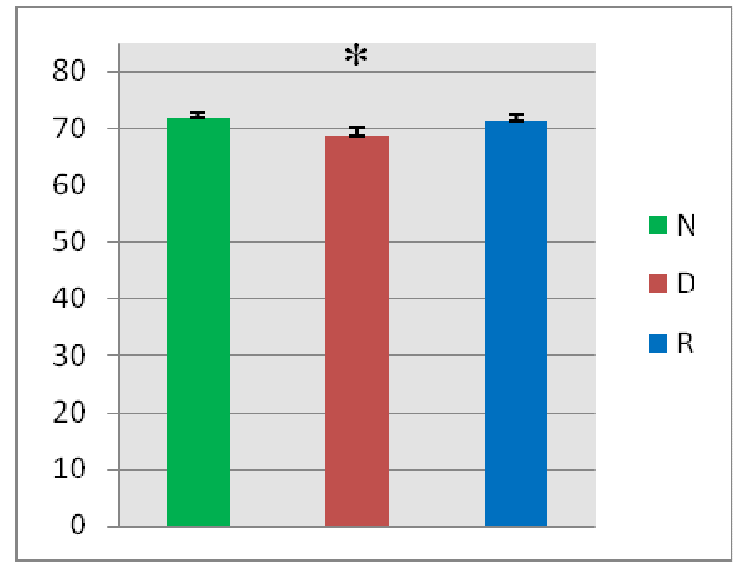

Figura 35 - Gráfico da porcentagem de córtex tímico na maior área de secção transversa $(\% \pm I C)$. $p<0,05 *$.

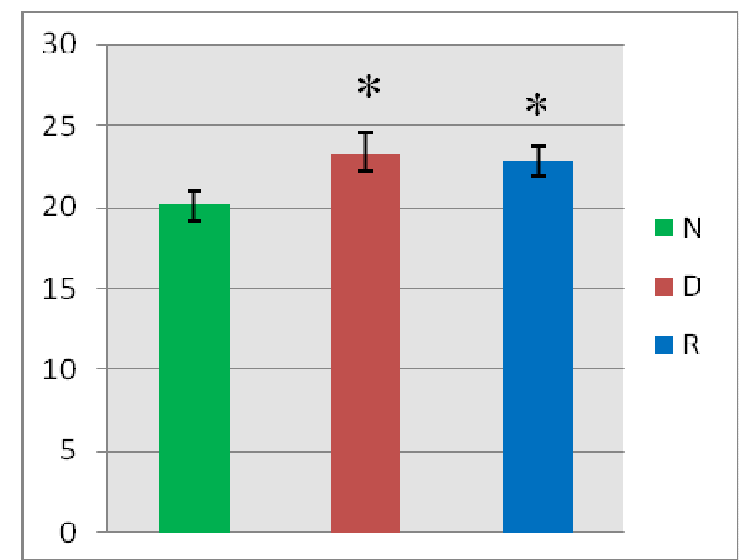

Figura 36 - Gráfico representando a porcentagem de medula tímica na maior área de secção transversa $(\% \pm I C) . p<0,05 *$.

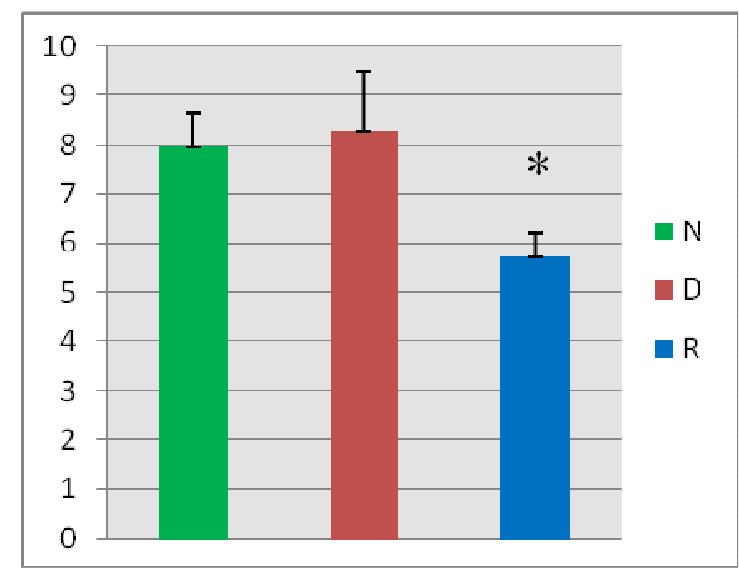

Figura 37 - Gráfico da porcentagem de tecido não-linfóide na maior área de secção transversa $(\% \pm I C)$. $\mathrm{p}<0,05^{*}$. 
Os dados obtidos com a avaliação estereológica sobre a densidade de vasos centrolobulares (DV) e respectivo coeficiente estereológico (CE) presentes na MT de todos os grupos (N, D e R) são verificados na tabela 5.

Tabela 5 - Estereologia da densidade de vasos centrolobulares na MT (média \pm DP).

\begin{tabular}{lccc}
\hline Análise & Nutridos & Desnutridos & Renutridos \\
\hline Densidade de vasos & $36,32 \pm 3,39$ & $11,48 \pm 2,0^{*}$ & $31,32 \pm 6,79$ \\
CE da DV(\%) & 4,18 & 7,8 & 9,7 \\
& & & ANOVA* $\mathrm{P}<0,05$ \\
\hline
\end{tabular}

A densidade de vasos centrolobulares foi maior na MT do timo dos animais dos grupos $\mathrm{N}$ e R, estatisticamente semelhantes entre si; no timo dos animais do grupo $\mathrm{D}$, ocorreu a menor densidade (Figura 38).

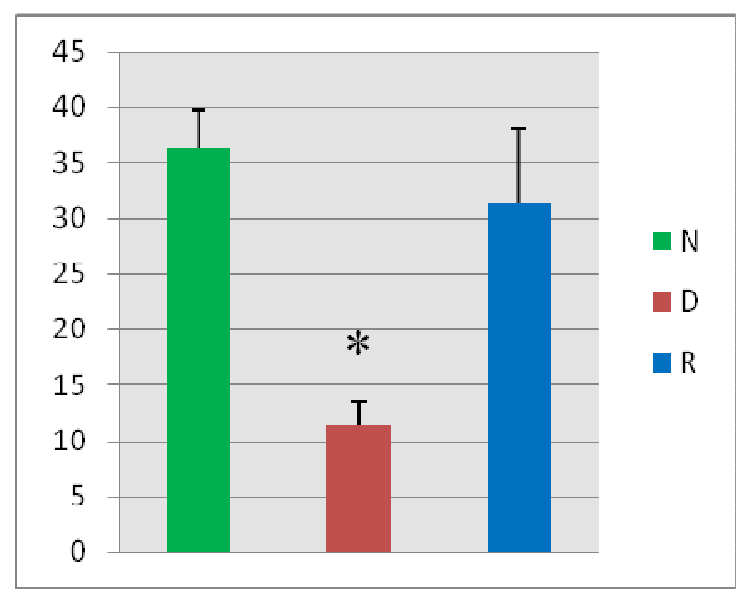

Figura 38 - Gráfico da densidade de vasos na maior área de secção transversa (média $\pm D P$ ). $p<0,05 *$. 
Aqui segue a tabela geral de resultados do experimento.

Tabela 6 - Principais resultados experimentais.

\begin{tabular}{lcccl}
\hline Parâmetros & Nutridos & Desnutridos & Renutridos & Resultados \\
\hline Peso Corporal (g) & $289,7 \pm 13,7$ & $58,6 \pm 18,6$ & $207,9 \pm 17,0$ & $\mathrm{DD}<\mathrm{RN}<\mathrm{NN}^{*}$ \\
Peso tímico animais (g) & $0,74 \pm 0,18$ & $0,16 \pm 0,04$ & $0,85 \pm 0,10$ & $\mathrm{DD}<\mathrm{RN}=\mathrm{NN}^{*}$ \\
\%Peso Tímico/Peso Corporal & $0,26 \pm 0,05$ & $0,26 \pm 0,06$ & $0,40 \pm 0,05$ & $\mathrm{RN}>\mathrm{DD}=\mathrm{NN}^{*}$ \\
Ingestão ração (g) & $15,5 \pm 0,7$ & $7,5 \pm 1,0$ & $13,1 \pm 1,3$ & $\mathrm{DD}<\mathrm{RN}<\mathrm{DD}^{*}$ \\
Ingestão de água (ml) & $25,9 \pm 2,1$ & $11,4 \pm 2,4$ & $20,8 \pm 4,7$ & $\mathrm{DD}<\mathrm{RN}=\mathrm{NN}^{*}$ \\
Eliminação urina (ml) & $15,9 \pm 2,4$ & $5,9 \pm 1,6$ & $12,5 \pm 3,1$ & $\mathrm{DD}<\mathrm{RN}=\mathrm{NN}^{*}$ \\
Eliminação Fezes (g) & $1,95 \pm 0,16$ & $0,98 \pm 0,26$ & $1,63 \pm 0,31$ & $\mathrm{DD}<\mathrm{RN}=\mathrm{NN}^{*}$ \\
\%Ingestão/peso corporal & $10 \pm 0,2$ & $21 \pm 4$ & $14 \pm 1$ & $\mathrm{DD}>\mathrm{RN}=\mathrm{NN}^{*}$ \\
\%Fezes/ingestão & $12 \pm 0,8$ & $14 \pm 4$ & $11 \pm 1$ & $\mathrm{DD}=\mathrm{RN}=\mathrm{NN}^{*}$ \\
Água/peso corporal (ml/g) & $0,16 \pm 0,01$ & $0,29 \pm 0,04$ & $0,21 \pm 0,04$ & $\mathrm{DD}>\mathrm{RN}=\mathrm{NN}^{*}$ \\
\%Urina/água consumida & $60,0 \pm 3,4$ & $52,5 \pm 3,5$ & $59,9 \pm 3,9$ & $\mathrm{DD}<\mathrm{RN}=\mathrm{NN}^{*}$ \\
\%Córtex tímico & $71,83 \pm 0,8$ & $68,46 \pm 2,06$ & $71,29 \pm 1,1$ & $\mathrm{DD}<\mathrm{RN}=\mathrm{NN}^{*}$ \\
\%Medula tímica & $20,20 \pm 1$ & $23,25 \pm 1,49$ & $22,9 \pm 0,9$ & $\mathrm{DD}=\mathrm{RN}>\mathrm{NN}^{*}$ \\
\%Tecido não-linfóide & $7,97 \pm 0,8$ & $8,29 \pm 1,3$ & $5,71 \pm 0,64$ & $\mathrm{RN}<\mathrm{DD}=\mathrm{NN}^{*}$ \\
Densidade de vasos & $36,32 \pm 3,39$ & $11,48 \pm 2,0$ & $31,32 \pm 6,79$ & $\mathrm{DD}<\mathrm{RN}=\mathrm{NN}^{*}$
\end{tabular}


5 DISCUSSÃO 


\subsection{Considerações metabólicas}

Já é sabido que a desnutrição protéica ou protéico-calórica afeta os diferentes órgãos e sistemas seja por comprometimento direto (na celularidade e na função) ou indireto (crescimento e desenvolvimento do organismo em geral), tanto em humanos quanto em modelos experimentais bem controlados (BEDI, 1991; BRANDÃO et al., 2003; CHANDRA, 1991; GOMES et al., 2006; MONTE, 2000; BOLDRINI, 2003).

Apesar destas informações, a compreensão do metabolismo dos animais submetidos à desnutrição elucida muitos comentários acerca desta complexa síndrome, ajudando cientistas e profissionais da saúde a terem dados confiáveis sobre o comprometimento evolutivo, morfofuncional e, inclusive, da recuperação da doença, principalmente através da pesquisa básica (PICHARD, 1997).

Portanto, a utilização de um modelo experimental submetido à desnutrição protéica severa é apropriada por ser o principal tipo de desnutrição em países em desenvolvimento, dada a gama de alimentos ricos em carboidratos (MONTE, 2000; MONTEIRO, 1995); além disso, em se tratando da proteína caseína, o organismo padece com a perda de aminoácidos estruturais indispensáveis (SLOBODIANIK et al., 1989).

Diversos autores têm trabalhado com protocolos experimentais semelhantes ao aplicado nesta pesquisa; porém, utilizando animais de 42 dias (AKAMATSU, 2006; BAUTZ, 2006; BINOTTI, 2003; BOLDRINI, 2003; BRANDÃO et al., 2003; CASTELUCCI et al., 2002; GOMES et al., 2006; MIRANDA, 2006; OLIVEIRA, 2006). Como não se tem referências nesses estudos sobre um acompanhamento até o período aqui avaliado (60 dias) e nem monitoramento metabólico, utilizou-se na presente pesquisa este 
acompanhamento especial, que proporcionou a coleta de dados precisos acerca do metabolismo dos animais de experimentação.

O baixo peso e o retardo do crescimento são os primeiros dados informados quando se promove qualquer tipo de desnutrição (CHANDRA, 1991; MUGERWA, 1971; NUNES, 2002; ROMANI; LIRA, 2004; WATERLOW, 1997; WHO, 1962), o que é confirmado neste modelo experimental, onde os animais desnutridos demonstraram o menor peso corporal, além da menor ingestão de alimento e água, e menor excreção de urina e fezes.

Embora o peso tenha aumentado nos animais do grupo $R$, verificou-se que esse aumento não foi suficiente para alcançar aquele dos animais do grupo $\mathrm{N}$; nem visualmente o comprimento corporal daqueles, se aproximou dos destes, mesmo com o longo período de mudança da dieta aqui empregado, ou seja, 39 dias. Dados similares foram demonstrados por Boldrini (2003) em ratos wistar, e em humanos, na revisão de Monte (2000). Estas observações têm sido atribuídas a alterações da proliferação celular de precursores da medula óssea, que vão agir em resposta a estímulos de crescimento, gerando um prejuízo no desenvolvimento, justamente no período em que o animal mais precisa de aporte protéico (BORSATTO, 1999).

Por outro lado, confirmou-se que a desnutrição baseada na oferta de alimento hipoprotéico levou a uma discrepante disfunção metabólica, revelada pela busca incessante de alimento a fim de satisfazer esta carência protéica, uma vez que a porcentagem de Ingestão/peso corporal foi em média $90 \%$ maior do que a obtida para os animais dos grupos $\mathrm{N}$ e R. Este desequilíbrio metabólico desencadeia uma liberação maciça de corticosteróides endógenos através da ativação do eixo hipotálamohipofisário-adrenal. Segundo Domínguez-Gerpe e Rey-Méndez (2000) e Savino e 
Dardenne (2000) a seqüência se origina a partir de um estímulo do hipotálamo sobre a adenohipófise, resultando na liberação de hormônio adrenocorticotrófico que, no córtex adrenal irá liberar corticóides; estes, em linhas gerais, estimularam a utilização de outras "ferramentas metabólicas", como a lipólise e proteólise, na tentativa de resguardar o organismo.

Para complementar este mecanismo, dois hormônios devem ser considerados: a leptina e o hormônio do crescimento. A leptina é produzida e liberada diretamente proporcional à massa de tecido adiposo do organismo, sinalizando ao hipotálamo a quantidade de energia armazenada, assim como a regulação da ingestão de alimento e a termogênese (SAVINO et al., 2007). O que ocorre neste protocolo experimental de desnutrição protéica é que, como descrito por Pimstone et al. (1968) este tipo de restrição causa aumento dos níveis séricos do hormônio do crescimento, realizando desta maneira lipólise, fornecendo a manutenção do corpo junto com os corticóides por meio dos ácidos graxos. Sendo assim, a secreção de leptina diminui no tecido adiposo, diminuindo o processo de retroalimentação de ingestão de alimento no hipotálamo, fazendo com que ocorra ingestão de alimento em excesso pelo animal, sem saciá-lo.

Curiosamente todos os grupos apresentaram a mesma razão entre eliminação de Fezes/ingestão, evidenciando o não comprometimento funcional do trato gastrointestinal assim como das características morfoquantitativas do plexo mientérico de ratos desnutridos, como descrito por Brandão et al. (2003), Castelucci et al. (2002), Gomes et al. (2006) e Gréggio (2001). Sendo assim, como os animais do grupo D sofrem privação protéica, acredita-se que seu sistema digestório não exiba alterações severas e, sim, procure formas de adaptação que permitam resistir a esta injúria, com o propósito de absorver o máximo possível de nutrientes. 
Da mesma forma, o desarranjo metabólico e conseqüente liberação excessiva de corticosteróides endógenos levam ao aumento da proporção de Água/peso corporal dos animais $\mathrm{D}$ (na ordem de $81 \%$ maior do que o verificado para os grupos $\mathrm{N}$ e $\mathrm{R}$ ), ao passo que a eliminação de Urina/água consumida foi $12 \%$ menor, comparativamente aos outros dois grupos, o que permite inferir que esses animais consomem e utilizam mais água em suas necessidades metabólicas ou a retêm nos tecidos, provavelmente pelo baixo nível de proteínas plasmáticas.

Salvo o peso corporal final e a média final de ingestão de ração, todos os outros parâmetros analisados (ingestão de água, excreção de urina e fezes, Ingestão/peso corporal, Água/peso corporal, Fezes/ingestão e Urinalágua consumida) nos animais renutridos são pareados aos dos animais nutridos. Some-se a isso, o início, a partir do $17^{\circ}$ dia, da mudança no comportamento metabólico dos animais $R$, mesmo antes da intervenção nutricional alcançar a metade do período de monitoramento.

Todas estas evidencias relativas ao restabelecimento nutricional dos animais do grupo $\mathrm{R}$ são ratificadas, sobretudo quando se observa que eles apresentaram um crescimento em média de $93,5 \%$ e, $141 \%$ maior que os animais $\mathrm{N}$ e D respectivamente, quando analisado o desenvolvimento do peso corporal do primeiro em relação ao último dia de monitoramento metabólico.

Por todos estes dados até aqui mencionados, verifica-se que é de maneira bastante ágil que os animais renutridos retomam suas atividades metabólicas normais, isto é, comportam-se como os animais nutridos. Acredita-se serem esses dados importantes, pois na literatura não foram encontrados resultados conclusivos, limitandose a apenas comentários, sobre o sucesso da intervenção nutricional no metabolismo, quer seja de animais ou humanos desnutridos. 


\subsection{Considerações morfológicas}

Com finalidade de estudar os efeitos da desnutrição no tecido linfóide, e conseqüentemente no sistema imunológico, os pesquisadores têm utilizado diferentes protocolos experimentais que induzem esta condição (CHANDRA, 1992; LAMONT; GORDON; FERGUSON, 1988). Sendo assim, a presente pesquisa se concentrou no período pré e pós-natal por se tratarem dos principais momentos de maturação, desenvolvimento e constituição de tecidos e órgãos, principalmente o timo (SLOBODIANIK et al., 1989; WATERLOW, 1997), tão fundamental para integridade do sistema imune.

Desta forma, a preocupação em avaliar as diferentes variáveis relativas ao timo, iniciou-se com a determinação da sua massa, indicativo importante da condição de um tecido linfóide. Assim, notou-se que os animais do grupo D sofreram uma atrofia tímica impressionante, ou seja, a média de peso foi somente $20 \%$ daquela verificada para os animais do grupo N, fato já observado por Mittal, Woodward e Chandra (1988) em ratos. Estatisticamente, verificou-se que a renutrição foi eficaz no retorno da massa tímica, uma vez que o timo dos animais do grupo $\mathrm{R}$ não exibiram peso diferente daquele encontrado para o grupo N. Esses resultados são compatíveis com as afirmações de Barone, O`Brien e Stevenson (1993), muito embora estes autores não tenham demonstrado dados comprobatórios com a intervenção nutricional.

Não obstante, a razão Peso tímico/Peso corporal se manteve nos grupos $\mathrm{N}$ e $\mathrm{D}$, ao contrário do relatado por Weindruch e Suffin (1980), que utilizaram um modelo experimental de desnutrição energética. Uma característica importante aqui observada para esta relação, e que não foi avaliada nos trabalhos consultados sobre os efeitos da 
desnutrição no timo, foi aquela referente aos animais do grupo R. Nestes, a maior porcentagem (54\%) indicando um peso tímico ligeiramente maior do que o do animal $\mathrm{N}$, demonstrou uma evolução do parênquima do órgão quando retornada a alimentação normoprotéica que, porém, deve ser interpretada como um retardo na retomada do peso corporal intuindo, assim, um timo adequado para idade; porém, com uma massa corporal menor.

Se considerado o atraso no desenvolvimento antropométrico dos animais do grupo $\mathrm{R}$, este repercutiu de tal forma na morfologia macroscópica do timo, fazendo com que se desenvolvesse mais no sentido ântero-posterior, e não no sentido látero-lateral, como é normal de observar. Provavelmente, isto se deva ao crescimento restrito do tórax destes animais, determinando uma restrição da expansão da glândula nesta direção, apesar da planimetria de corte, peso tímico e o comprimento longitudinal não mostrarem nenhuma diferença em relação aos animais do grupo N. Vale aqui salientar que tais observações morfológicas não foram referidas na literatura à qual se teve acesso.

A superfície dos timos dos ratos $\mathrm{N}$ exibiu discretas, porém, inúmeras reentrâncias da cápsula que reveste o órgão, conferindo-lhe um aspecto crenado, invaginando o CT, mas não alcançando a MT. Esta particularidade, referida pelos autores apenas como um meio de tráfego para os vasos foi também aqui notada, porém, sem a preocupação de se determinar qual tipo de vaso predomina nessas reentrâncias, o que foi determinado por Kato (1997) utilizando técnica adequada para visualização de vasos em microscopia eletrônica de varredura. Este autor descreveu que a maior parte dos vasos localizados na cápsula, são linfáticos, o que abre uma perspectiva para estudos ulteriores comparativos em animais desnutridos e renutridos. 
Como nos animais dos grupos $D$ e $R$, pouquíssimas dessas reentrâncias oriundas da cápsula foram observadas, pode-se inferir que a sua ausência interfira no suporte e sustentação do parênquima, pois se entende que o apoio dos lóbulos ocorra através da ancoragem na cápsula tímica. De fato, essa afirmação pode ser correlacionada com os achados referentes à estrutura da cápsula tímica, avaliada sob luz polarizada. Nesse estudo, ficou evidente que, no timo dos animais do grupo D a cápsula e os septos, embora constituídos por fibras colágenas predominantemente do tipo I eram delgados; nos animais dos grupos $\mathrm{N}$ e $\mathrm{R}$ além da cápsula e septo mais espessos e formados por fibras colágenas do tipo I, uma grande quantidade de fibras do tipo III foi detectada.

Todavia, quando se analisou a quantidade de tecido conjuntivo periglandular, isto é, o tecido conjuntivo relacionado às estruturas ao redor do timo, verificou-se que o mesmo, por se apresentar em maior quantidade nos animais do grupo $D$, dificultava o acesso à glândula, o que é compatível com as descrições de Mugerwa (1971), que observou um aumento de tecido conjuntivo ao redor do timo de crianças severamente desnutridas.

Dados sobre a atrofia tímica têm sido descritos a partir da década de 1970 (MUGERWA, 1971; OLUSI; McFARLANE, 1976) através de abordagens diferentes sobre cada aspecto encontrado neste órgão. Assim, pesquisadores como Chandra (1992), Leite de Moraes et al. (1991), Mittal e Woodward (1985), Prentice (1999), e Weindruch e Suffin (1980) utilizaram-se de observações qualitativas ou, apenas, apresentaram resultados baseados em medidas ponderais que, em suma, 
demonstravam uma análise geral da situação do órgão, no que diz respeito à sua morfologia.

No entanto, para sancionar estas informações os dados quantitativos somados aos qualitativos elucidam esta discussão. Deste modo, é asseverado que os animais do grupo D sofrem atrofia, por revelarem lóbulos em quantidade e dimensões menores, com discreto limite córtico-medular, além de exibir uma menor porcentagem de CT por plano de corte, referindo também um menor índice córtex:medula. Ainda que Mittal, Woodward e Chandra (1988) discorram sobre a ocorrência de atrofia, porém, sem haver diferença no índice córtex:medula entre os animais $\mathrm{N}$ e D (ou seja, em ambos os grupos, este se manteve na proporção de $2: 1$ ), nos resultados aqui apresentados tal fato não se confirmou, pois o mesmo ocorreu na proporção de 2,9:1 nos animais do grupo $\mathrm{D}$ e de 3,6:1 nos animais do grupo $\mathrm{N}$. Estatisticamente, os grupos $\mathrm{N}$ e $\mathrm{D}$ foram diferentes quanto a esse aspecto; todavia, quando se comparou o grupo $\mathrm{N}$ com o grupo $R$, estes não diferiram entre si, pois essa relação se estabeleceu na ordem de $3,1: 1$ nos animais renutridos.

A depleção de timócitos no córtex tímico oriundo da desnutrição ocorre por apoptose destas células, cujo mecanismo ascende de várias naturezas (SAVINO; SANTA-ROSA, 1982), fato estudado intensamente por Barone, O`Brien e Stevenson (1993). Portanto, através da disfunção metabólica gerada pela desnutrição, e a estimulação do eixo hipotálamo-hipófise-adrenal, os altos níveis de corticosteróides endógenos circulantes levam, como já descrito, à apoptose dos timócitos, de forma direta. Estas mesmas substâncias, além de determinarem a secreção de matriz extracelular anormal nas células reticulares epiteliais, concorrem para a diminuição do seu número; assim, elas não agiriam maturando os linfócitos na região cortical, levando 
à apoptose dos timócitos imaturos (BARONE; O`BRIEN; STEVENSON, 1993; DOUROV, 1986; LYRA et al., 1993; SAVINO; DARDENE, 2000).

Essas observações podem ser comprovadas no caso de modelos experimentais usando ratos infectados com Trypanosoma cruzi e Schistosoma mansoni, onde se verificou atrofia tímica similar ao que acontece em timo de ratos desnutridos; contudo, após adrenelectomia nestes animais, ocorre retorno qualitativo da morfologia do timo (LEITE DE MORAES et al., 1991; SAVINO et al., 1989, 2006).

Considerando-se as descrições histológicas do timo, onde Elmore (2006) padronizou um critério histopatológico para a detecção de timócitos em processo de apoptose, os dados na presente pesquisa referentes a esse tipo celular encontrado no parênquima do timo de animais do grupo $\mathrm{D}$, permitem concordar com os achados dos autores anteriormente citados. Mormente pelo fato de ter sido detectado na medula desses animais, quantidade excessiva de células em apoptose, que pode aumentar o risco de desenvolvimento de doenças auto-imunes (SELLMEYER et al, 1972).

Relativamente às células reticulares epiteliais, Lyra et al. (1993), afirmaram que a depleção direta de timócitos por estas células acontece através da secreção de proteínas colágenas e não-colágenas no retículo tímico, bem como a liberação de fibronectina, que agirá diminuindo a mitose de linfócitos no tecido linfóide periférico. Conseqüentemente à diminuição do número de células reticulares epiteliais na desnutrição (MITTAL; WOODWARD; CHANDRA, 1988), ocorre nas células remanescentes, uma diminuição na quantidade de vacúolos citoplasmáticos em seu interior (MITTAL; WOODWARD, 1985) levando a uma redução do nível sérico de timulina (CHANDRA, 1989) que, por sua vez, agiria na proliferação de linfócitos no timo e nas áreas timo-dependentes (GOLDSTEIN; SLATER; WHITE, 1966). 
De maneira funcional, a atrofia que acomete o CT dos animais do grupo D é acompanhada pela diminuição da DV na MT, ocorrendo um comprometimento do egresso de timócitos para a corrente sanguínea, mesmo que se suceda apenas para linfócitos maduros; o que não sobrevém nos animais $R$. Sendo assim, a imunidade mediada por células estará comprometida de tal forma, que agentes oportunistas conseguiriam agir contra o organismo ou, por egresso de células alteradas, a probabilidade de ocorrência de doenças auto-imunes se tornaria maior (SELLMEYER et al., 1972).

Como comprovação da evolução morfológica nos animais do grupo $R$, como já mencionado, os mesmos revelaram um parênquima compatível com a expansão de seus lóbulos, pois exibiram a menor porcentagem de TNL no plano de corte. Desta maneira, pode-se afirmar que, rapidamente, o tecido linfo-hematopoiético (especialmente o timo), altera-se muito com esta injúria, o que foi bem caracterizado por autores como Slobodianik et al. (1989), Barone; O'Brien; Stevenson (1993). Entretanto, de maneira tão rápida quanto, sua morfologia retorna, espelhando também, o retorno das atividades imunológicas, uma vez que não se detectou, quantitativa ou qualitativamente, dados capazes de indicar a manutenção da atrofia tímica pósrecuperação protéica. Tais descrições corroboram com Olusi e McFarlane (1976) ao especularem sobre o retorno da morfologia do órgão após a intervenção nutricional.

No entanto, a porcentagem de MT nos animais do grupo $R$, semelhante à verificada para os animais do grupo $D$, pode ser explicada pelo fato dos animais renutridos revelaram a menor porcentagem de TNL inferindo, como já proferido, na ascendente recuperação do parênquima tímico após o período de desnutrição, compatível com evolução dos lóbulos tímicos. 
Relativamente aos corpúsculos tímicos, o que se observou no grupo controle $(\mathrm{N})$ foram formações corpusculares de vários tipos, variando em número por MT. Assim como os achados de Cardellini, Panzica e Candiollo (1980) e de Liberti (1984), que verificaram uma porção maior de corpúsculos do tipo císticos, 4 tipos foram observados em todos os grupos experimentais de acordo com as descrições de Raica et al. (2006).

Muito embora tenha se achado pouco destas estruturas nos animais do grupo D, os corpúsculos dos tipos "maduro" e "envelhecido" eram os mais constantes nestes, e nos animais do grupo $R$, ao contrário do verificado para o grupo $N$, que exibiu quantidade razoável de todos os tipos. Além disso, muitos corpúsculos de forma irregular e dilatados, contendo material necrótico em seu interior, foram notados nos animais renutridos, e em pouca quantidade nos animais do grupo D. Esses dados estão de acordo com a pesquisa de Revillard e Cozon (1990), que notaram a ocorrência de corpúsculos císticos dilatados e degenerados em animais submetidos à desnutrição protéico-calórica e atribuído por Hale e Markert (2004), como uma influência do nível de corticosteróide circulante atuando na diferenciação e formação dos corpúsculos tímicos. Ainda pode-se admitir que a diminuição do número de corpúsculos nos animais do grupo D, seja decorrente da alteração sofrida pelo nível de corticóides circulantes, que segundo Mugerwa (1971) e Lyra e al. (1993) determina uma diminuição no número das células reticulares epiteliais e conseqüente diminuição no número corpúsculos.

Apesar de fornecerem vasto material acerca da estrutura dos corpúsculos tímicos, os vários estudos não demonstram resultados concludentes, sobre a sua função na morfologia tímica. Mesmo já se sabendo que existe uma grande taxa de mitose de linfócitos no córtex tímico; que a maturação destes ocorre pelas células reticulares epiteliais; que sua seleção negativa acontece no parênquima, e ainda sim 
pouca quantidade destes adentram a corrente sanguínea para prover imunidade (SAVINO, 2006; SAVINO; SANTA-ROSA, 1982), é válido dizer que, provavelmente, os corpúsculos tímicos estejam também, diretamente envolvidos na seleção negativa de timócitos.

Todavia, pelo que se verificou na presente pesquisa, é possível compartilhar com a idéia de Farr, Dooley e Erickson (2002), ao admitirem que estas estruturas serviriam de "cemitérios" de linfócitos que, na verdade, foram selecionados negativamente e fagocitados, revelando, como nos casos de corpúsculos envelhecidos, material necrótico e até mesmo calcificado em sua parte central (RAICA et al., 2005).

Fato digno de nota refere-se aos estudos de Hale e Markert (2004) que, avaliando timos de crianças portadoras de imunodeficiência verificaram que as mesmas carecem de timopoiese, interpretado como um retardo na maturação de células T; nestes casos, não detectaram corpúsculos tímicos degenerados e com calcificação central. Essas observações não podem ser relacionadas aos efeitos da desnutrição sobre o parênquima tímico dos animais do grupo $D$ do presente estudo, uma vez que, como já mencionado, todos os tipos de corpúsculos foram detectados nesse grupo.

Finalizando, do ponto de vista evolutivo ou degenerativo, mais uma semelhança foi encontrada entre os animais dos grupos D e R, ou seja, a presença de vacúolos em grande número nos septos interlobulares e/ou próximo aos vasos interlobulares, comparativamente aos animais do grupo N. Sugestivos de espaços que contêm tecido adiposo indicam involução do órgão, sendo encontrados em timos de animais idosos (MITTAL; WOODWARD, 1984) e de crianças severamente desnutridas (MUGERWA, 1971). 
6 CONCLUSÃO 
Frente à condição de desnutrição, o organismo pode sofrer adaptações ou mesmo alterações irreparáveis dependendo do momento da vida. Conforme o proposto na pesquisa, somada à metodologia utilizada, os resultados proporcionaram fundamentadas proposições permitindo concluir que:

1. A média do peso corporal final e da ingestão de alimento final variou, sendo maior para o grupo $\mathrm{N}$, menor para o grupo $\mathrm{D}$, enquanto se apresentava com valor médio para o grupo $R$.

2. Proporcionalmente, a desnutrição promoveu a maior razão Ingestão/peso corporal, Água/peso corporal, e menor razão Urina/água consumida.

3. Não houve diferença entre os grupos experimentais quanto à razão Fezes/ingestão.

4. Na maioria dos parâmetros analisados os animais do grupo $R$ se comportam metabolicamente igual aos do grupo $\mathrm{N}$, sobretudo após o $17^{\circ}$ dia de monitoramento.

5. A razão Peso tímico/Peso corporal foi maior nos animais do grupo $\mathrm{R}$ por apresentarem menor peso corporal. 
6. A cápsula tímica apresentou invaginações que conferiram um aspecto crenado à superfície de corte do timo nos animais do grupo $\mathrm{N}$, não sendo observado o mesmo para os animais dos grupos $\mathrm{D}$ e R.

7. A desnutrição afetou os componentes elásticos e fibrosos do arcabouço de sustentação do parênquima tímico.

8. A atrofia tímica que ocorreu nos animais do grupo $D$ foi marcada pelo exuberante número de timócitos em apoptose e diminuição da porcentagem de córtex tímico.

9. A proporção córtex:medula foi menor nos animais D, não ocorrendo inferência estatística entre os animais $\mathrm{N}$ e $\mathrm{R}$.

10. A densidade de vasos na medula tímica foi menor para os animais do grupo $\mathrm{D}$, e não diferenciou entre os grupos $\mathrm{N}$ e $\mathrm{R}$.

11. O aumento da porcentagem de medula tímica no grupo $D$ foi ocasionado pela atrofia cortical, e manutenção do TNL, comparativamente ao grupo N. Os animais do grupo $\mathrm{R}$ apresentaram a porcentagem de medula tímica similar as dos animais do grupo D, porém, explicado por apresentarem menor porcentagem de TNL. 
12. Nos animais R e D predominaram os corpúsculos tímicos "maduro" e "imaturo"; os animais D revelaram poucos corpúsculos tímicos

13. A presença de vacúolos interlobulares no grupo $R$ como no grupo $D$, demonstrou involução mais avançada da glândula, visto que o grupo $\mathrm{N}$ exibia pouca destas estruturas.

14. Em linhas gerais, a intervenção nutricional foi efetiva no retorno da morfologia do timo. 


\section{REFERÊNCIAS}

AKAMATSU, F. E. Características Estruturais, Ultra-estruturais e Morfométricas do Plexo Subepicárdico de Ratos Submetidos à Desnutrição Protéica Pré e Pós-natal e a Renutrição Pós-natal. 157 f. Tese (Doutorado em Ciências Morfofuncionais) Instituto de Ciências Biomédicas, Universidade de São Paulo, São Paulo, 2006.

BACH, J.F.; DARDENNE, M.; PLÉAU, J.M.; BACH, M.A. Isolation, Biochemical characteristics and biological activity of a circulating thymic hormone in the mouse and in the human. Ann. New York Acad. Sci., v. 249, p. 186-210, 1975.

BARONE, K.S.; O'BRIEN, P.C.M.; STEVENSON, J. Characterization and Mechanisms of Thymic Atrophy in Protein-Malnourished Mice: Role of Corticosterone. Cell. Immun., v. 148, p.226-223, 1993.

BAUTZ, W. G. Repercussões Morfológicas da Desnutrição Protéica Pré e Pósnatal e da Renutrição Pós-natal no Reparo da Mucosa e do Osso Alveolar da Mandíbula de Ratos após a Extração do Primeiro Molar. 81 f. Dissertação (Mestrado em Ciências Morfofuncionais) - Instituto de Ciências Biomédicas, Universidade de São Paulo, São Paulo, 2006.

BEDI, K..S. Effects of Undernutrition During Early life on Granule Cell Numbers in the rat Dentate Gyrus. J. Comp. Neurol., v. 311, p. 425-433, 1991.

BEHMER, O.A.; DE TOLOSA, E.M.C.; FREITAS NETO, A.G. Manual de Técnicas para Histologia Normal e Patológica. São Paulo: EDART, 1975.

BELL, E.T. The development of the thymus. Am. J. Anat., v. 5, p. 56-60, 1906.

BINOTTI, C.B. Repercussões Morfológicas da Desnutrição Protéica Pré e Pósnatal e da Renutrição Pós-natal sobre o Nervo Alveolar Inferior de Ratos Jovens. 94 f. Tese (Doutorado em Ciências Morfofuncionais) - Instituto de Ciências Biomédicas, Universidade de São Paulo, São Paulo, 2003.

BOLDRINI, S.C. Efeitos da Desnutrição Pré e Pós-natal e da Renutrição Pós-natal sobre o Crescimento Craniofacial de Ratos Wistar: Análise Craniométrica, Morfoquantitativa e Ultra-estrutural. 69 f. Tese (Doutorado em Ciências Morfofuncionais) - Instituto de Ciências Biomédicas, Universidade de São Paulo, São Paulo, 2003.

BORSATTO, E.M. Desnutrição Protéica: avaliação in vitro da capacidade proliferativa de progenitores grânulo-monócitos da medula óssea de camundongos. 83 f.

\footnotetext{
* De acordo com ASSOCIAÇÃO BRASILEIRA DE NORMAS TÉCNICAS (ABNT). NBR 6023: informação e documentação: referências: elaboração. Rio de Janeiro, 2002.
} 
Dissertação (Mestrado em Análises Clínicas) - Faculdade de Ciências Farmacêuticas, Universidade de São Paulo, São Paulo, São Paulo, 1999.

BRANDÃO, M.C.S.; ANGELIS, R.C.; SOUZA, R.R.; FRÓES, L.B; LIBERTI, E.A. Effects of pre- and postnatal protein energy deprivation on the myenteric plexus of the small intestine: a morphometric study in weanling rats. Nutr. Res., v. 75, p. 7-15, 2003.

CARDELLINI, C.; PANZICA, G.; CANDIOLLO, L. Studio strutturale, ultrastrutturale e quantitativo Del corpuscolo di Hassall nel corso dello sviluppo. Arch. Ital. Anat. Embriol., v.85, p.127-147, 1980.

CASTELUCCI, P.; SOUZA, R.R.; ANGELIS, R.C.; FURNESS, J.B.; LIBERTI, E.A. Effects of pre- and postnatal protein deprivation and postnatal refeeding on myenteric neurons of the rat large intestine: a quantitative morphological study. Cell Tissue Res., v. 310 , p. $1-7,2002$

CHANDRA, R.K. Nutritional Regulation of Immunitary and Risk of Illness. Indian J. Pediatr., v. 56, p. 607-611, 1989.

CHANDRA, R.K. Nutrition \& Immunity. Clin. Immun., v. 25, p. 1-10, 1991.

CHANDRA, R.K. Protein-Energy Malnutrition and Immunological Responses. J. Nutr., v. 122, p. 597-600, 1992.

DARDENNE, M.; SAVINO, W.; WADE, S.; KAISERLIAN, D.; LEMONNIER, D. BACH, J. In vivo and in vitro studies of thymulin in marginally zinc-deficient mice. Eur. J. Immunol., v.14, p. 454-458, 1984.

DOUROV, N. Thymic atrophy and immune deficiency in malnutrition. Curr. Top. Pathol., v. 75, p. 127-150, 1986.

DOMÍNGUEZ-GERPE, L.; REY-MÉNDEZ, M. Role of Pre-T Cells and Chemoattractants on Stress-Associated Thymus Involution. Scand. J. Immunol., v.52, p. 470-476, 2000.

DRENCHAHN, D.; UNSICKER, K.; GRIESSER, G.-H.; SCHUMACHER, U.; GROSCHEL-STEWART, U. Different myoisis in myoid and entodermal reticular epithelial cells of the Thymus. Cell Tiss. Res., v. 187, p. 98-103, 1978.

DRENCHAHN, D.; GAUDECKER, B.V.; MULLER-HERMELINK, H.K.; UNSICKER, K. Myosin and actin containing cells in the Human post-natal Thymus. Ultrastructural and immunohistochemical findings in normal Thymus and myasthenia gravis. Virchows Arch. Cell Pathol., v. 32, p. 33-46, 1979.

ELMORE, S.A. Enhanced Histophatology of the Thymus. Toxicol. Pathol., v. 34, n. 5, p. 656-665, 2006. 
FARR, A.G.; DOOLEY, J.L.; ERICKSON, M. Organization of thymic medullary epithelial heterogeneity: implications for mechanisms of epithelial differentiation. Immun. Rev., v. 189, p. 20-27, 2002.

FISHER, L.D.; VAN BELLE, G. Biostatistics. A Methodology for Health Sciences. New York: Wiley, 1993.

GARDNER, E.; GRAY, D.J.; O'RAHILLY, R. Anatomia. Estudo regional do corpo humano. 3. ed. Rio de Janeiro: Guanabara Koogan, 1971.

GOLDSTEIN, A.L.; SLATER, F.D.; WHITE, A. Preparation, assay and partial purification of a thymic lymphoid factor (thymosin). Proc. Nat. Acad. Sci., v. 56, p. 1010-1017, 1966.

GOLDSTEIN, G. The isolation of thymopoetin (thymin). Ann. New York Acad. Sci., v. 249, p. 177-185, 1975.

GOMES, O.A,; CASTELUCCI, P.; de VASCONCELOS FONTES, R.B.; LIBERTI, E.A. Effects of pre- and postnatal protein deprivation and postnatal refeeding on myenteric neurons of the rat small intestine: a quantitative morphological study. Auton. Neurosci., v. 126-127, p. 277-84, 2006.

GRÉGGIO, F.M. Avaliação Histoquímica e Morfométrica dsp Efeitos da Desnutrição Pré e Pós-natal e da Renutrição Pós-natal no Plexo Mientérico do Esôfago de Ratos. 55 f. Dissertação (Mestrado em Anatomia Funcional: Estrutura e Ultra-estrutura) - Instituto de Ciências Biomédicas, Universidade de São Paulo, São Paulo, 2001.

GUNDERSEN, H.J.G.; BENDTSEN, T.F.; KORBO, L.; MARCUSSEN, N.; MOLLER, A.; NIELSEN, K.; NYENGAARD, J.R.; PAKKENBERG, B.; SORENSEN, F.B.; VESTERBY, A.; WEST, M.J. Some new, simple and efficient stereological methods and their use in pathological research and diagnosis. APMIS, v. 151, p. 3-21, 1988.

GUYTON, A.C.; HALL, J.E. Fisiologia Médica. 10. ed. Rio de Janeiro: Guanabara Koogan, 2002.

HALE, L.P.; MARKERT, M.L. Corticosteroids regulate epithelial cell differentiation and Hassall body formation in the human thymus. J. Immun., v. 172, p. 617-624, 2004.

HUANG, Z.L.; FRAKER, P.J. Chronic Consuption of a Moderately low protein Diet does not Alter Hematopoietic Processes in Young Adult Mice. J. Nutr., v. 133, p. 1403-1408, 2003.

JAMBON, B.; ZIEGLER, O.; MAIRE, B.; HUTIN, MF.; PARENT,G.; FALL, M.; BURNEL, D.; DUHEILLE, J. Thymulin (facteur thymique serique) and zinc contents of the thymus glands of malnourished children. Am. J. Clin. Nutr., v. 48, p. 335-342, 1988. 
JUNQUEIRA, L.C.; CARNEIRO, J. Histologia básica. 9. ed. Rio de Janeiro: Guanabara Koogan, 1999.

KATO, S. Thymic Microvascular System. Microsc. Res. Tech., v. 38, p. 287-299, 1997.

LAMONT, A.G.; GORDON, M.; FERGUSON, A. T lymphocyte function in protein deprived mice. Clin. Exp. Immunol., v. 72, p. 113-117, 1988.

LESOURD, B.M.; MAZARI, L. Immune Responses During Recovery from Protein-energy Malnutrition. Clin. Nutr., v. 16, p. 37-46, 1997.

LEITE DE MORAES, M.C.; HONTEBEYRIE-JOSKOWICZ, M.; LEBOULENGER, F.; SAVINO, W.; DARDENNE, M.; LEPAULT, F. Studies on teh Thymus in Chagas disease II. Thymocites Subset Fluctuations in Trypanosoma cruzi-infected mice: Relationship to Stress. Scand. J. Immunol., v. 33, p. 267-275, 1991.

LIBERTI, E.A. Estudo Morfofuncional do timo humano (16-31 semanas V.I.U.). Dissertação de Doutorado apresentado ao Instituto de Ciências Biomédicas. São Paulo, 1984.

LIBERTI, E.A.; VILLA, N.; MELHEM, S.A.M.; MATSON, E.; KÖNIG jr., B. A Morphometrical Study of Human Fetal Thymus. Z. Mikrosk. Anat. Forsch., v.103, p. 309-15, 1989.

LYRA, J.S.P.O.; MADI, K.; MAEDA, C.P.; SAVINO, W. Thymic extracellular matrix in human malnutrition. J. Pathol., v. 171, p. 231-236, 1993.

MANDARIM-DE-LACERDA, C.A. Métodos quantitativos em morfologia. Rio de Janeiro: Ed. UERJ, 1995.

McDADE, T.W.; BECK, M.A.; KUZAWA, C.W.; ADAIR, L.S. Prenatal Undernutrition and Postnatal Growth are Associated with Adolescent Thymic Function. J. Nutr., v. 131, p. 1225-1231, 2001.

MITTAL, A.; WOODWARD. B. Thymic Epithelial Cells of Severely Undernourished Mice: Accumulation of Cholesteryl Esters and Absence of Cytoplasmatic Vacuoles. Proc. Soc. Exp. Biol. Med., v.178, n. 3, p.385-91, 1985.

MITTAL, A.; WOODWARD. B.; CHANDRA, R.K. Involution of thymic epithelium and low serum thymulin bioactivity in weanling mice subjected to severe food intake restriction or severe protein deficiency. Exp. Mol. Pathol., v.48, p. 226-235, 1988.

MIRANDA, C. M. Repercussões Morfológicas da Desnutrição Protéica Pré e PósNatal e da Renutrição Pós-natal sobre a Lâmina Epifisial e a Cartilagem de Ossos 
Longos de Ratos Wistar. Dissertação (Mestrado em Ciências Morfofuncionais) Instituto de Ciências Biomédicas, Universidade de São Paulo, São Paulo, 2006.

MONTE, C.M.G. Desnutrição: um desafio secular à nutrição infantil. J. Ped., v. 76, n. 3, p. 285-297, 2000.

MONTEIRO, C.A. A dimensão da pobreza, da fome e da desnutrição no Brasil. Estudos Avançados, v.9, n. 24, p. 1995-207, 1995.

MONTES, G.S.; JUNQUEIRA, L.C.U. The use of the picrosirius-polariation method for the study of the biopathology of collagen. Mem. Inst. Oswaldo Cruz, v. 86, n. 3, p. 1-11, 1991.

MOORE, K.L.; DALLEY, A.F. Anatomia orientada para a clínica. 3. ed. Rio de Janeiro: Guanabara Koogan, 1994.

MOORE, S.E.; COLE, T.J.; POSKITT, E.M.; SONKO, B.J.; HWITCHEAD, R.G.; McGREGOR, I.A.; PRENTICE, A.M. Season of birth prediets mortality in rural Gambia. Nature, v. 338, p. 434, 1997.

MOURA-CAMPOS, L.C.; SAVINO, W. Morphometrical Analysis of the Thymus from Mice Submited to Low Temperature. Acta Anat., v. 132, p. 9-11, 1988.

MUGERWA, J.W. The Lymphoreticular system in kwashiorkor. J. Pathol., v.105, p.105109, 1971.

NUNES, M.L.; BATISTA, B.B.; MICHELI, F.; BATISTELA, F. Efeitos da Desnutrição precoce e Reabilitação Nutricional em Ratos. J. Pediatria, v. 78, p. 39-44, 2002.

OLIVEIRA, F. Características Histoquímicas das Fibras Musculares do $\mathbf{M}$. Gastrocnêmio de Ratos Wistar Desnutridos submetidos à Lesão Térmica. $140 \mathrm{f}$. Dissertação de Doutorado apresentado ao Instituto de Ciências Biomédicas. São Paulo, 2006.

OLUSI, S.O.; McFARLANE, H. Effects of Early Protein-Calorie Malnutrition on the Immune Response. Pediatr. Res., v. 10, p.707-712, 1976.

ONIS, M.; MONTEIRO, C.; AKRÉ, J.; CLUGSTON, G. The worldwide magnitude of protein-energy malnutrition: an overview from the WHO Global Database on Child Growth. Bull. World. Health Org., v. 71, n. 6, p. 703-712, 1993.

PARK, S.H.; KIM, H.K.; KIM, H.; RO, J.Y. Apoptosis in the thymic epithelial tumors. Pathol. Res. Pract., v. 198, p. 461-467, 2002.

PEARSE, G. Normal Structure, Function and Histology of the Thymus. Tox. Pathol., v. 34, p.504-514, 2006. 
PELLETIER, D.L.; Potentiating effects of malnutrition on child mortality: Epidemiologic evidence and policy implications. Food Nutr. Bull., v. 16, p. 206-13, 1995.

PICHARD, C. From protein-energy malnutrition to refeeding: more basic research is needed. Clin. Nutr., v. 16, n. 1, p. 1, 1997.

PIMSTONE, B.L.; BARBEZAT, G.; HANSEN, J.D.; MURRAY, P. Studies on Growth hormone secretion in Protein-Calorie Malnutrition. Am. J. Clin. Nutr. v. 21, n. 5, p.482487, 1968.

PRELOG, M. Aging of the immune system: A risk factor for autoimmunity? Autoimmun. Rev., v. 5, p. 136-139, 2006.

PRENTICE, A.M. The thymus: a barometer of malnutrition. Br. J. Nutr., v. 81, p. 345$347,1999$.

RAICA, M.; CIMPEAN, A.M.; ENCICÃ, S.; MOTOC, A. Lymphocyte-rich Hassall Bodies in the normal human thymus. Ann. Anat., v.187, p. 175-177, 2005.

RAICA, M.; ENCICÃ, S.; MOTOC, A.; CÎMPEAN, A.M.; SCRIDON, T.; BÂRSAN, M. Structural heterogeneity and immunohistochemical profile of Hassall corpuscles in normal human thymus. Ann. Anat., v. 188, p. 345-352, 2006.

REEVES, P.G.; NIELSEN, F.H.; FAHEY-Jr., G.C. AIN-93 Purified Diets for Laboratory Rodents: Final Report of the American Institute of Nutrition Ad Hoc Writing Committee on the Reformulation of the AIN-76A Rodent Diet. J. Nutr., v.123, p.1939-1951, 1993.

REVILLARD, J.P.; COZON, G. Experimental models and mechanisms of Immune deficiencies of Nutritional origin. Food Addit. Contam.,. v. 7, p. 82-86, 1990.

ROMANI, S.A.M; LIRA, P.I.C. Fatores determinantes do crescimento infantil. Rev. Bras. Saúde Matern. Infant., v. 4, n. 1, p. 15-23, 2004.

ROMEIS, B. Mikroskopische Technick. 6. ed. München, Oldenbourg, 1968.

SAVINO, W.; SANTA-ROSA,G.L. Histophysiology of Thymic Epithelial Reticular Cells. Arch. Histol. Jap., v. 45, n. 2, p. 139-144, 1982.

SAVINO, W.; LEITE DE MORAES, M.C.; HONTEBEYRIE-JOSKOWICZ, M.; DARDENNE, M. Studies on the thymus in Chagas disease I. Changes in the thymic microenviroment in mice acutely infected with Trypanosoma cruzi. Eur. J. Immunol., v. 19, p. 1727-1733, 1989.

SAVINO, W.; DARDENNE, M.; Neuroendocrine Control of Thymus Physiology. Endocrine Rev., v. 21, n. 4, p. 312-443, 2000. 
SAVINO, W. The Thymus is a Common Target Organ in Infectious Disease. PLoS Pathog., v. 2, n. 6, p. 472-483, 2006.

SAVINO, W.; DARDENNE, M.; VELLOSO, L.A.; SILVA-BARBOSA, S.D. The Thymus is a Common target in Malnutrition and Infection. Br. J. Nutr., v. 98, n. 1, p. 11-16, 2007.

SELLMEYER, E.; BHETTAY, E.; TRUSWELL, A.S.; MEYERS, O.L.; HANSEN, J.D.L. Lymphocite transplantation in malnourished children. Arch. Dis. Child., v. 47, p. 429435, 1972.

SHEZEN, E.; OKON, E.; BEN-HUR, H.; ABRAMSKY, O. Cytokeratin expression in human thymus: immunohistochemical mapping. Cell Tissue Res., v. 279, p. 221-231, 1995.

SCHOFIELD, C.; ASWORTH, A. Why have mortality rates for severe malnutrition remained so high? Bull. World Health Org. v. 74, p. 223-9, 1996.

SLOBODIANIK, N.H.; PALLARO, A.N.; ROUX, M.E.; RIO, M.E. Effects of low-quality dietary protein on the thymus of growing rats. Nutrition, v. 5, n. 6, p. 417-418, 1989.

STEINMANN, G.G.; KLAUS, B.; MÜLLER-HERMELINK, H.K. The involution of the ageing thymic epithelium is independent of puberty. Scand. J. Immunol., v. 22, p. 563575,1985

SUSTER, S.; ROSAI, J. Histology of the Normal Thymus. Am. J. Surg. Pathol., v. 14, n. 3, p. 284-303, 1990.

TRAININ, N.; KOOK, A.I.; UMIEL, T.; ALBALA, M. The nature and mechanism of immune responsiveness by the thymus extracts. Ann. New York Acad. Sci., v. 259, p. 349-361, 1975.

TRAININ, N.; ROTTER, V.; YAKIR, Y.; LOVE, R.; HANDZEL, Z.; SHOHAT, B.; ZAIZOV, R. Biochemical and biological properties of THF in animals and human models. Ann. New York Acad. Sci., v. 332, p. 9-22, 1979.

Van EWIJK, W.; WANG, B.; HOLLANDER, G.; KAWAMOTO, H.; SPANOPOULOU, E.; ITOI, M.; AMAGAI, T.; JIANG, Y.; GERMERAAD, W.T.V.; CHEN, W.; KATSURA, Y. Thymic microenvironments, 3-D versus 2-D? Immunology, v. 11, p. 57-64, 1999.

WATERLOW, J.C. Protein-energy malnutrition: the nature and extent of the problem. Clin. Nutr., v. 16, n. 1, p. 3-9, 1997.

WEIGERT, C. Ube reine methode zur forbung elastischer fasern. Zentbl. Allg. Pathol. Pathol. Anat., v. 9, p. 289-292, 1898.

WEINDRUCH, R.H.; SUFFIN, S.C. Quantitative Histologic effects on Mouse Thymus of Controlled Dietary Restriction. J. Geront., v. 35, n. 4, p. 525-531, 1980. 
WEISS, L. Electron Microscopic Observations on the vascular barrier in the cortex of the Thymus of the mouse. Anat. Rec., v. 145, p. 413-437, 1962

WORLD HEALTH ORGANIZATION. Joint FAO/WHO expert committee on nutrition, 6th report, WHO. Rep. Ser., n. 45, 1962.

VIAU V.; BINGHAM B.; DAVIS J.; LEE P.; WONG M. Gender and puberty interact on the stress-induced activation of parvocellular neurosecretory neurons and corticotrophin releasing hormone messenger ribonucleic acid expression in the rat. Endocrinology, $v$. 146. n. 1, p. 137-146, 2005.

ZAR, J.H. Bioestatistical analysis. 2. ed. N. Jersey: Prentice-Hall, 1984. 